JOINT TRANSPORTATION RESEARCH PROGRAM

FHWA/IN/JTRP-2010/5

Final Report

DETERMINATION OF UNIT HYDROGRAPH

PARAMETERS FOR INDIANA WATERSHEDS

Jared L. Wilkerson

Venkatesh M. Merwade

September 2010 


\section{TECHNICAL Summary}

Technology Transfer and Project Implementation Information

INDOT Research

TRB Subject Code:23-6 Erosion and Water Pollution Control

Publication No.FHWA/IN/JTRP-2010/5, SPR-3226

September 2010

Final Report

\section{Determination of Unit Hydrograph Parameters for Indiana Watersheds}

\section{Introduction}

Natural Resources Conservation Service's (NRCS) dimensionless unit hydrograph method is one of the most commonly used synthetic unit hydrograph (SUH) techniques to predict hydrographs for ungauged basins in Indiana. Application of NRCS method in Indiana yields very high peak flows and short time to peaks for the northern region, thus producing unrealistic flow estimates for design purposes. On the other hand, the hydrograph predictions in the southern region match well with measured streamflow. It is hypothesized that the overestimation of peak flows in northern region using SCS method is due to the flat terrain and relatively higher surface storage caused by the Wiconsinan glaciations. To incorporate the slope and storage characteristics, the application of Clark SUH, which incorporates time of concentration and a storage parameter to produce runoff hydrograph, is explored for Indiana.

\section{Findings}

Northern and central Indiana are geomorphologically different from the southern region. Statistical analysis has shown a significant difference in the hydrology and geomorphology of northern Indiana compared to the southern region. It has been shown that watersheds in southern Indiana have statistically significantly higher slopes and peak flow rates. Also, northern Indiana's hydrology is affected by increased depression storage and lower slopes, and as a result has lower peak flows and increased times to peak. The central region appears to be a transition between the two geomorphologic extremes of the other two regions. These characteristics can be accounted for using SUH methods.

The Clark SUH Method has been shown to account for the effects of low slopes and high depression storage using the parameters tc and $\mathrm{R}$. The Clark SUH parameters can be estimated using geomorphologic parameters extracted using GIS tools. GIS techniques can improve the accuracy and ease of geomorphologic parameter extraction. Multiple linear regression can then be utilized to establish statistically significant relationships between the geomorphologic parameters and the Implementation
Clark SUH parameters tc and R. Comparisons of the Clark and NRCS SUH methods show that the former's flexibility to incorporate varying of geomorphology and adjust the hydrograph's shape accordingly. In this manner the regression equations can extend the estimation of the Clark SUH parameters to ungauged watersheds of similar hydrology and geomorphology in Indiana.

The strength of these regression equations is their ease of use. Utilizing current GIS technology has become the standard in many hydrologic modeling applications. Geomorphologic parameters can be extracted accurately and quickly. Also, the regression equations can provide statistical information regarding confidence limits and measurable error of the Clark SUH parameter estimates. It is important to keep in mind, with any hydrologic method, an investigation into the results using this method is necessary before use in any design or modeling application. Comparison of this method with current established modeling methods is advised. Also, the regression equations should be applied only to watersheds with geomorphologic characteristics within the ranges used in this study. 
Deriving geomorphic parameters (independent variables) for watersheds using the tutorial provided in Appendix G of the report.
Setting-up an Excel Sheet to estimate Clark SUH parameters using geomorphic parameters derived through the procedure in Appendix G.

\section{Contacts}

For more information:

Prof. Venkatesh Merwade

Principal Investigator

School of Civil Engineering

Purdue University

West Lafayette IN 47907

Phone: (765) 494-2176

E-mail: vmerwade@purdue.edu
Office of Research \& Development 1205 Montgomery Street

P.O. Box 2279

West Lafayette, IN 47906

Phone: (765) 463-1521

Fax: (765) 497-1665

Purdue University

Joint Transportation Research Program

School of Civil Engineering

West Lafayette, IN 47907-1284

Phone: (765) 494-9310

Fax: (765) 496-7996

E-mail: jtrp@ecn.purdue.edu

http://www.purdue.edu/jtrp 
Final Report

FHWA/IN/JTRP-2010/5

\title{
DETERMINATION OF UNIT HYDROGRAPH PARAMETERS FOR INDIANA \\ WATERSHEDS
}

\author{
By \\ Jared L. Wilkerson \\ Graduate Research Assistant \\ Venkatesh M. Merwade, PhD \\ Professor \\ Joint Transportation Research Program \\ Project No. C-36-62V \\ File No. 9-8-22 \\ SPR 3226 \\ Conducted in cooperation with the \\ Indiana Department of Transportation \\ and the \\ U.S. Department of Transportation \\ Federal Highway Administration
}

The contents of this report reflect the views of the author, who are responsible for the facts and the accuracy of the data presented herein. The contents do not necessarily reflect the official views or policies of the Indiana Department of Transportation or the Federal Highway Administration at the time of publication. This report does not constitute a standard, specification, or regulation.

\footnotetext{
Purdue University

West Lafayette, IN 47907
}

September 2010 


\begin{tabular}{|c|c|c|}
\hline $\begin{array}{l}\text { 1. Report No. } \\
\text { FHWA/IN/JTRP-2010/5 }\end{array}$ & 2. Government Accession No. & 3. Recipient's Catalog No. \\
\hline \multirow{2}{*}{\multicolumn{2}{|c|}{$\begin{array}{l}\text { 4. Title and Subtitle } \\
\text { Determination of Unit Hydrograph Parameters for Indiana Watersheds }\end{array}$}} & $\begin{array}{l}\text { 5. } \quad \text { Report Date } \\
\text { September } 2010\end{array}$ \\
\hline & & 6. Performing Organization Code \\
\hline \multicolumn{2}{|c|}{$\begin{array}{l}\text { 7. Author(s) } \\
\text { Jared L. Wilkerson and Venkatesh M. Merwade }\end{array}$} & $\begin{array}{l}\text { 8. Performing Organization Report No. } \\
\text { FHWA/IN/JTRP-2010/5 }\end{array}$ \\
\hline \multirow{2}{*}{\multicolumn{2}{|c|}{$\begin{array}{l}\text { 9. Performing Organization Name and Address } \\
\text { Joint Transportation Research Program } \\
\text { 1284 Civil Engineering Building } \\
\text { Purdue University } \\
\text { West Lafayette, IN 47907-1284 }\end{array}$}} & 10. Work Unit No. \\
\hline & & $\begin{array}{l}\text { 11. Contract or Grant No. } \\
\text { SPR-3226 }\end{array}$ \\
\hline \multirow{2}{*}{\multicolumn{2}{|c|}{$\begin{array}{l}\text { 12. Sponsoring Agency Name and Address } \\
\text { Federal Highway Administration } \\
575 \text { N. Pennsylvania, Room } 254 \\
\text { Indianapolis, IN } 46204\end{array}$}} & $\begin{array}{c}\text { 13. Type of Report and Period Covered } \\
\text { Final Report }\end{array}$ \\
\hline & & 14. Sponsoring Agency Code \\
\hline
\end{tabular}

15. Supplementary Notes

Prepared in cooperation with the Federal Highway Administration and the Indiana Department of Transportation.

\section{Abstract}

Regression equations predicting Clark Synthetic Unit Hydrograph (SUH) parameters for time of concentration (tc)

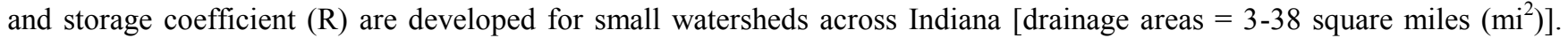
The state is partitioned into three regions: North, Central, and South, with consideration for past regionalization studies of Indiana and geomorphology. The equations are derived using multiple linear regression analysis for 30 watersheds with 90 observed rainfall-runoff events. Clark SUH parameters are optimized using Hec-HMS to match the observed rainfall-runoff events. The optimized Clark SUH parameters are related to geomorphologic parameters estimated using geographic information system (GIS) applications. An extensive list of 29 geomorphologic parameters is considered including parameters related to depression storage, slope, drainage area, basin shape, and stream network. Separate regression equations for tc and $\mathrm{R}$ are developed for each region and the entire state. Values for $t_{c}$ and $\mathrm{R}$ are predicted using the regression equations and used to model 7 new rainfall-runoff events in HEC-HMS for comparison to the NRCS SUH method.

.

17. Key Words

Synthetic Unit Hydrograph; Clark Synthetic Unit Hydrograph; NRCS Unit Hydrograph; Geomorphic Parameters; Watershed Storage; Slope; Linear Regression.
18. Distribution Statement

No restrictions. This document is available to the public through the National Technical Information Service, Springfield, VA 22161
19. Security Classif. (of this report)

Unclassified
20. Security Classif. (of this page)

Unclassified
21. No. of Pages

114 


\section{ACKNOWLEDGMENTS}

I would like to extend sincere gratitude to the many people that provided guidance and assistance which made this thesis possible. Special thanks is due to Dr. Venkatesh Merwade for his guidance and service as my advisor. His experience and knowledge of GIS applications in hydrologic modeling were invaluable to the success of my research. Gratitude is due to Don Arvin (USGS) and David Knipe (IDNR) for providing data that was essential to this research. Furthermore, gratitude is owed to the Study Advisory Committee for their participation and advice during our meetings throughout this project. I would also like to thank Dr. Rao Govindaraju and Dr. Dennis Lynn for their service on my committee.

Purdue University provided funding for my graduate research through the Joint Transportation Research Program (JTRP). I would like to thank everyone involved with the JTRP for allowing me the opportunity to pursue a master's degree at Purdue University and work on a project in service of the state of Indiana. 


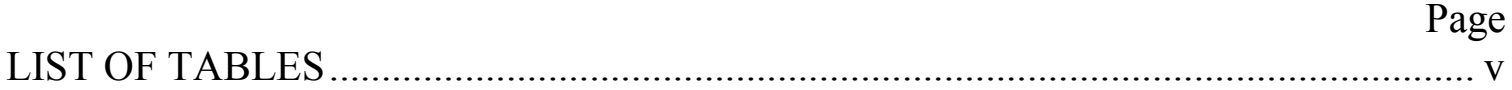

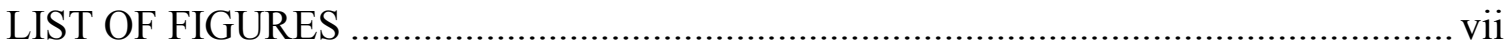

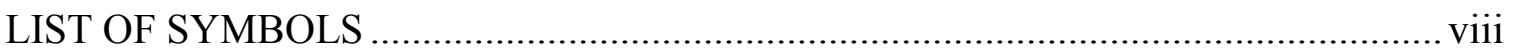

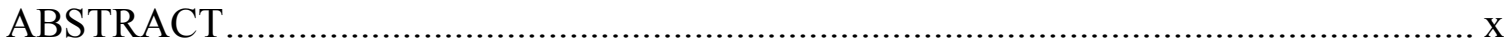

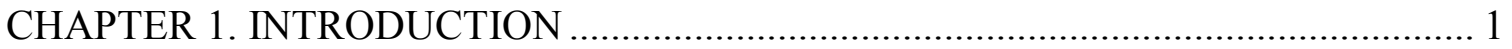

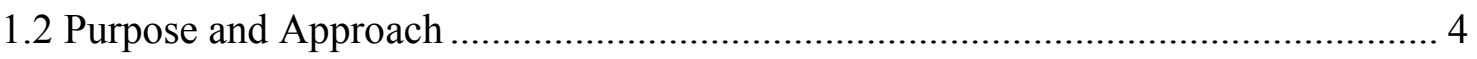

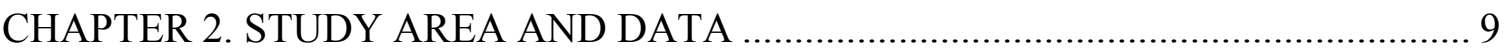

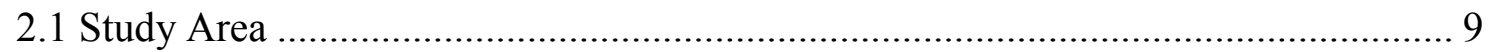

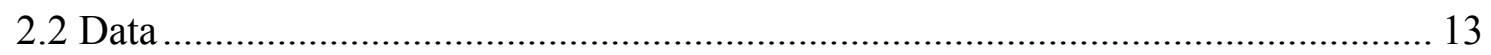

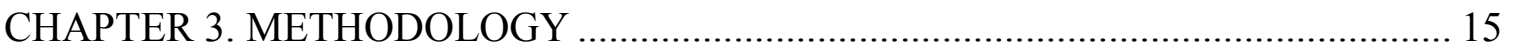

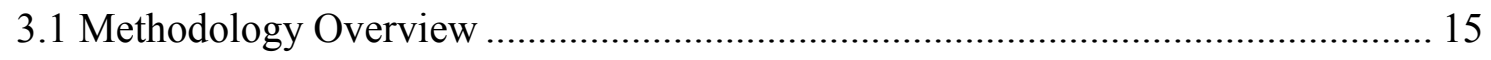

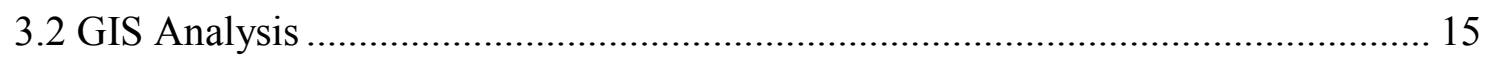

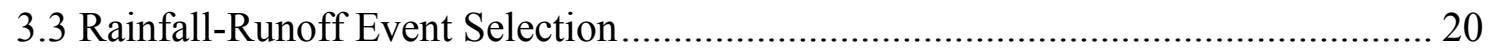

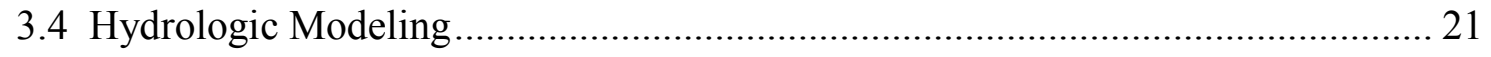

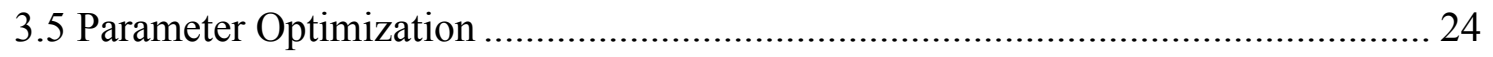

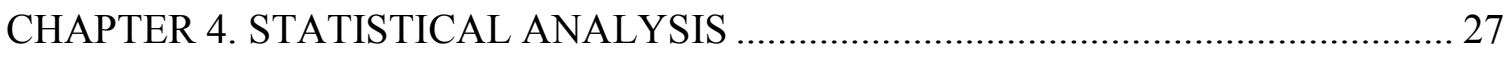

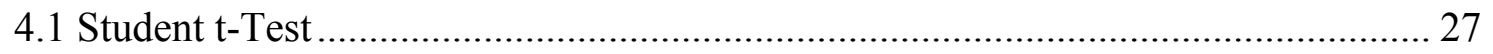

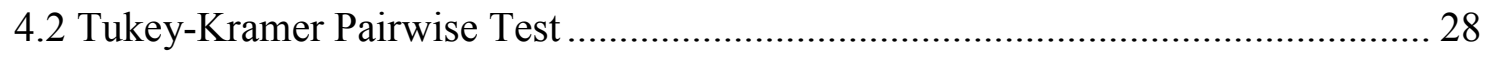

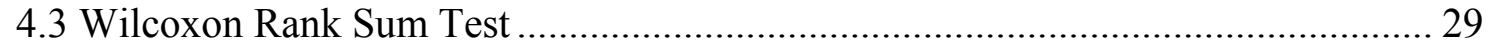

CHAPTER 5. DEVELOPMENT OF REGIONAL REGRESSION EQUATIONS........ 30

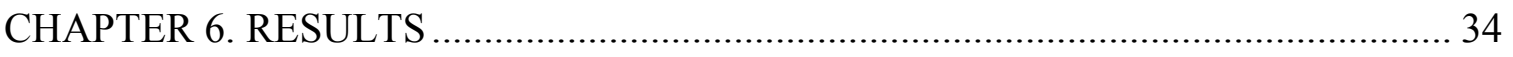

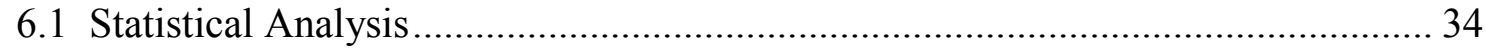

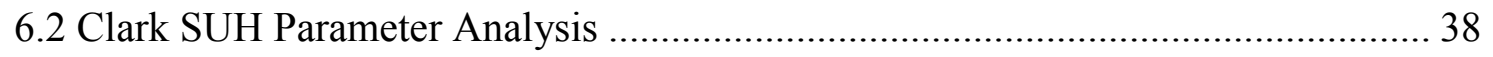

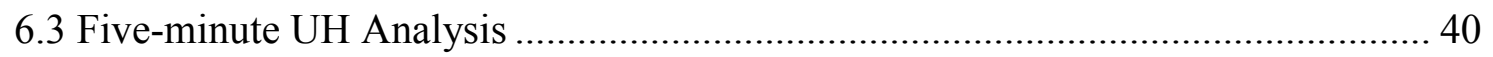

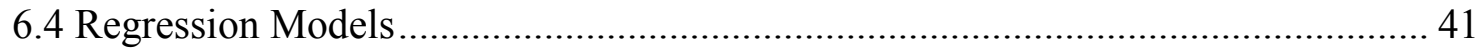

6.5 Regression Models - North Region ................................................................. 42

6.6 Regression Models - Central Region .................................................................. 43 


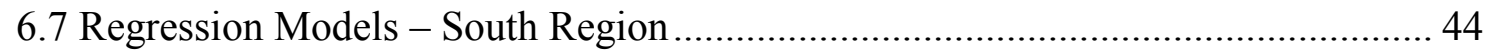

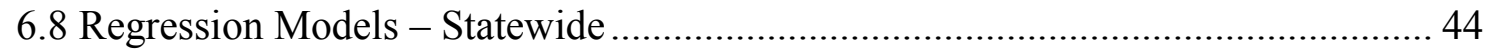

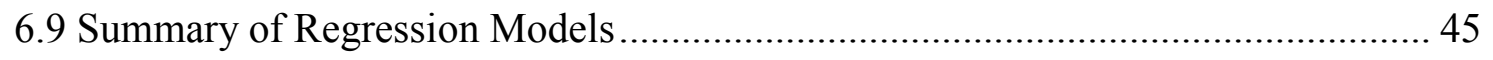

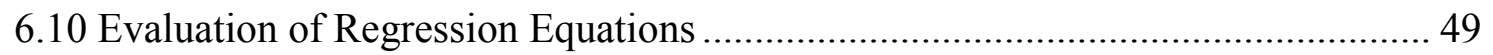

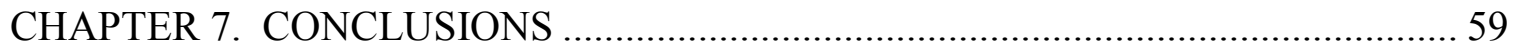

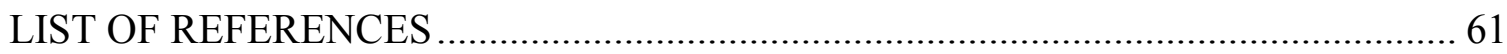

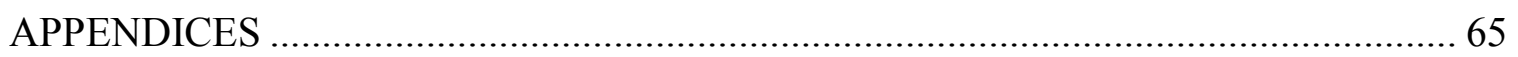

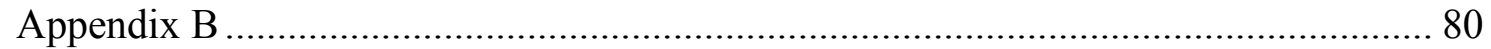

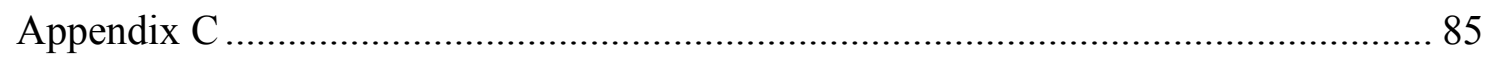

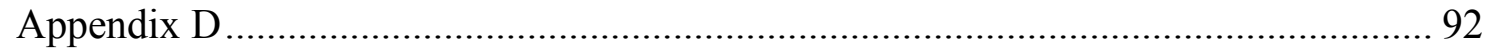

Correlation tables for all variables in Tables D.1. - D.3 ............................................ 92

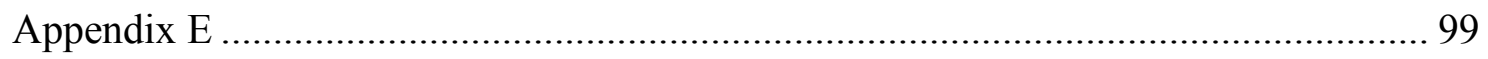

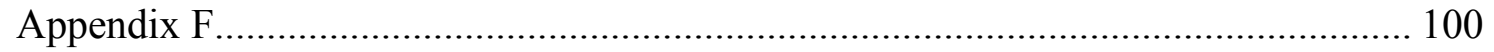

Appendix G: Link to Tutorials for Measuring Geomorphologic Parameters .............. 102 


\section{LIST OF TABLES}

Table

Page

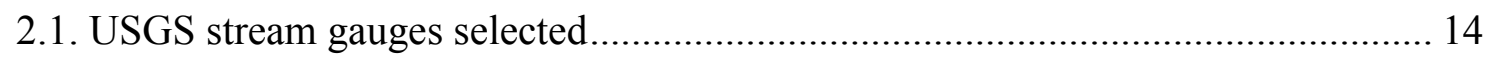

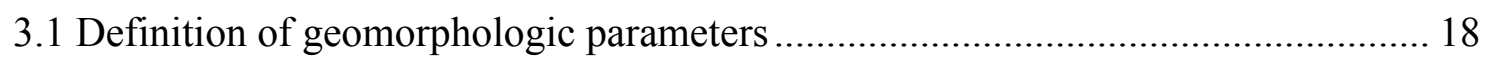

3.2. Definition of additional geomorphological parameters .......................................... 19

6.1. Results of statistical analysis of geomorphologic parameters ............................... 35

6.2. Summary of Optimized Clark SUH parameters ................................................... 39

6.3. Summary of best Northern Region regression equations. ...................................... 42

6.4. Summary of best Central Region regression equations.......................................... 43

6.5. Summary of best South Region regression equations............................................. 44

6.6. Summary of best Statewide regression equations................................................... 45

6.7. Regression equations selected for implementation................................................ 47

6.8. Study areas selected for implementation ............................................................ 49

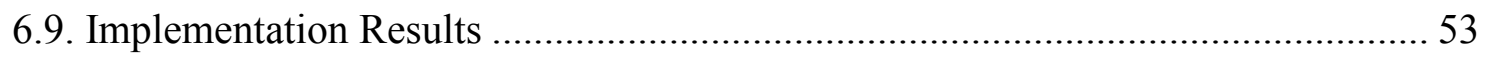

6.10. Calculated and Optimized Clark values................................................................ 54

A.1. Scenario 1- Log Transformed R Regression for North Region .............................. 65

A.2. Linear Model - Scenerio 2 R Regression for North Region ................................... 66

A.3. Log Model $1-$ Scenerio $1 t_{c}$ Regression for North Region .................................... 67

A.4. Log Model 1 - Scenerio 2 tc Regression for North Region.................................... 68 
A.5. Log Model 1 - Scenerio 1 R Regression for Central Region ............................. 69

A.6. Square Root Model 1 - Scenerio 2 R Regression for Central Region ................... 70

A.7. $\log$ Model $1-$ Scenerio $1 t_{c}$ Regression for Central Region.............................. 71

A.8. Log Model 1 - Scenerio $2 t_{c}$ Regression for Central Region.............................. 72

A.9. Log Model 1 - Scenario 1 R Regression for South Region................................. 73

A.10. Log Model 1 - Scenario 1 tc Regression for South Region............................... 74

A.11. Log Model 1 - Scenario 2 R Regression for South Region ............................. 75

A.12. Log Model 1 - Scenario 2 R Regression for State....................................... 76

A.13. Log Model 1 - Scenario 2 tc Regression for State ....................................... 78

B.1. Extracted Geomorphologic Parameters $\ldots \ldots \ldots \ldots \ldots \ldots \ldots \ldots \ldots \ldots \ldots \ldots \ldots \ldots . \ldots 1$

C.1. Stepwise Selection for Linear Model R ...................................85

C.2. Stepwise Selection for Logarithmic Model R .............................. 87

C.3. Stepwise Selection for Square Root Model R..............................88

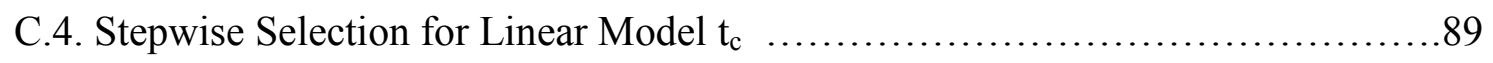

C.5. Stepwise Selection for Logarithmic Model $t_{c} \ldots \ldots \ldots \ldots \ldots \ldots \ldots \ldots \ldots \ldots \ldots \ldots$

C.6. Stepwise Selection for Square Root Model $t_{c} \ldots \ldots \ldots \ldots \ldots \ldots \ldots \ldots \ldots \ldots \ldots . \ldots 1$

D.1. Correlation Matrix for North Region Variables ............................93

D.2. Correlation Matrix for Central Region Variables $\ldots \ldots \ldots \ldots \ldots \ldots \ldots \ldots \ldots \ldots . . . . \ldots 5$

D.3. Correlation Matrix for South Region Variables ...........................97

E.1. Range of Geomorphologic Parameters for Regression Equations ................99

F.1. Precipitation Depth and Duration......................................................... 100 


\section{LIST OF FIGURES}

Figure

Page

1.1. Illustration of NRCS Method for three watersheds ......................................... 5

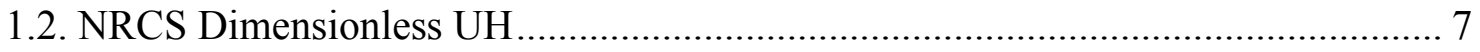

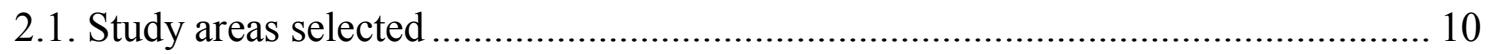

2.2. Southern border of Wisconsinan Glaciation ................................................. 12

6.1-6.6. Box Plots displaying slope related geomorphologic parameters ................... 36

6.7-6.10. Box plots displaying other significant geomorphologic parameters ............. 37

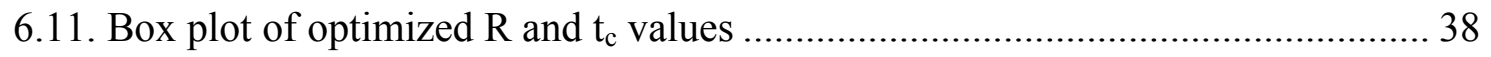

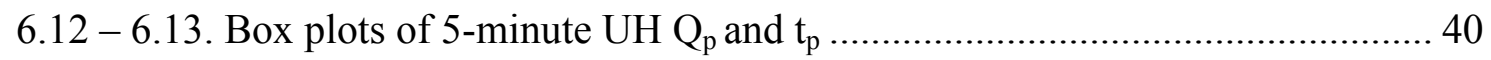

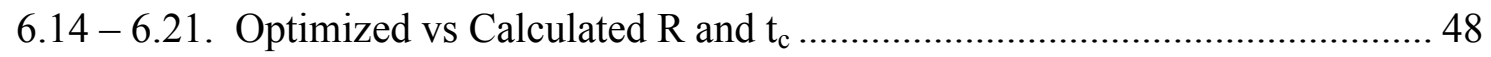

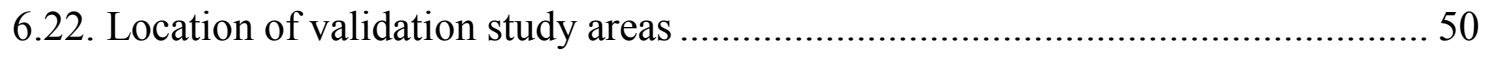

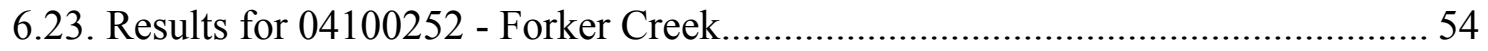

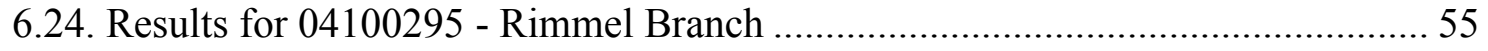

6.25. Results for 05521000 - Iroqouis River ................................................. 55

6.26. Results for 03333600 - Kokomo Creek.................................................... 56

6.27. Results for 03353637 - Little Buck Creek ...................................................... 56

6.28. Results for 03302680 - West Fork Blue River .............................................. 57

6.29. Results for 03375800 - Hall Creek.............................................................. 58 


\section{LIST OF SYMBOLS}

\begin{tabular}{|c|c|}
\hline $\mathrm{A}_{\mathrm{w}}$ & drainage area \\
\hline $\mathrm{C}$ & constant of channel maintenance \\
\hline $\mathrm{CDA}$ & contributing drainage area \\
\hline $\mathrm{C}_{\mathrm{f}}$ & stream frequency \\
\hline $\mathrm{CN}$ & curve number \\
\hline $\mathrm{D}$ & drainage density \\
\hline G & Gray's geomorphologic parameter \\
\hline $\mathrm{H}$ & basin relief \\
\hline HKR & Hickok's geomorphologic parameter \\
\hline $\mathrm{L}_{\mathrm{b}}$ & basin length \\
\hline $\mathrm{L}_{\mathrm{ca}}$ & length from the basin outlet to a point adjacent to the centroid \\
\hline $\mathrm{L}_{\mathrm{s}}$ & average grid slope \\
\hline M & Murphy's geomorphologic parameter \\
\hline $\mathrm{MCh}$ & main channel length \\
\hline $\mathrm{Q}_{\mathrm{p}}$ & peak flow rate \\
\hline $\mathrm{R}$ & Clark storage coefficient \\
\hline
\end{tabular}




$\begin{array}{ll}\mathrm{R}_{\mathrm{c}} & \text { circulatory ratio } \\ \mathrm{R}_{\mathrm{e}} & \text { elongation ratio } \\ \mathrm{R}_{\mathrm{f}} & \text { fineness ratio } \\ \mathrm{R}_{\mathrm{ff}} & \text { form factor } \\ \mathrm{R}_{\mathrm{h}} & \text { relief ratio } \\ \mathrm{R}_{\mathrm{n}} & \text { ruggedness number } \\ \mathrm{R}_{\mathrm{p}} & \text { relative relief } \\ \mathrm{R}_{\mathrm{u}} & \text { unity shape factor } \\ \mathrm{S}_{\mathrm{b}} & \text { basin shape factor } \\ \mathrm{Slope} & \text { 10-85\% slope } \\ \mathrm{t}_{\mathrm{c}} & \text { Clark time of concentration } \\ \mathrm{t}_{\mathrm{p}} & \text { time to peak flow rate } \\ \mathrm{ULC} \% & \text { urban land cover } \\ \mathrm{Water} & \text { \% water or wetland } \\ & \end{array}$




\begin{abstract}
Jared L. Wilkerson. M.S.C.E., Purdue University, May 2009. Regional Regression Equations to Estimate Synthetic Unit Hydrograph Parameters for Indiana.

Major Professor: Venkatesh Merwade
\end{abstract}

Regression equations predicting Clark Synthetic Unit Hydrograph (SUH) parameters for time of concentration $\left(t_{c}\right)$ and storage coefficient $(R)$ are developed for small watersheds across Indiana [drainage areas $=3-38$ square miles $\left.\left(\mathrm{mi}^{2}\right)\right]$. The state is partitioned into three regions: North, Central, and South, with consideration for past regionalization studies of Indiana and geomorphology. The equations are derived using multiple linear regression analysis for 30 watersheds with 90 observed rainfall-runoff events. Clark SUH parameters are optimized using HEC-HMS to match the observed rainfall-runoff events. The optimized Clark SUH parameters are related to geomorphologic parameters estimated using geographic information system (GIS) applications. An extensive list of 29 geomorphologic parameters is considered including parameters related to depression storage, slope, drainage area, basin shape, and stream network. Separate regression equations for $t_{c}$ and $\mathrm{R}$ are developed for each region and the entire state. Values for $\mathrm{t}_{\mathrm{c}}$ and $\mathrm{R}$ are predicted using the regression equations and used to model 7 new rainfall-runoff events in HEC-HMS for comparison to the NRCS SUH method. 


\section{CHAPTER 1. INTRODUCTION}

Synthetic unit hydrograph methods are utilized to determine runoff hydrographs for ungauged sites. The runoff hydrograph is important in designing stormwatermanagement infrastructure such as culverts and detention facilities. Analysis of the hydrologic effects of bridge contractions and flood-plain assessment also rely on the use of runoff hydrographs. These runoff hydrographs are computed using design storm events based on probability of occurrence determined from references such as Bulletin 71 (Huff and Angel 1992) and National Oceanic and Atmospheric Administration (NOAA) Atlas 14 (Bonin et al. 2004). Once the proper design storm is selected, abstractions due to depression storage, interception, and infiltration must be separated from total precipitation. Typically this is done using parameters that incorporate soil types, land cover/land use, and antecedent moisture conditions. The National Resources Conservation Service (NRCS) method is the best example. A standardized curve number is applied based on antecedent moisture conditions, hydrologic soil group, and land cover/land use. The curve number is used to partition rainfall into losses and excess precipitation. The excess precipitation is then transformed into a runoff hydrograph using the traditional unit hydrograph or some other synthetic transform method. 
The unit hydrograph (UH) theory was first introduced by Sherman (1932) using superposition to predict hydrographs from observed rainfall and runoff data rather than just peak discharges. The $\mathrm{UH}$ is the hydrograph resulting from 1 unit of excess precipitation. UHs are defined for a particular watershed and calculated as the runoff hydrograph resulting from one unit of excess precipitation. Excess precipitation is the precipitation not lost to depression storage or infiltration (Chow et al. 1988). The traditional UH however is only useful for gauged sites. Synthetic unit hydrographs (SUH) are a way to extend the use of UH theory to ungauged watersheds (Jena et al. 2006). SUHs are used to establish the UH for an ungauged watershed. Snyder (1938) was the first to develop a synthetic unit hydrograph method that tried to relate measured geomorphologic characteristics to unit hydrograph parameters. Snyder's study of watersheds in the Appalachian Mountains related values for time to peak to watershed length, distance from watershed centroid to the outlet, and a regional coefficient. Peak flow rate was computed using watershed area, time to peak, and a storage coefficient (Jena et al. 2006).

Clark (1945) developed his own SUH method that incorporated a parameter to model the watershed storage $(\mathrm{R})$ and time of concentration $\left(\mathrm{t}_{\mathrm{c}}\right)$. The Clark SUH Method incorporates the processes of attenuation and translation of runoff through the use of the time-area curve. Clark (1945) noted the translation of flow through the watershed was described by a time-area curve that expresses the fraction of watershed area contributing runoff to the watershed outlet as a function of time since the start of effective precipitation (Straub et al. 2000). A linear reservoir was used by Clark to 
reflect the storage effects of watersheds. Clark's method attempts to relate geomorphologic properties to watershed response using time-related parameters.

A geomorphologic unit hydrograph $(\mathrm{GUH})$ was presented by Rodriquez-Itrube and Valdes (1979) and Gupta et al. (1980). Their aim was to parametrize the hydrographs in terms of geomorphology, specifically using Horton's bifurcation ratio, stream length ratio, and stream area ratio (Cleveland 2008). Jin (1992) developed a GUH utilizing a gamma distribution based on similar geomorphology as in the Rodriquez-Itrube (1979) and Gupta et al. (1980) studies.

All of these SUH studies attempt to link distance, velocity, and time to physical characteristics of watersheds to infer a unit hydrograph in the absence of observed rainfall and runoff data. Currently studies utilizing geographic information systems (GIS) have developed parallel to GUH theory by incorporating similar ideas to relate the physical characteristics of watersheds to a GUH. A study by Shamseldin and Nash (1998) argues that GUH theory is equivalent to the assumption of a generalized UH equation described by a distribution whose parameters are related by regression to appropriate watershed characteristics (Cleveland 2008). This paper presents the results using the Clark SUH method whose parameters are related to the geomorphology of Indiana. 


\subsection{Purpose and Approach}

The application of the NRCS UH in Indiana has typically yielded accurate results for the steeper watersheds in southern Indiana, but tends to over estimate peak discharges for watersheds in the northern part of the state (Figure 1.1).
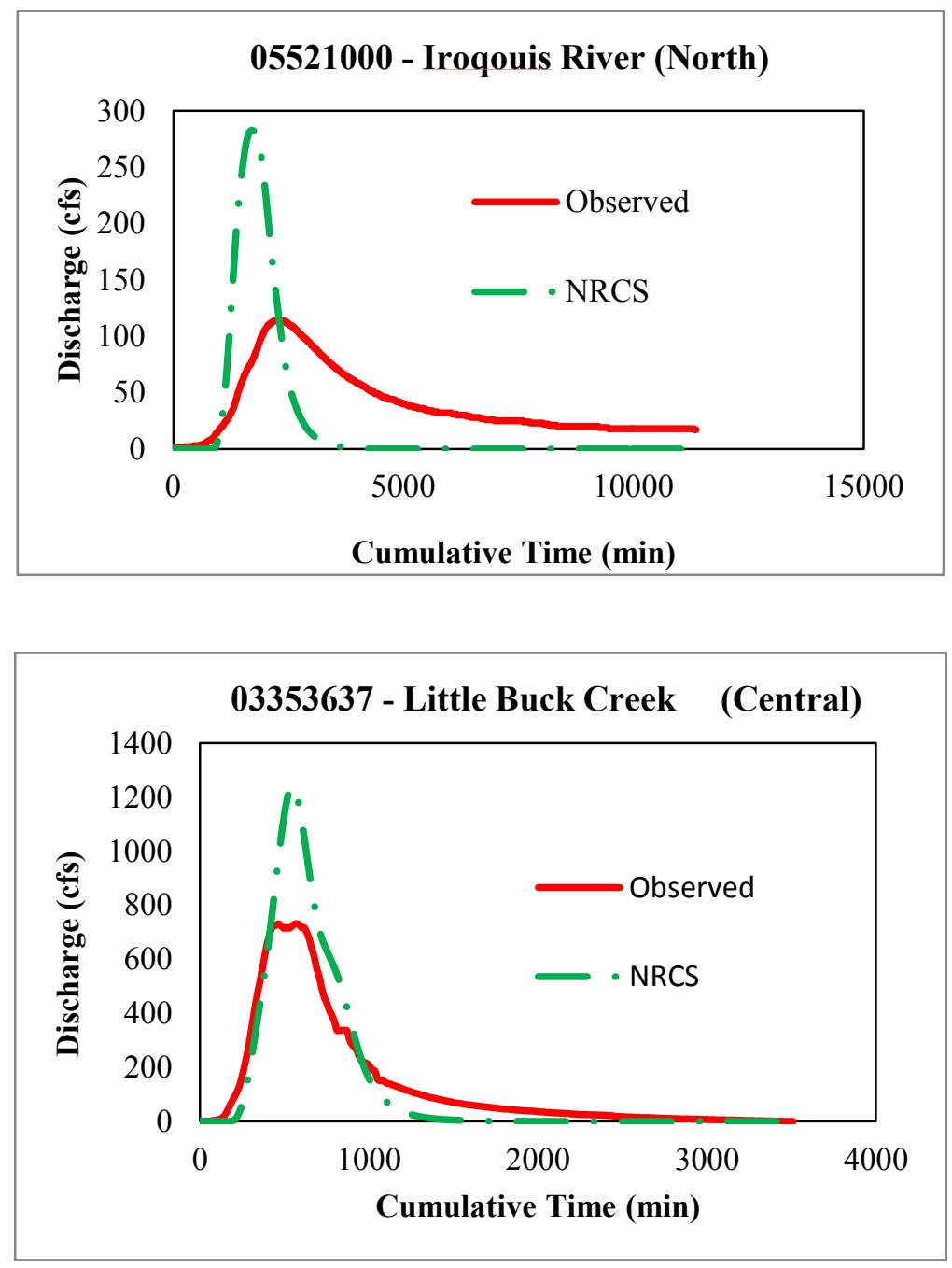


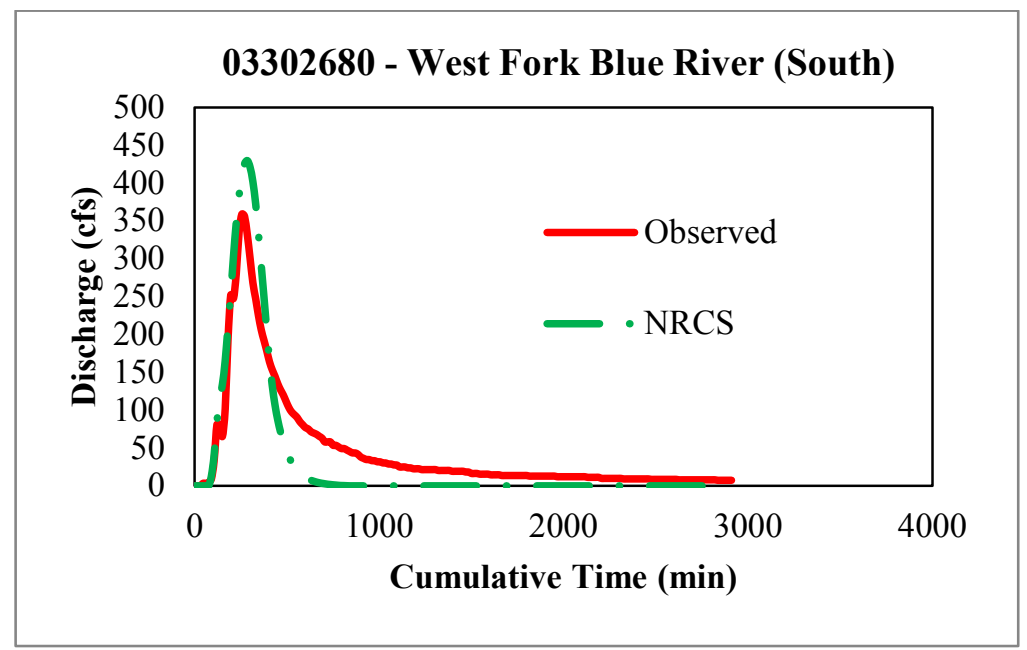

Figure 1.1. Illustration of NRCS Method for three watersheds

The assumption is that the lower gradient watersheds of northern Indiana have lower peak discharges as a result of greater watershed storage and longer travel times for runoff making it necessary to investigate the regional geomorphological characteristics throughout Indiana and how they relate to UH shape. The geomorphology of Indiana is discussed further in the next section. The NRCS UH is one of the most widely used SUHs and is incorporated in the TR-20 program. The NRCS dimensionless unit hydrograph was developed from the analysis of measured data for watersheds across the United States. The UHs were made dimensionless by dividing discharge ordinates by peak discharge and time ordinates by time to peak. NRCS (1985) curve number method is used to quantify watershed characteristics for rainfall abstractions, and to subsequently compute a runoff hydrograph for ungauged sites. The curve number approach is one of the most widely used SUH methods because of its ability to incorporate land cover/land-use characteristics. The Soil Conservation Service (now the NRCS) conducted research (SCS 1985) in which UHs 
for a wide variety of streams across the United States were averaged to form a composite UH that has become one of the most widely used methods for computing design runoff hydrographs.

A weakness of the NRCS method is the fixed hydrograph shape (Figure 1.2). With the NRCS, only the lag time and watershed area are used to control both the peak discharge and time base, meaning the rising and recession of the hydrograph remain the same relative to each other from one watershed to another. Alternatively the Clark SUH and traditional UH are dependent on geomorphology. The traditional UH method is very useful and flexible, but observed runoff data are necessary to establish the ordinates of the traditional UH for a given watershed. Thus, the traditional UH is not useful for application with ungauged watersheds. The Clark SUH method uses time of concentration and a storage coefficient to establish the shape of the time-area function used to establish the shape of the Clark SUH. The added flexibility of Clark SUH makes it a more capable method for relating geomorphology to hydrograph shape. Although the Clark SUH doesn't have the flexibility of the traditional UH method, it has the advantage of being a SUH and therefore applicable to ungauged watersheds. 


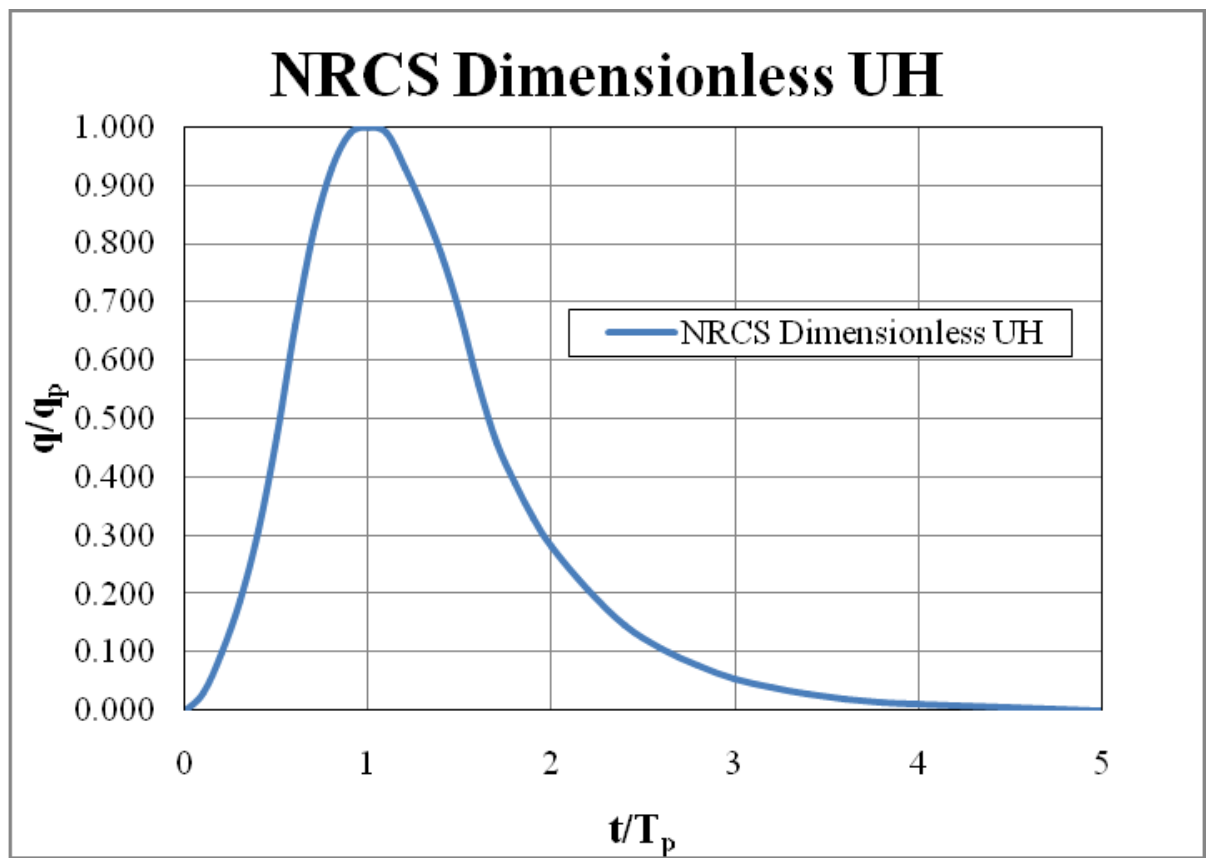

Figure 1.2. NRCS Dimensionless UH

All of the previously mentioned SUH methods attempt to extend the use of unit hydrograph theory to ungauged watersheds through the use of regional coefficients or parameters that describe watershed geomorphology. Other research attempting to more directly relate geomorphology to SUH parameters has been conducted by Hickok et al. (1959) and Gray (1961) for small watersheds in the west and midwestern United States. Research conducted by Rodriguez-Iturbe and Valdes (1979) showed how hydrograph structure is directly related to watershed geomorphology. However their research comparing GUH parameters to geomorphologic characteristics has involved using maps and instruments to measure landform and basin parameters, which may not be accurate due to human and instrument error. Because of the difficulty in measuring basin characteristics a minimum number of parameters were used in their regression models. Presently, the use of GIS software and available remote sensing and 
topographic information make estimating geomorphologic parameters much faster and accurate. (Jena et al. 2006). This would make GIS the preferred method for extracting watershed characteristics because a much larger list of geomorphologic characteristics could be utilized for estimating SUH parameters. Relating easily available geomorphologic characteristics using regression equations to the SUH parameters would give engineers a better way to calculate the necessary SUH parameters for both gauged and ungauged watersheds. Once the regression equations have been validated, the SUH parameters can be reliably estimated for use in the design of hydraulic structures. 


\section{CHAPTER 2. STUDY AREA AND DATA}

\subsection{Study Area}

In an attempt to gain insight into the important geomorphologic characteristics that result in varied hydrologic responses across the state, this study was undertaken on thirty small watersheds in Indiana. Methods for estimating flood flows for larger watersheds in Indiana have been described in studies by Knipe and Rao (2004), Glatfelter (1984), and Davis (1974). The present study focused on the smallest possible watersheds with observed streamflow data. Ten watersheds from corresponding United States Geologic Survey (USGS) stream gages were selected from each of the north, central, and southern regions of the state (Figure 2.1). Indiana is located in the midwestern region of the United States, lying within $37^{\circ} 46^{\prime}-41^{\circ} 46^{\prime}$ north latitude and $84^{\circ} 47^{\prime}-88^{\circ} 6^{\prime}$ west longitude. Indiana's elevation mainly lies between 150 and $300 \mathrm{~m}$ (500 to $1,000 \mathrm{ft}$ ) above sea level. Northern Indiana is home to many natural lakes created by the last glacial period which has left the topography of this region very flat. Central Indiana features some gently rolling hills and sandstone ravines. The central region is also characterized by a patch work of fields and forests. These two regions (north and central) were covered by glacial ice during the Wisconsinan glaciations (Figure 2.2) which left behind soil comprised of sand, clay and 


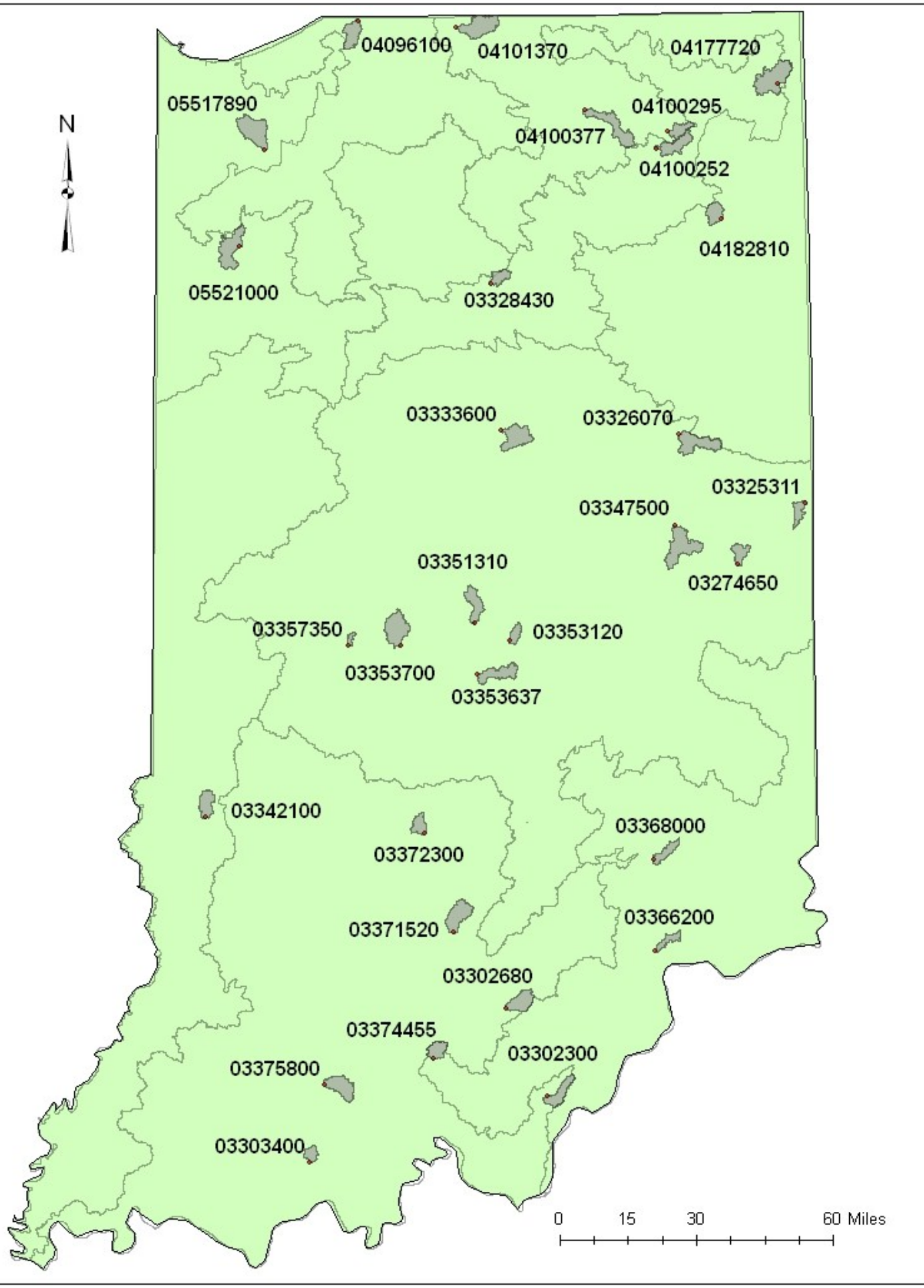

Figure 2.1. Study areas selected 
gravel called glacial till. Southern Indiana is a mixture of farmland, forests, and very hilly areas (especially near Louisville, KY). Southern Indiana's topography is more varied than the north and contains more hills and geographic variation due to the "Knobs", a series of hills that run parallel to the Ohio River. The southern region of Indiana has been more significantly reworked by natural forces such as erosion because it has not been glaciated since the Illinoisan period. The area is also known for its karst landscape that has resulted in the creation of many caves and one of the largest limestone quarry areas in the USA. Because the northern two-thirds of the state was covered by glaciers during the Wisconsinan glaciations, southern Indiana was exposed to the forces of erosion longer and more distinct river valleys (in comparison to the rest of the state) were carved by the large amounts of melting ice once the Wisconsinan glaciations began to recede. Figure 2.2 is a digital elevation model (DEM) displaying the southern boundary of the Wisconsinan glaciations. It is visually apparent that southern Indiana has steeper slopes. 


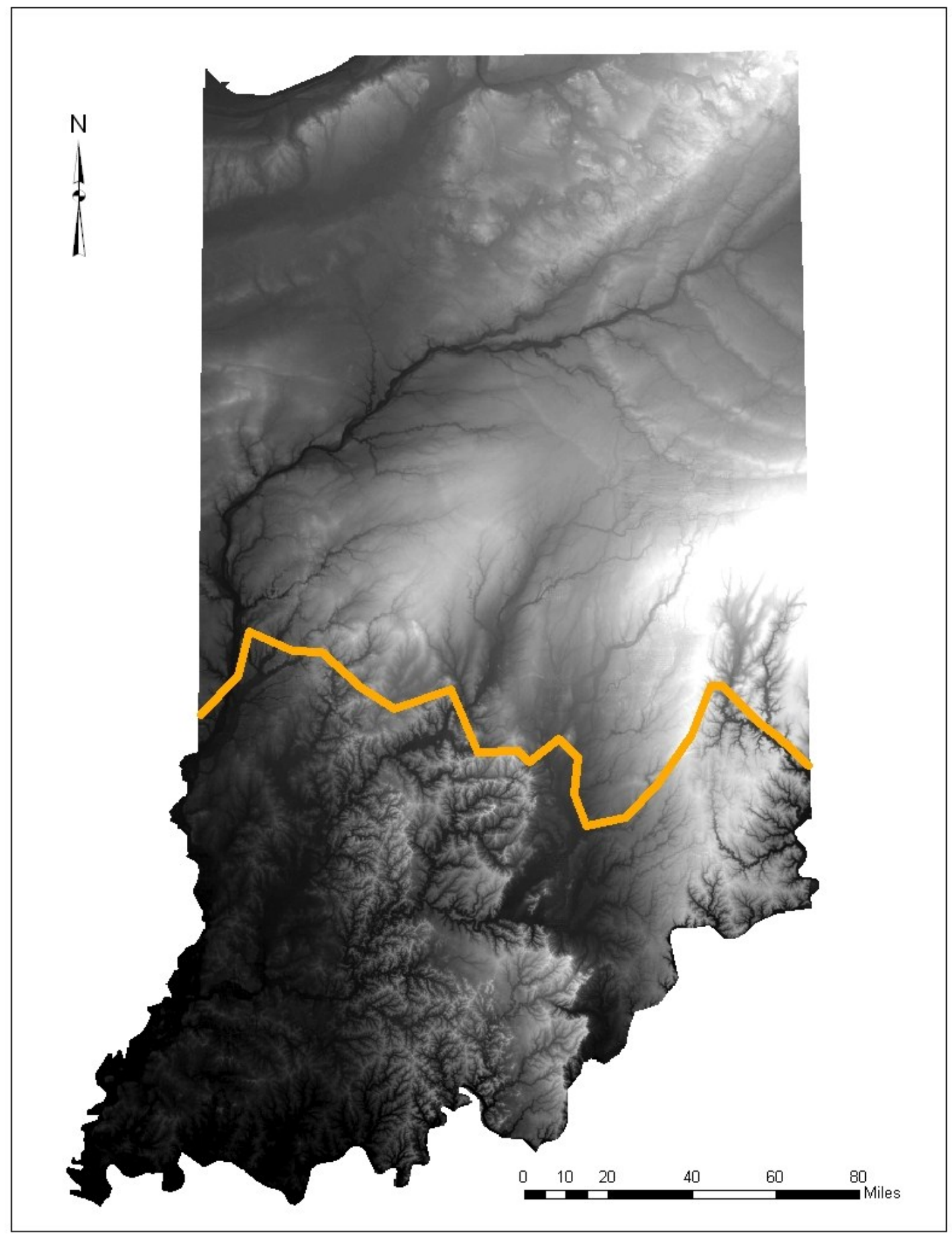

Figure 2.2. Southern border of Wisconsinan Glaciation 


\subsection{Data}

The study areas for this research were selected from the available USGS stream gages in Indiana. Figure 2.1 shows the location of the watersheds selected for this study. The original selection criteria used included: the smallest rural watersheds $(<30$ $\mathrm{mi}^{2}$ ) that have available 15-minute stream flow data from at least 1995 - 2003 or more recent if available. The 2001 National Land Cover Dataset (NLCD) was used to visually inspect whether watersheds were rural. Because of the limitations of available data for gauges in northern and central Indiana the criteria was relaxed to include watersheds less than $40 \mathrm{mi}^{2}$. Also four of the thirty selected watersheds contain significant urban area. These watersheds fell outside the original criteria but were retained to maintain better coverage across the state. Watershed selection was also done in consultation with a past study in Indiana by Rao (2004) and Knipe (2005) which divided the state into six hydrologically similar regions. These six regions are included in Figure 2.1. Table 2.1 lists the watersheds selected for this study. The 15minute stream flow data is available at the USGS Instantaneous Data Archive website (http://ida.water.usgs.gov/ida/). 
Table 2.1. USGS stream gauges selected

\begin{tabular}{lccc}
\hline Station Name & $\begin{array}{c}\text { Station } \\
\text { Number }\end{array}$ & Region & $\begin{array}{c}\text { Area } \\
\left(\mathrm{mi}^{2}\right)\end{array}$ \\
\hline WEESAU CREEK NEAR DEEDSVILLE, IN & 3328430 & North & 8.9 \\
GALENA RIVER NEAR LAPORTE, IN & 4096100 & North & 14.9 \\
FORKER CREEK NEAR BURR OAK, IN & 4100252 & North & 19.2 \\
RIMMELL BRANCH NEAR ALBION, IN & 4100295 & North & 10.7 \\
SOLOMON CREEK NEAR SYRACUSE, IN & 4100377 & North & 32.5 \\
FISH CREEK AT HAMILTON, IN & 4177720 & North & 37.5 \\
SPY RUN CREEK AT FORT WAYNE, IN & 4182810 & North & 14.0 \\
COBB DITCH NEAR KOUTS, IN & 5517890 & North & 30.3 \\
IROQUOIS RIVER AT ROSEBUD, IN & 5521000 & North & 35.6 \\
JUDAY CREEK NEAR SOUTH BEND, IN & 4101370 & North & 38.0 \\
& & & \\
WHITEWATER RIVER NEAR ECONOMY, IN & 3274650 & Central & 10.4 \\
LITTLE MISSISSINEWA RIVER AT UNION CITY, IN & 3325311 & Central & 9.7 \\
BIG LICK CREEK NEAR HARTFORD CITY, IN & 3326070 & Central & 29.2 \\
KOKOMO CREEK NEAR KOKOMO, IN & 3333600 & Central & 24.7 \\
BUCK CREEK NEAR MUNCIE, IN & 3347500 & Central & 35.5 \\
CROOKED CREEK AT INDIANAPOLIS, IN & 3351310 & Central & 17.9 \\
PLEASANT RUN AT ARLINGTON AV, & 3353120 & Central & 7.6 \\
INDIANAPOLIS, IN & 3353637 & Central & 17.0 \\
LITTLE BUCK CREEK NEAR INDIANAPOLIS, IN & 3353700 & Central & 28.8 \\
WEST FORK WHITE LICK CREEK AT DANVILLE, IN & 3357350 & Central & 3.0 \\
PLUM CREEK NEAR BAINBRIDGE, IN & 3302300 & South & 16.1 \\
LITTLE INDIAN CREEK NEAR GALENA, IN & 3302680 & South & 19.0 \\
WEST FORK BLUE RIVER AT SALEM, IN & 3303400 & South & 7.9 \\
CROOKED CREEK NEAR SANTA CLAUS, IN & 3342100 & South & 16.7 \\
BUSSERON CREEK NEAR HYMERA, IN & 3366200 & South & 9.3 \\
HARBERTS CREEK NEAR MADISON, IN & 3368000 & South & 11.4 \\
BRUSH CREEK NEAR NEBRASKA, IN & 3371520 & South & 24.1 \\
BACK CREEK AT LEESVILLE, IN & 3372300 & South & 10.9 \\
STEPHENS CREEK NEAR BLOOMINGTON, IN & 3374455 & South & 12.8 \\
PATOKA RIVER NEAR HARDINSBURG, IN & 3375800 & South & 21.8 \\
HALL CREEK NEAR ST. ANTHONY, IN & & & \\
\hline
\end{tabular}




\section{CHAPTER 3. METHODOLOGY}

\subsection{Methodology Overview}

The Clark SUH Method was selected for this study to gain some insight into how watershed storage affects runoff hydrographs. Equations for estimating the time of concentration $\left(\mathrm{t}_{\mathrm{c}}\right)$ and storage coefficient $(\mathrm{R})$ of the Clark unit-hydrograph method were

developed for small rural watersheds [3-38 square miles $\left.\left(\mathrm{mi}^{2}\right)\right]$ throughout Indiana. Equations were developed from rainfall-runoff data for 90 events across 30 watersheds. Data for 7 watersheds were used to verify the equations. $R$ and $t_{c}$ were determined by optimizing the rainfall-runoff data using the U.S. Army Corps of Engineers HEC-HMS software. The HEC-HMS model structure was developed using the GIS application HEC-GeoHMS. Regression relationships between watershed geomorphology, and $t_{c}$ and $\mathrm{R}$ were determined using multiple linear regression. Equations were developed for each region separately and for the entire state.

\subsection{GIS Analysis}

The important computer programs used in extracting the geomorphologic parameters of the watersheds included ArcHydro and ArcGIS 9.2. The National Elevation Dataset (NED) digital elevation models (DEMs) were downloaded from USGS. For this study $30 \mathrm{~m}$ resolution DEMs were used. The USGS National 
Hydrography Dataset (NHD)stream network file clipped for Indiana was also used as an input for ArcHydro. From the DEM and NHD stream network, necessary raster files such as the flow accumulation grid and flow direction grid were created. Using ArcHydro with the DEM and stream network, the boundaries of the study watersheds were extracted. These watershed polygons were saved in geodatabases which calculated the area and perimeter.

From the ArcHydro output files used to generate the watershed polygons, the geomorphologic parameters listed and defined in Tables 3.1 and 3.2 were computed. The first nine parameters, are leased relate area and length measurements while the last nine are calculated using relief and the stream network. An additional routine within ArcHydro was used to calculate basin length, and a new feature class was created to measure the maximum straight-line length of basin from mouth to divide for the basin shape factor $\left(\mathrm{S}_{\mathrm{b}}\right)$. Simple GIS techniques were used to extract other measurements. For example, a selection of the streams within the watershed polygon was performed to calculate the total stream length and number of streams within the watershed. This data was used to calculate the drainage density and stream frequency. The USGS Stream Stats web-based GIS interface was used to calculate additional geomorphologic characteristics: contributing drainage area (CDA), 10-85\% Slope (Slope), percent of area covered by water or wetland (Water), percent of area that is urban land cover (ULC), and main channel length (MCh). Stream Stats is a web-based GIS interface that provides users with analytical tools to calculate streamflow statistics and watershed characteristics from user selected stream locations. To represent the depression storage 
of each watershed, the raster calculator within ArcMap was utilized to calculate the difference in the filled DEM computed during terrain processing and the raw DEM. The resulting raster has two categories: one represents raster cells that were unchanged and the other category represents the raster cells that were filled because they were sinks. Sinks are raster cells that are surrounded by cells with higher elevation leaving no route for water to "flow". The raster cells that are sinks must be "filled" so ArcHydro can calculate the raster files mentioned at the beginning of this section. Besides the Stream Stats and depression storage parameters Table 3.2 also has three composite parameters. These are named HKR (Hickok et al., 1959), Gray (Gray 1961), and Murphey (Murphey et al., 1977). These parameters are explained by the following equations.

$$
\begin{aligned}
& H K R=\frac{A_{w}}{C_{s} \times \sqrt{D}} \\
& \text { Gray }=\frac{\mathrm{L}_{\mathrm{ca}}}{\sqrt{C_{s}}}
\end{aligned}
$$

Murphey $=\frac{S_{b}}{A_{w}}$

Refer to Table 3.1 for an explanation of the symbols used in these composite parameters. 


\section{Table 3.1 Definition of geomorphologic parameters}

Parameters, Symbol

Drainage area, $A_{w}$

Basin perimeter, $L_{p}$

Basin length $L_{b}$

$\mathrm{L}_{\mathrm{ca}}, L_{c a}$

Form factor, $R_{f f}$

Circulatory ratio, $R_{c}$

Elongation ratio, $R_{e}$

Basin shape factor, $\mathrm{S}_{\mathrm{b}}$

Unity shape factor, $\mathrm{R}_{\mathrm{u}}$

Basin relief, $H$

Relief ratio, $R_{h}$

Relative relief, $R_{p}$

Drainage density, $D$

Ruggedness number, $R_{n}$

Channel Maintenance, $C$

Fineness ratio, $R_{f}$

Stream frequency, $C_{f}$

Basin slope (\%), $L_{S}$

Main channel slope, $C_{s}$

\section{Definition}

The total area projected upon a horizontal plane contributing overland flow to the stream segment of the given order and all segments of lower order.

The length measured along the divide of the drainage basin as projected on to the horizontal plane of the map.

The longest dimension of a basin parallel to the principal drainage line.

The length from the basin outlet to a point adjacent to the centroid.

A dimensionless parameter defined as the ratio of basin area, $\mathrm{A}_{\mathrm{w}}$ to the square of basin length, $\mathrm{L}_{\mathrm{b}}^{2}$

A dimensionless parameter defined as the ratio of the basin area of a given order, $A_{w}$ to the area $A_{p}$ of a circle having a circumference equal to the basin perimeter, $\mathrm{L}_{\mathrm{p}}$.

The ratio of diameter of a circle, $\mathrm{D}_{\mathrm{c}}$ (with the same area as that of the basin) to length, $\mathrm{L}_{\mathrm{b}}$. $\left(\mathrm{D}_{\mathrm{c}} / \mathrm{L}_{\mathrm{b}}\right)$

The square of maximum straight-line length of basin (from mouth to divide) divided by total area.

The ratio of the basin length, $\mathrm{L}_{\mathrm{b}}$ to the square root of the basin area, $\mathrm{A}_{\mathrm{W}}$.

The maximum vertical distance between the lowest (outlet) and the highest (divide) points in the watershed.

A dimensionless quantity, defined as the ratio of maximum basin relief, $\mathrm{H}$ to horizontal distance along the longest dimension of the basin parallel to the principal drainage line, $\mathrm{L}_{\mathrm{b}}$.

The ratio of basin relief, $H$ to the length of the perimeter, $L_{p}$.

The ratio of the total length of all streams within a watershed to the watershed area, $\mathrm{A}_{\mathrm{w}}$.

Product of relief, $\mathrm{H}$ and drainage density, $\mathrm{D}$.

The ratio of the drainage area to the total length of all streams in the network.

The ratio of channel lengths to the length of basin perimeter.

The total number of streams within $A_{w}$.

Average grid slope computed by ArcGIS.

Slope of a line drawn along the measured profile of main channel. 


\section{Table 3.2. Definition of additional geomorphological parameters}

Parameters, Symbol

10-85\% Slope, Slope

$\%$ Water/Wetland, Water

\%UrbanLC, $U L C$

Contributing DA, $C D A$

Curve Number, $C N$

Main Channel Length, MCh

HKR, $H K R$

Gray, G

Murphey, $M$

\% Sinks, Sinks
Definition

Average of channel elevations at points 10 and 85 percent above gage

Percent of basin open water and herbaceous wetland from NLCD

Percentage of basin with urban development

Area that contributes flow to a point on a stream

Average curve number weighted by area

Length of longest flowline - head of stream to watershed outlet

$\mathrm{A}_{\mathrm{w}} /\left(\mathrm{C}_{\mathrm{s}} * \sqrt{\mathrm{D}}\right)$

$\mathrm{L}_{\mathrm{ca}} / \sqrt{ } \mathrm{C}_{\mathrm{s}}$

$\mathrm{S}_{\mathrm{b}} / \mathrm{A}_{\mathrm{W}}$

Percentage of basin DEM (clipped by watershed polygon) filled 


\subsection{Rainfall-Runoff Event Selection}

Rainfall-runoff events for use in this study were selected to conform as close as possible to the assumptions of the UH theory. Namely, the unit volume of surface runoff is equal to excess precipitation resulting from a storm of uniform intensity over a given duration. It is recommended by Viessman et al. (1989) that storms utilized to determine unit hydrographs should include:

- $\quad$ a simple structure which results in a well defined hydrograph with a distinct peak

- $\quad$ uniform rainfall distribution for the duration of rainfall excess

- uniform spatial distribution (of rainfall) over the entire watershed

Viessman et al. (1989) also recommend that the direct-runoff of storms selected for analysis should range from 0.5 to 1.75 in. This is because design storms used for further analysis would typically fall within this range. Storm events selected for this study were selected based on these criteria:

- $\quad$ Available USGS streamflow data during 1995-2006.

- The hydrographs were isolated events with well defined single peaks between March and June.

In a few cases, storms from late February were considered because of the quality of the available data. The precipitation data was also scrutinized to ensure no data was flagged as snowfall. Also, events were selected so there was little to no rainfall-runoff events five days prior and following a selected event. The objective in this approach 
was to minimize the effect of antecedent conditions and find the best single peaked storms. These criteria for hydrograph selection would yield the highest seasonal streamflows, with the most consistent antecedent moisture conditions, and rainfall events that covered the largest area. Precipitation data was obtained from the National Climactic Data Center (NCDC) for precipitation gauges across Indiana. Fifteen minute precipitation data was selected from the nearest precipitation gauge corresponding to the date and time of the selected streamflow hydrographs. A total of 90 rainfall-runoff events were selected, three per watershed, for calibration.

\subsection{Hydrologic Modeling}

Hydrologic modeling was performed with the U.S. Army Corp. of Engineer's (USACE) Hydrologic Engineering Center - Hydrologic Modeling Software (HECHMS). The Geospatial Hydrologic Modeling Extension (HEC-GeoHMS), a software package for use with Environmental Systems Research Institute's (ESRI) ArcMap, was used to create the hydrologic schematic of the watershed and stream network. Dividing the watersheds into subbasins was an important step in modeling. Utilizing HECGeoHMS, a stream threshold of $10 \%$ of the entire drainage area was selected. Thus, when an area equivalent to $10 \%$ of the watershed area drains to a point, a stream line is initiated and proceeds to the outlet. The threshold of $10 \%$ was chosen to keep the amount of subbasins per watershed at a manageable number. This resulted in approximately 3-10 subbasins per watershed. HEC-GeoHMS results were then imported to HEC-HMS for simulation and optimization. A more thorough explanation 
of HEC-GeoHMS can be found in the technical documentations available at the USACE’s Hydrologic Engineering Center website (http://www.hec.usace.army.mil/).

HEC-HMS requires the selection of specific processes for losses, hydrograph transform method, baseflow type, and routing. These processes are used in the hydrologic computations. The initial and constant-loss rate method was used for optimization to match effective precipitation depth to the direct-runoff depth of the observed streamflow hydrograph. Values for initial-loss and constant-loss rate were determined during HEC-HMS optimization to match effective precipitation depth to the direct runoff depth of the selected hydrographs. These values were not considered further in the analysis. Baseflow separation was performed manually before observed hydrographs were used in modeling. For the majority of storms the baseflow was estimated by extending the trend in flow throughout the entire hydrograph prior to the start of the storm. This was deemed acceptable because the events chosen were isolated and the flow returned to pre-event conditions relatively quickly. For storms that had a long recession limb before hydrographs returned to pre-event flows the straight line method was used as described by Chow et. al. (1988). Routing was modeled as a pure lag (Equation 4).

$\mathrm{t}_{\text {lag }}=\frac{\mathrm{L}}{(\mathrm{V} * 60)}$

Where $t_{\text {lag }}$ is lag time in minutes, $L$ is reach length in feet, and $V$ is streamflow velocity in feet per second. This was deemed sufficient method because it minimized additional 
parameters for calibration and the attenuation of the hydrograph would be incorporated in the transform method chosen.

The Clark SUH method was chosen as the transform method because of its ability to incorporate the processes of translation and attenuation. Clark (1945) studied the translation of flow through a watershed and noted the time-area curve described this phenomena well. The time-area curve was defined as the fraction of watershed area contributing runoff to the outlet as a function of time since the start of effective precipitation (Straub et al. 2000). Translation is determined by using the time-area relationship described in Equation 5 (USACE, 2000).

$$
\frac{A_{t}}{A}=\left\{\begin{array}{c}
1.414\left(\frac{t}{t_{c}}\right)^{1.5} \text { for } t \leq \frac{t_{c}}{2} \\
1.414\left(1-\frac{t}{t_{c}}\right)^{1.5} \text { for } t \geq \frac{t_{c}}{2}
\end{array}\right\}
$$

Where $A_{t}$ is the cumulative watershed area contributing runoff at time $t, A$ is total watershed area, and $t_{c}$ is time of concentration. The Clark time of concentration $\left(t_{c}\right)$ bounds the time-area curve. Attenuation is modeled with the use of a storage coefficient $(\mathrm{R})$ that can be represented by a simple linear reservoir as:

$S=O R$

where $\mathrm{S}$ is watershed storage, $\mathrm{R}$ is the watershed storage coefficient (in hours), and $\mathrm{O}$ is the outflow from the watershed. It was assumed that the storage coefficient would represent the storage effects in the watersheds of Indiana. The USACE noted the use of the ratio $\mathrm{R} /\left(\mathrm{t}_{\mathrm{c}}+\mathrm{R}\right)$ tends to remain constant for a region (USACE, 1990). Values for 
the ratio $\mathrm{R} /\left(\mathrm{t}_{\mathrm{c}}+\mathrm{R}\right)$ were set as $0.5-0.7$ for north and central regions and $0.2-0.4$ for the south. These values were comparable to those used in (Straub et al. 2000). The $t_{c}$ for each subbasin was calculated using the NRCS Curve Number method for use as an initial value in optimization. Values of the Clark $t_{c}$ were estimated and used as an initial value during optimization. Initial values for $\mathrm{R}$ were back calculated from the ratio, $\mathrm{R} /\left(\mathrm{t}_{\mathrm{c}}+\mathrm{R}\right)$, defined previously. These initial values were only used as a starting point for the optimization process.

\subsection{Parameter Optimization}

Synthetic unit hydrographs were generated for 3 rainfall-runoff events per watershed. The SUH parameters $t_{c}$ and $\mathrm{R}$ were optimized by matching the estimated SUH to the observed streamflow for each event. The priority of the optimization was to match the peak flow rate $\left(\mathrm{Q}_{\mathrm{p}}\right)$, time to peak $\left(\mathrm{t}_{\mathrm{p}}\right)$, and the overall hydrograph shape. The criteria for successful optimization were: an estimated $Q_{p}$ within 5\% of observed values, $t_{p}$ within 15 minutes of observed and similar overall hydrograph shape through graphical comparison. Of the 90 optimization trials 75 events satisfied the optimization criteria, 6 events had peak flows within 5-10\% of observed and 9 events did not meet either criteria. An investigation into the unsuccessful optimizations showed Juday Creek watershed failed to produce a successful optimization. This study area was dropped from the analysis. The optimization procedure required optimization run configurations be constructed for each event. Optimization was performed using the following procedure. 
1. Run configurations were created defining the basin model, meteorological model, and control specifications

2. Parameters to be optimized were selected. The Clark $t_{c}$ and $R$ in hours, initial losses in inches, and constant loss rate in inches per hour were used.

3. Initial values for all parameters were estimated and input.

Optimization was performed using a trial and error approach. Parameters outlined above were adjusted to closely match the Clark SUH to the observed hydrograph. There are six objectives functions used for optimization methods available in HEC-HMS: Peak-Weighted RMS, Percent Error Peak, Percent Error Volume, Sum of Absolute Residual, Sum of Squared Residual, Time-Weighted Error. Initially the Peak-Weighted RMS method was used, but if that did not yield good results other methods were utilized to obtain the best results.

Once optimization was complete, several checks were made to ensure the quality of the optimizations. Values of excess precipitation were compared to the resulting direct runoff calculated during optimization to ensure the values were equal. Peak flow rates and time to peak were compared to the observed to ensure values optimized sufficiently followed the observed hydrographs. Optimized Clark $t_{c}$ and $R$ were compared and averaged for all events per watershed to ensure hydrographs produced were consistent. 
HEC-HMS does not calculate traditional UHs directly so an additional run configuration was created for each basin model to calculate the 5-minute UH for each watershed.

1. Average values of $t_{c}$ and $R$ (from the optimizations) were used in this scenario. Representative values from the optimization were used for lag times.

2. Losses were set to zero because a UH is a direct runoff hydrograph.

3. A new meteorological model was created with a one inch pulse of rainfall of 5 minute duration. This is the definition of a 5-minute $\mathrm{UH}$.

4. The results of the calculated UHs were checked to ensure a volume of 1 inch and $\mathrm{Q}_{\mathrm{p}}$ and $\mathrm{t}_{\mathrm{p}}$ were recorded for each.

The values of $\mathrm{Q}_{\mathrm{p}}$ and $\mathrm{t}_{\mathrm{p}}$ provided a basis on which to compare hydrographs of watersheds across the three regions of Indiana. These two points on the hydrograph along with the recession times would give some insight in to the shape of $\mathrm{UH}$ hydrographs for watersheds across the state as well. 


\section{CHAPTER 4. STATISTICAL ANALYSIS}

After optimization and 5-minute UH calculations were complete, statistical analysis was performed to establish a statistically significant relationship between the geomorphology and UH shape of watershed across Indiana. This was done to assist in the selection of ideal geomorphologic parameters that might best describe the Clark SUH characteristics across the state. Three tests to determine a significant difference in the mean (between each region) were performed on all geomorphologic and hydrograph parameters. This included: Student t-test, Tukey-Kramer, and the Wilcoxon Rank Sum. Both the Student t-test and Tukey-Kramer assume a normal distribution and equal variances. In the event variables violated these assumptions, the Wilcoxon Rank Sum was included because it is nonparametric.

\subsection{Student t-Test}

The Student t-Test was employed to determine whether there was a statistical significance in the difference in the mean of each parameter across the three regions. The mean of each parameter measured for all 30 watersheds of each region (ten per region) were calculated. This resulted in three mean values that were compared for each parameter. A pairwise comparison of each mean was performed so each region was tested for a 
significant difference from the other two. Calculation of the test statistic required the use of a pooled variance:

$s_{p}^{2}=\frac{\left(n_{1}-1\right) s_{1}^{2}+\left(n_{2}-1\right) s_{2}^{2}}{\left(n_{1}-1\right)+\left(n_{2}-1\right)}$

To test the hypothesis:

$$
\begin{gathered}
\mathrm{H}_{\mathrm{o}}: \mu_{1}-\mu_{2}=0 \quad \mathrm{H}_{\mathrm{a}}: \mu_{1}-\mu_{2} \neq 0 \\
\mathrm{t}^{*}=\frac{\left(\overline{\mathrm{Y}}_{1}-\overline{\mathrm{Y}}_{2}\right)-0}{\mathrm{~s}_{\mathrm{p}} \sqrt{\frac{1}{\mathrm{n}_{1}}+\frac{1}{\mathrm{n}_{2}}}} \\
\text { Reject } \mathrm{H}_{\mathrm{o}} \text { when } t^{*}>t_{1-\frac{\alpha}{2}}, v \text { where } v=n_{1}+n_{2}-2
\end{gathered}
$$

By rejecting the null hypothesis at a significance level of $\alpha=0.05$ we can show the means are significantly different.

\subsection{Tukey-Kramer Pairwise Test}

The Tukey-Kramer pairwise comparison also tests the same hypothesis as the Student t-Test:

$$
\mathrm{H}_{\mathrm{o}}: \mu_{1}-\mu_{2}=0 \quad \mathrm{H}_{\mathrm{a}}: \mu_{1}-\mu_{2} \neq 0
$$

The Tukey-Kramer procedure uses the studentized range distribution. Studentized means were adjusted by dividing by an estimate of the population standard deviation. Consider $\mathrm{r}$ independent observations $\mathrm{Y}_{1}, \ldots, \mathrm{Y}_{\mathrm{r}}$ from a normal distribution with mean $\mu$ and variance $\sigma^{2}$. Let $w$ be the range for the observations, or the maximum observation 
minus the minimum observation, and assume an estimate of the variance $\mathrm{s}^{2}$ based on $v$ degrees of freedom and independent of the observations. The ratio of $w / \mathrm{s}$ becomes the studentized range denoted by (Kutner et al 2005):

$q(r, v)=\frac{w}{s}$

The distribution of $q$ depends on $\mathrm{r}$ and $v$, and is typically tabulated for selected percentiles in many statistical textbooks (Kutner et al 2005). The Tukey test statistic is calculated as:

$q^{*}=\frac{\sqrt{2} \widehat{D}}{s\{\widehat{D}\}}$

where $\widehat{D}$ and $\mathrm{s}^{2} \widehat{D}$ are based on family confidence intervals and discussed in further detail by Kutner et al. (2005). $\quad \mathrm{H}_{\mathrm{o}}$ is concluded if $\left|q^{*}\right| \leq q\left(1-\alpha ; r ; n_{T}-r\right)$ : otherwise, $\mathrm{H}_{\mathrm{a}}$ is concluded. In this study comparisons were performed at a significance level of $\alpha=0.05$.

\subsection{Wilcoxon Rank Sum Test}

The Wilcoxon Rank Sum Test is useful for comparison when data sets do not exhibit a normal distribution that is necessary for the Student t-Test. This rank sums method was presented in a paper by Wilcoxon (1945). The method combines the samples of two tests as $\mathrm{n}_{1}+\mathrm{n}_{2}$ and ranks the sorted values. A value of $W$ is given to sum of the ranks for each sample. Depending on the size of the data set the standard distribution used for this test varies. The statistical software JMP 6.0 was utilized to calculate the test statistic and perform the analysis. 


\section{CHAPTER 5. DEVELOPMENT OF REGIONAL REGRESSION EQUATIONS}

Multiple regression analysis is a useful method in developing regional parameter estimation equations (Abdulla and Lettenmaier, 1997). Regional regression equations are useful for estimating parameters at ungauged sites, and relatively straight forward for using information from gauged sites for equation development. The typical multiple regression model is of the form:

$Y=B_{1} X_{1}+B_{2} X_{2} \ldots+B_{n} X_{n}$

where $Y$ is the dependent variable (in this case Clark SUH parameters), $X_{1}, X_{2}, \ldots, X_{n}$ are independent variables (watershed characteristics) and $B_{1}, B_{2}, \ldots, B_{n}$ are unknown coefficients. The unknown coefficients are determined utilizing the method of least squares (Abdulla and Lettenmaier, 1997). Stepwise selection techniques were employed to select the best number of independent variables for the regression model and specific variables that would be most useful for estimation of the Clark SUH parameters.

Several regression models were developed and investigated. SAS statistical software package was used to run stepwise regression procedures for the selection of best multiple linear regression models. The goal of stepwise regression is to take a set 
of independent variables and add them to the model one at a time in a certain manner until all variables have entered the model or a specific criteria has been met (Cody and Smith 2006). The criteria used in this study required all variables added to the regression were statistically significant to a level of $\alpha=0.05$. For stepwise selection, a variable is added if it meets the significance level; as variables are added, if the significance of a previously entered variable diminishes that variable is removed. In summary variables can be added and removed throughout the process until the procedure has attempted to add all variables. It must also be noted that stepwise regression does not always select the best model, but usually an acceptable one (Draper and Smith 1981). An alternative procedure was used to select the best subsets of models with the highest $r$-squared values for regression equations with one, two, and eventually all variables used in the regression. This procedure did not consider the significance of each variable, but helped gain some insight into what variables consistently were used in the best regression models.

Two scenarios were used to develop five regression models for each Clark SUH parameter. Scenario 1 used all 29 watershed characteristics as possible independent variables. Scenario 2 used only the 10 geomorphologic parameters measured using the USGS Stream Stats application. The goal of Scenario 2 was to find out if a simpler list of variables could perform as well as the large list which may have some significant multicollinearity effects, that is, some variables are correlated to each other and explain the same amount of variance. The five regression models investigated were: 


\section{Linear Model}

$Y=B_{O}+B_{1} X_{1}+B_{2} X_{2} \ldots+B_{n} X_{n}$

2. Logarithmic Model 1

$$
\log (Y)=B_{O}+B_{1} \log \left(X_{1}\right)+B_{2} \log \left(X_{2}\right) \ldots+B_{n} \log \left(X_{n}\right)
$$

3. Logarithmic Model 2 (only independent variables transformed)

$$
Y=B_{O}+B_{1} \log \left(X_{1}\right)+B_{2} \log \left(X_{2}\right) \ldots+B_{n} \log \left(X_{n}\right)
$$

4. Square Root Model 1

$$
\sqrt{Y}=B_{O}+B_{1} \sqrt{ } X_{1}+B_{2} \sqrt{ } X_{2} \cdots+B_{n} \sqrt{X_{\mathrm{n}}}
$$

5. Square Root Model 2 (only independent variables transformed)

$$
Y=B_{O}+B_{1} \sqrt{ } X_{1}+B_{2} \sqrt{ } X_{2} \ldots+B_{n} \sqrt{ } \mathrm{X}_{\mathrm{n}}
$$

Before models were selected to progress to the validation step, several diagnostics were performed to test whether the regression models obeyed the general assumptions of multiple linear regression. The four assumptions addressed whether: variables are normally distributed, overall model fit (linear relationship exists), independent variables are measured without error, and variance is equal across all independent variables. Once a model was selected ANOVA tables and necessary plots were developed using Excel. Normal probability plots were used to examine normality of the variables. Ftest values were used to test overall significance of the entire regression model. The linear relationship of independent variables to dependent variables was tested using 
residual plots against predicted values. Variables were assumed to be error free because of the computational accuracy of using remote sensing and GIS datasets. Finally, equal variance across all independent variables was tested by plotting the standardized residuals of each and confirming they were randomly distributed about the X-axis. Complete ANOVA tables and regression statistics are provided in Appendix A. 


\section{CHAPTER 6. RESULTS}

The statistical tests mentioned in the previous chapters were performed first on the geomorphological parameters. This was done to learn what geomorphology distinguished watersheds from region to region. The Clark SUH parameters, $t_{c}$ and $R$, were also analyzed using the same statistical tests. From the optimized models, 5minute UHs were calculated, as described in Section 3.5, for each watershed. The resulting $Q_{p}$ and $t_{p}$ were used for comparison. Finally, the best regression equations were used on 7 verification rainfall runoff events for watersheds selected from the study to represent the entire 30 watersheds best. The following sections discuss the results of the statistical analysis and regressions for each region in detail.

\subsection{Statistical Analysis}

The statistical test conducted on the geomorphologic parameters yielded results that support the geomorphology discussed in Chapter 2, namely southern Indiana is different from the north and central regions of the state. There was no significant difference between the north and central regions for any of the geomorphologic parameters dealing with slope. Significant differences in slope were observed between the southern region and each of the other two regions. 
central regions. The central slopes of the and northern region are not significantly different from each other (at $\alpha=0.05$ ). All parameters involving slope and relief show this relationship. The box plots showing mean values and the variation of the significantly different parameters are displayed in Figures 6.1-6.10. In other words, the central and northern region's watersheds have statistically similar slopes. The percent water/wetland parameter showed the northern region's watersheds to be statistically different from the other two regions. The northern region also showed a significantly higher percentage of sinks calculated from the DEM, which indicates more depression storage. Main channel lengths for the southern region are statistically shorter, and differ from the north and central regions. The central region was shown to be statistically different for percent of urban land cover, but this is due to the proximity of several watersheds to Indianapolis. Table 6.1 summarizes the results. Refer to Tables 3.1 and 3.2 for a description of the geomorphologic parameters.

Table 6.1. Results of statistical analysis of geomorphologic parameters

\begin{tabular}{|c|c|c|c|}
\hline Parameter & & & \\
\hline & Related to Slope & Region of Difference & How Region Differs \\
\hline 10-85 Slope & $\mathrm{X}$ & South & \multirow[t]{7}{*}{ Statistically higher slopes } \\
\hline HKR & $X$ & South & \\
\hline Cs & $\mathrm{X}$ & South & \\
\hline Ls & $\mathrm{X}$ & South & \\
\hline $\mathrm{Rn}$ & $\mathrm{X}$ & South & \\
\hline $\mathrm{Rp}$ & $\mathrm{X}$ & South & \\
\hline $\mathrm{Rh}$ & $\mathrm{X}$ & South & \\
\hline Water & & North & $\begin{array}{l}\text { Statistically higher \% of } \\
\text { Water/Wetlands }\end{array}$ \\
\hline$\%$ ULC & & Central & Statistically higher $\%$ of ULC \\
\hline $\begin{array}{l}\text { Main } \\
\text { Channel }\end{array}$ & & South & $\begin{array}{l}\text { Statistically shorter main } \\
\text { channel length }\end{array}$ \\
\hline Sinks & & North & Statistically higher $\%$ of Sinks \\
\hline
\end{tabular}



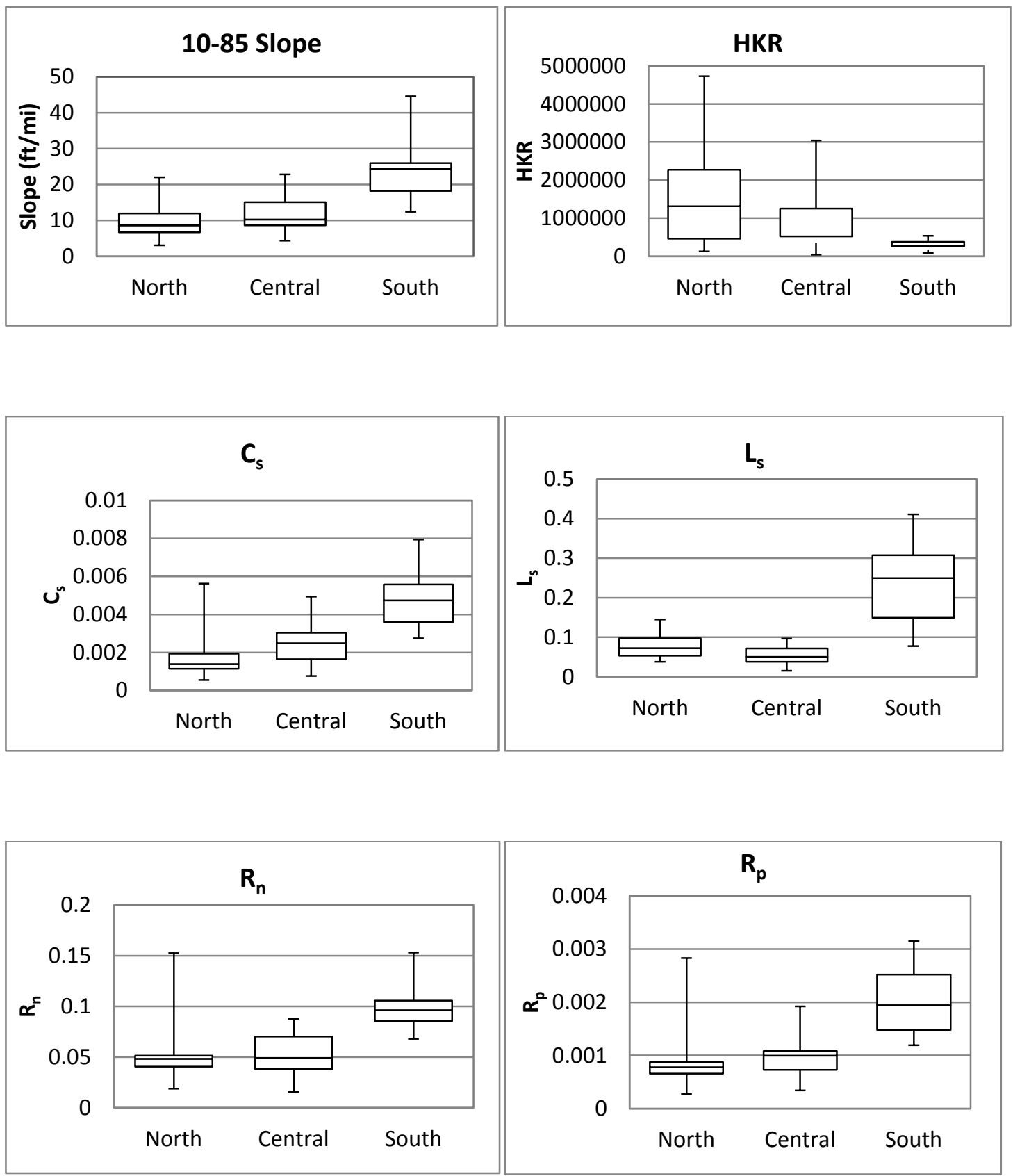

Figures 6.1-6.6. Box Plots displaying slope related geomorphologic parameters 

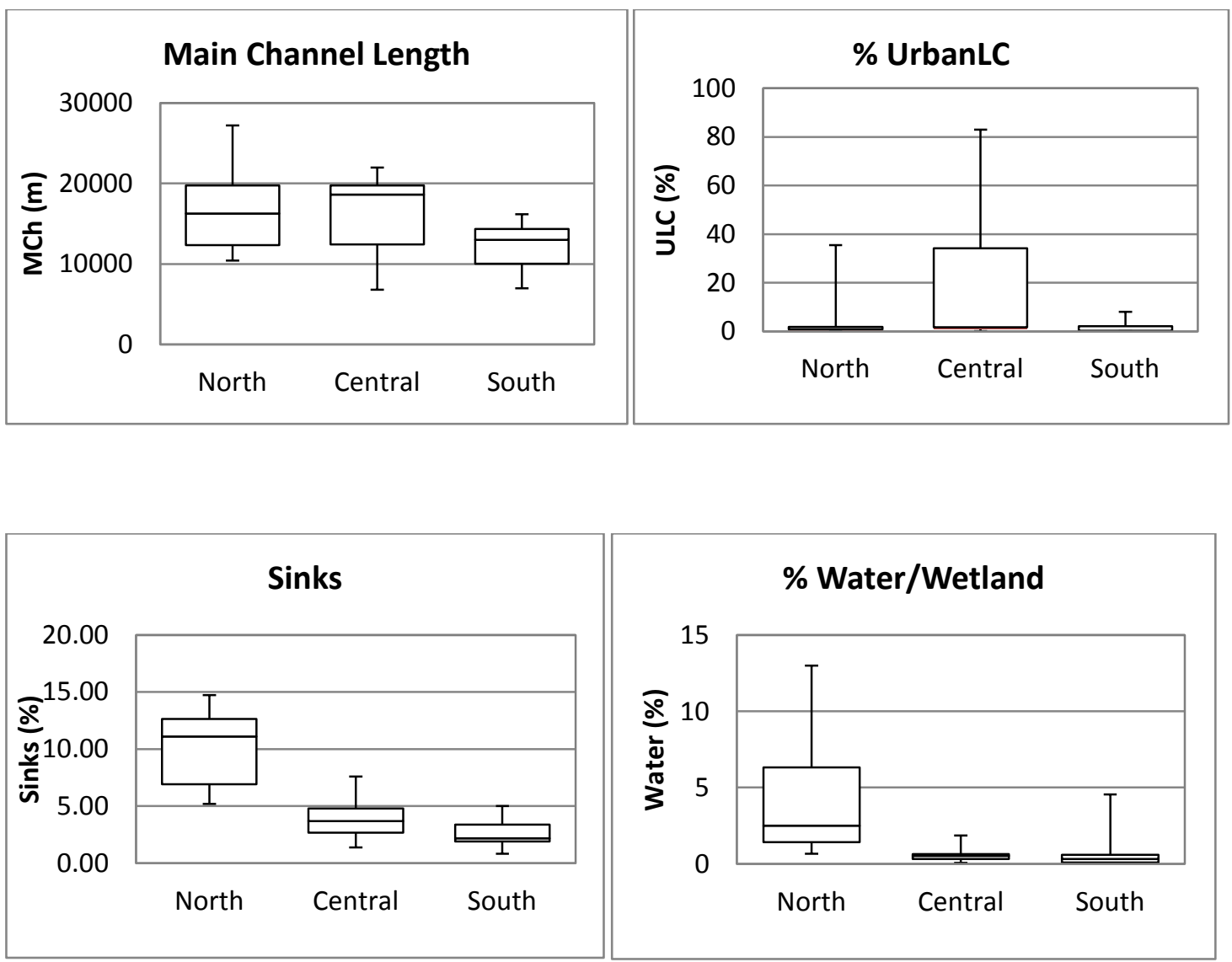

Figures 6.7-6.10. Box plots displaying other significant geomorphologic parameters

In summary the watersheds of northern and central Indiana are have significantly lower slopes than the southern watersheds. However, Northern Indiana tends to have a higher percentage of water/wetland features and depression storage. Central Indiana watersheds for this study will have some effects from the urbanized land cover of Indianapolis, but because of data constraints they were kept in the study. The central region shares the lower slopes seen in the north, but has lower depression storage characteristics. Southern Indiana watersheds were shown to have higher slopes and shorter main channel lengths and the least amount of depression storage. 


\subsection{Clark SUH Parameter Analysis}

Optimized values for $t_{c}$ and $R$ were obtained for each subbasin within each watershed. During optimization it was noted that $\mathrm{R}$ affected the peak flow values most, making the flows lower for higher values of $\mathrm{R}$. The $t_{c}$, as one would expect, had most control on the timing of the peak. Statistical analysis showed $\mathrm{R}$ values increased moving north in the state, but each region was found to significantly different from the other. The southern region showed statistically smaller $t_{c}$. This would support the analysis of the geomorphological parameters where it was found that the main channel lengths were shorter and steeper resulting in higher velocities and faster travel times through the southern watersheds. Values of the Clark SUH parameters for each watershed are provided in Figure 6.11 and Table 6.2.
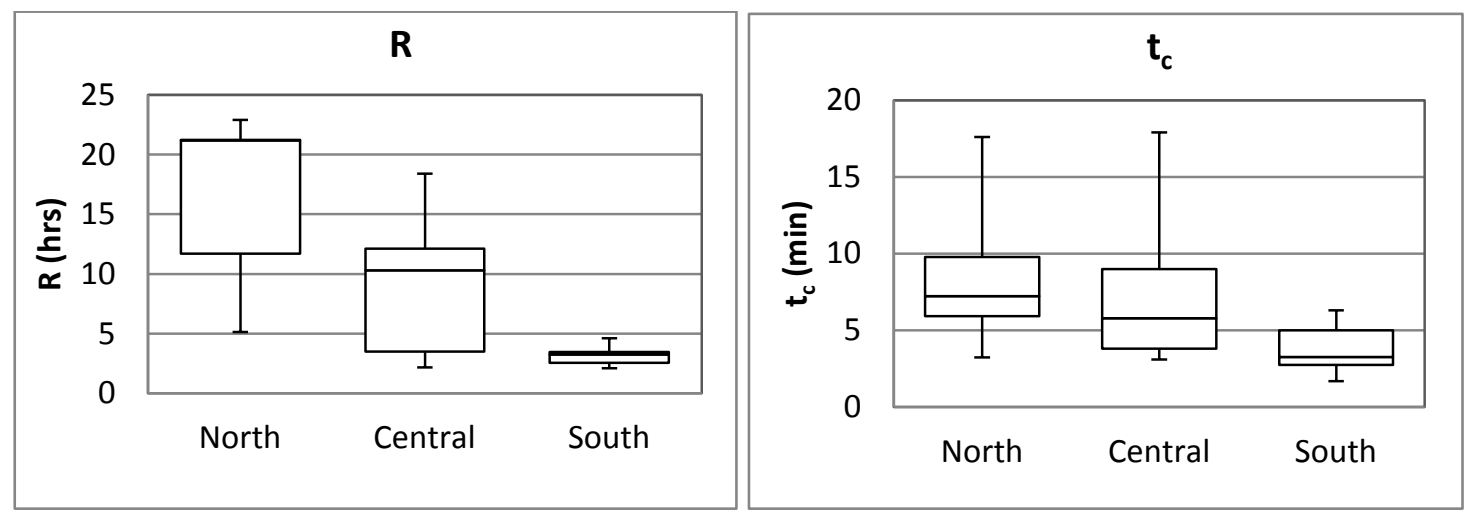

Figure 6.11. Box plot of optimized $R$ and $t_{c}$ values 
Table 6.2. Summary of Optimized Clark SUH parameters

\begin{tabular}{|c|c|c|c|c|c|}
\hline Name & Region & $\begin{array}{c}\text { Station } \\
\text { No. }\end{array}$ & $\begin{array}{c}\mathbf{A}_{\mathrm{w}} \\
\left(\mathrm{mi}^{2}\right)\end{array}$ & $\begin{array}{c}\mathbf{t}_{\mathrm{c}} \\
(\mathrm{hrs})\end{array}$ & $\begin{array}{c}R \\
\text { (hrs) }\end{array}$ \\
\hline WEESAU CREEK & $\mathrm{N}$ & 03328430 & 8.87 & 3.22 & 21.2 \\
\hline GALENA RIVER & $\mathrm{N}$ & 04096100 & 14.9 & 7.21 & 10.08 \\
\hline FORKER CREEK & $\mathrm{N}$ & 04100252 & 19.2 & 9.77 & 21.23 \\
\hline RIMMELL BRANCH & $\mathrm{N}$ & 04100295 & 10.7 & 5.91 & 11.69 \\
\hline SOLOMON CREEK & $\mathrm{N}$ & 04100377 & 32.5 & 13.17 & 22.9 \\
\hline FISH CREEK & $\mathrm{N}$ & 04177720 & 37.5 & 7.14 & 21.18 \\
\hline SPY RUN CREEK & $\mathrm{N}$ & 04182810 & 14 & 4.4 & 5.12 \\
\hline COBB DITCH & $\mathrm{N}$ & 05517890 & 30.3 & 7.99 & 19.69 \\
\hline IROQUOIS RIVER & $\mathrm{N}$ & 05521000 & 35.6 & 8.2 & 16.75 \\
\hline JUDAY CREEK & $\mathrm{N}$ & 04101370 & 38 & 10.01 & 19.73 \\
\hline Name & Region & $\begin{array}{c}\text { Station } \\
\text { No. }\end{array}$ & $\begin{array}{c}\mathbf{A}_{w} \\
\left(\mathrm{mi}^{2}\right)\end{array}$ & $\begin{array}{c}\mathbf{t}_{\mathrm{c}} \\
(\mathrm{hrs})\end{array}$ & $\begin{array}{c}\mathbf{R} \\
(\mathbf{h r s})\end{array}$ \\
\hline WHITEWATER RIVER & $\mathrm{C}$ & 03274650 & 10.4 & 3.33 & 3.22 \\
\hline $\begin{array}{l}\text { LITTLE MISSISSINEWA } \\
\text { RIVER }\end{array}$ & $\mathrm{C}$ & 03325311 & 9.67 & 17.9 & 16.73 \\
\hline BIG LICK CREEK & $\mathrm{C}$ & 03326070 & 29.2 & 5.76 & 12.47 \\
\hline KOKOMO CREEK & $\mathrm{C}$ & 03333600 & 24.7 & 10.02 & 18.4 \\
\hline BUCK CREEK & $\mathrm{C}$ & 03347500 & 35.5 & 5.81 & 11.05 \\
\hline CROOKED CREEK & $\mathrm{C}$ & 03351310 & 17.9 & 5.9 & 3.73 \\
\hline PLEASANT RUN & $\mathrm{C}$ & 03353120 & 7.58 & 3.56 & 2.15 \\
\hline LITTLE BUCK CREEK & $\mathrm{C}$ & 03353637 & 17 & 4.56 & 9.68 \\
\hline $\begin{array}{l}\text { WEST FORK WHITE } \\
\text { LICK CREEK }\end{array}$ & $\mathrm{C}$ & 03353700 & 28.8 & 12.02 & 10.9 \\
\hline PLUM CREEK & $\mathrm{C}$ & 03357350 & 3 & 3.08 & 3.41 \\
\hline Name & Region & $\begin{array}{c}\text { Station } \\
\text { No. }\end{array}$ & $\begin{array}{c}\mathbf{A}_{\mathrm{w}} \\
\left(\mathrm{mi}^{2}\right)\end{array}$ & $\begin{array}{c}t_{\mathrm{c}} \\
(\mathrm{hrs})\end{array}$ & $\begin{array}{c}\mathbf{R} \\
(\mathbf{h r s})\end{array}$ \\
\hline LITTLE INDIAN CREEK & $\mathrm{S}$ & 03302300 & 16.1 & 5.18 & 2.62 \\
\hline $\begin{array}{l}\text { WEST FORK BLUE } \\
\text { RIVER }\end{array}$ & $\mathrm{S}$ & 03302680 & 19 & 6.31 & 2.43 \\
\hline CROOKED CREEK & $\mathrm{S}$ & 03303400 & 7.86 & 2.9 & 3.14 \\
\hline BUSSERON CREEK & $\mathrm{S}$ & 03342100 & 16.7 & 5.79 & 4.26 \\
\hline HARBERTS CREEK & $\mathrm{S}$ & 03366200 & 9.31 & 4.47 & 3.35 \\
\hline BRUSH CREEK & $\mathrm{S}$ & 03368000 & 11.4 & 2.65 & 3.32 \\
\hline BACK CREEK & $\mathrm{S}$ & 03371520 & 24.1 & 2.7 & 4.61 \\
\hline STEPHENS CREEK & $\mathrm{S}$ & 03372300 & 10.9 & 3.6 & 3.49 \\
\hline PATOKA RIVER & $\mathrm{S}$ & 03374455 & 12.8 & 1.69 & 2.09 \\
\hline HALL CREEK & $\mathrm{S}$ & 03375800 & 21.8 & 2.83 & 2.5 \\
\hline
\end{tabular}




\subsection{Five-minute UH Analysis}

The 5-minute UHs were calculated based on the optimized parameters previously computed using the method described in section 3.4. The 5-minute UH was selected as a metric to establish the difference in peak flows and travel times across the regions of Indiana. Because the individual storm events used for calibration were of varying duration and runoff volume, the 5-min UH analysis was adopted for a more direct comparison of hydrographs with equal storm duration and runoff volume. The results are consistent with the results of all previous analysis. The $\mathrm{Q}_{\mathrm{p}}$ for the north and central regions is statistically lower than in the southern region. The box plots in Figure 6.12 \& 6.13 show a trend of decreasing peak flows from the south to the north of the state. The $t_{p}$ values also reinforce the trend discussed. For southern Indiana, the average $t_{p}$ are statistically shorter (Figure 6.13). This analysis established the difference in hydrograph shape and thus hydrology across Indiana.
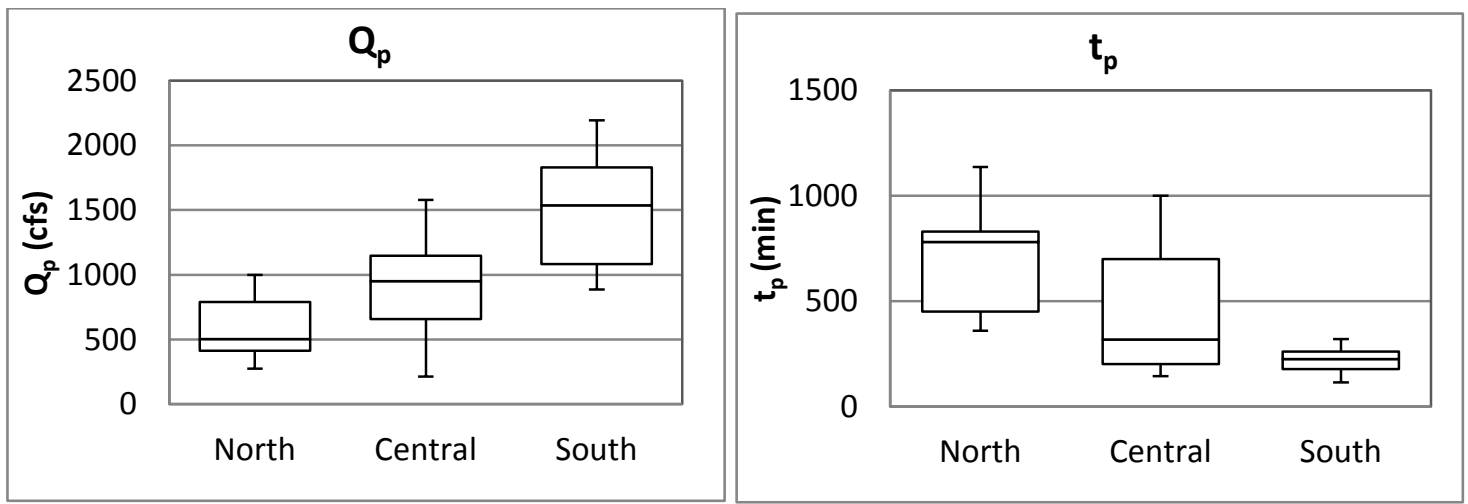

Figures 6.12-6.13. Box plots of 5-minute UH $Q_{p}$ and $t_{p}$ 


\subsection{Regression Models}

Each of the regression models developed for individual regions contained a unique set of variables. Of the five regression models, the Logarithmic Model 1 by far performed the best for Scenario 1 and 2 (Chapter 5) within in each region. A summary of the regression results are located in Appendix C. Regressions for each region had $\mathrm{R}^{2}$ values $>0.8$ with F-test model significance $<0.008$ for Log Model 1. The Log Model 1 regression for Scenario 1 (all geomorphological parameters considered for regression) performed best. Each regional equation contained a unique set of independent variables as well. The results from Scenario 2 (only Stream Stats parameters considered for regression) were not as good. The Logarithmic Model 1, again, performed best for Scenario 2, but $\mathrm{R}^{2}$ values were 0.47 and 0.63 for the north and central regions respectively. The logarithmic Scenario 2 regression for the southern region selected no significant independent variables at $\alpha=0.05$. One additional regression set for $\mathrm{t}_{\mathrm{c}}$ and $\mathrm{R}$ was considered for comparison with regional equations. These regression equations represent the entire state containing the most simple set of variables necessary to predict $t_{c}$ and $\mathrm{R}$. The rationale was to see if a simpler set of regression equations for the entire state could perform as well as the region specific regression equations. The following sections discuss the regression equations in detail for each region. The discussion will include the best Scenario 1 and Scenario 2 regression models for each Clark SUH parameter ( $\mathrm{R}$ and $\mathrm{t}_{\mathrm{c}}$ ). Refer to Appendix A for detailed regression statistics and ANOVA tables. 


\subsection{Regression Models - North Region}

The best regression model for predicting the Clark storage coefficients $(\mathrm{R})$ of Northern Indiana was represented by the Log Model 1 - Scenario 1. This regression model included urban land cover (ULC) and stream frequency $\left(\mathrm{C}_{\mathrm{f}}\right)$ as the significant variables. Both independent variables were significant at $\alpha=0.05$. The Linear Model - Scenario 2 regression also yielded a promising result. In Scenario 2 only the Stream Stats variables were used as possible independent variables. The 10-85\% slope (Slope) and percent of water/wetland features (Water) yielded a $R^{2}=0.88$. The $t_{c}$ was also best predicted by Log Model 1 - Scenario 1 and the second best model for $t_{c}$ was Log Model 1 - Scenario 2. In both equations for $t_{c}$ contributing drainage area (CDA) was the most significant independent variable. To summarize it seems $\mathrm{R}$ is best predicted with variables related to landuse/landcover, stream network, and slope. Time of concentration is more dependent on the size of the watershed. These equations are listed here in Table 6.2.

Table 6.3. Summary of best Northern Region regression equations.

\begin{tabular}{|c|c|c|c|}
\hline Regression Model & Transform & Scenario & $\mathbf{R}^{2}$ \\
\hline $\log (R)=1.139-0.164 \log (U L C)-0.819 \log \left(C_{f}\right)$ & $\begin{array}{c}\text { Log Model } \\
1\end{array}$ & 1 & 0.86 \\
\hline $\boldsymbol{R}=27-1.665($ Slope $)-1.506($ Water $)$ & $\begin{array}{l}\text { Linear } \\
\text { Model }\end{array}$ & 2 & 0.88 \\
\hline $\begin{array}{l}\log \left(t_{c}\right)= \\
-3.355+1.677 \log (C D A)+1.369 \log \left(C_{f}\right)+0.396 \\
\log (G)\end{array}$ & $\begin{array}{c}\text { Log Model } \\
1\end{array}$ & 1 & 0.97 \\
\hline $\log \left(\boldsymbol{t}_{c}\right)=-0.254+0.841 \log (\mathbf{C D A})-0.079 \log (\mathbf{U L C})$ & Log & 2 & 0.78 \\
\hline
\end{tabular}

All variables are log base 10-transformed except Linear Model.

Refer to Tables 3.1 and 3.2 for definitions of the independent variables 


\subsection{Regression Models - Central Region}

The central region has represented a transition region geomorphologically. In the previous chapter it was shown that the central region shares the lower slopes seen in the north, but has depression storage characteristics more in common with the southern region. Also, the presence of watersheds with more urban land cover adds a dimension of complexity. The best regression models for $t_{c}$ and $\mathrm{R}$ were again Log Model $1-$ Scenario 1. Fineness ratio $\left(\mathrm{R}_{\mathrm{f}}\right)$ and Slope provide the best prediction for R. Fineness ratio describes the relationship of channel lengths to basin perimeter. For the $t_{c}$ prediction, urban land cover (ULC) and slope variables $\left(\mathrm{L}_{\mathrm{s}}\right.$ and $\left.\mathrm{H}\right)$ performed best. Although both $\mathrm{L}_{\mathrm{s}}$ and $\mathrm{H}$ are slope-related, their correlation coefficients were low enough to remain in the regression model together. The Scenario 2 models both displayed much less success however their inclusion of similar independent variables illustrates that slope is an important factor in the central region.

Table 6.4. Summary of best Central Region regression equations.

\begin{tabular}{|c|c|c|c|}
\hline Regression Model & Transform & Scenario & $\mathbf{R}^{2}$ \\
\hline $\log (R)=1.727-2.722 \log \left(R_{f}\right)-0.932 \log ($ Slope $)$ & Log Model 1 & 1 & 0.86 \\
\hline$\sqrt{R}=6.189-0.949 \sqrt{ }($ Slope $)-0.048 \sqrt{ }($ ULC $)$ & Sqrt Model 1 & 2 & 0.82 \\
\hline $\begin{array}{l}\log \left(t_{c}\right)= \\
-1.944-0.927 \log \left(L_{s}\right)+0.956 \log (H)-0.125 \\
\log (U L C)\end{array}$ & Log Model 1 & 1 & 0.84 \\
\hline $\log \left(t_{c}\right)=1.574-0.769 \log ($ Slope $)$ & Log Model 1 & 2 & 0.41 \\
\hline
\end{tabular}

All variables are log base 10 transformed except Sqrt Model 1.

Refer to Tables 3.1 and 3.2 for definitions of the independent variables 


\subsection{Regression Models - South Region}

The regression models provided the poorest fits for the southern region. Because of the small variation among the different watersheds because of the small variation of $\mathrm{R}$ and $\mathrm{t}_{\mathrm{c}}$. Referring to the optimized $\mathrm{R}$ values in Table 6.2, it is clear that the storage effects of the watersheds vary little across the southern region making this variable difficult to discriminate. The regression models for $\mathrm{R}$ do not contain any variables relating to slope, possibly because of the consistency (small variation) in the slope across the region. The variables selected to predict $\mathrm{R}$ are all based on stream network and basin shape parameters. The prediction of $t_{c}$ in the southern region shows a dependence on land cover/land use with the inclusion of the urban land cover and curve number parameters.

Table 6.5. Summary of best South Region regression equations.

\begin{tabular}{lccc} 
Regression Model & Transform & Scenario & $\mathbf{R}^{2}$ \\
\hline $\log (\boldsymbol{R})=$ & & & \\
$2.012+1.450 \log \left(\boldsymbol{L}_{\boldsymbol{c a}}\right)-2.361 \log (\boldsymbol{C})+1.215 \log \left(\boldsymbol{R}_{f}\right)$ & Log Model 1 & 1 & 0.88 \\
& & & \\
$\log \left(\boldsymbol{t}_{\boldsymbol{c}}\right)=$ & & & \\
$-3.283+0.266 \log (\boldsymbol{U} \boldsymbol{L} \boldsymbol{C})+2.693 \log (\boldsymbol{C N})+1.696 \log \left(\boldsymbol{R}_{f}\right)-$ & Log Model 1 & 1 & 0.95 \\
$0.568 \log (\boldsymbol{H})$ & Log Model 1 & 2 & 0.69 \\
\hline $\log \left(\boldsymbol{t}_{\boldsymbol{c}}\right)=-3.503+0.179 \log (\boldsymbol{U} \boldsymbol{L C})+2.205 \log (\boldsymbol{C N})$ & & \\
\hline
\end{tabular}

All variables are log base 10 transformed.

Refer to Tables 3.1 and 3.2 for definitions of the independent variables

\subsection{Regression Models - Statewide}

The statewide regression equations were developed for two reasons. The first reason was to illustrate, more clearly, the important geomorphologic characteristics for Indiana overall. Second, the statewide regression models could provide a more simple 
set of equations utilizing a larger sample size. The larger sample size used to develop the statewide equations make them less dependent on the specific variation found in the smaller regional equations. The statewide regressions do support the findings of the statistical analysis of the geomorphologic parameters. The slopes and depression storage characteristics were identified as distinct among the regions. The prediction of $\mathrm{R}$ supports this by utilizing the $10-85 \%$ slope (Slope) and the percentage of sinks (Sinks). The $t_{c}$ regression model incorporates similar slope and depression storage related characteristics by including the average grid slope $\left(L_{s}\right)$ and percentage of water/wetland features (Water), but it also relies on basin length $\left(\mathrm{L}_{\mathrm{b}}\right)$. The use of basin length follows conventional wisdom that some type of hydraulic length is necessary to calculate $t_{c}$.

Table 6.6. Summary of best Statewide regression equations.

\begin{tabular}{lccc} 
Regression Model & Transform & Scenario & $\mathbf{R}^{2}$ \\
\hline $\log (\boldsymbol{R})=1.456-0.773 \log ($ Slope $)+0.382 \log ($ Sinks $)$ & Log Model 1 & 1 & 0.70 \\
$\log \left(\boldsymbol{t}_{\boldsymbol{c}}\right)=$ & & & \\
$-2.176+0.639 \log \left(\boldsymbol{L}_{\boldsymbol{b}}\right)-0.307 \log \left(\boldsymbol{L}_{\boldsymbol{s}}\right)+0.160 \log ($ Water $)$ & Log Model 1 & 1 & 0.62 \\
\hline
\end{tabular}

All variables are $\log$ base 10 transformed.

Refer to Tables 3.1 and 3.2 for definitions of the independent variables

\subsection{Summary of Regression Models}

The geomorphological parameters selected for the regional regressions vary greatly from region to region. Several parameters do show up frequently, namely : $\mathrm{C}_{\mathrm{f}}$, $\mathrm{R}_{\mathrm{f}}, \mathrm{ULC}$, and Slope. For the northern region $\mathrm{C}_{\mathrm{f}}$ is used in both regressions ( $t_{\mathrm{c}}$ and $\mathrm{R}$ ). Stream frequency $\left(\mathrm{C}_{\mathrm{f}}\right)$ was calculated as the total number of streams per unit area. The Fineness ratio $\left(\mathrm{R}_{\mathrm{f}}\right)$ was calculated as the ratio of channel lengths to the length of basin 
perimeter. The incorporation of this parameter shows that the stream network characteristics are important factors for calculating the Clark parameters within each region. The central region equations both incorporate a slope parameter which would indicate the central region is a transition region where watersheds nearer the south may exhibit higher slopes versus watersheds nearer the north. Urban land cover also has an influence on the $t_{c}$. This is to be expected because of the watersheds near Indianapolis used in this study. Equations for the southern region both include $\mathrm{R}_{\mathrm{f}}$ which again indicates the importance of stream network characteristics. The regression equations for $t_{c}$ and $R$ across the entire state support the statistical findings of the previous sections. Slope appears to be the most important independent variable distinguishing watersheds across the state from north to south, confirming lower slopes increase the $t_{c}$ and $\mathrm{R}$. The Clark storage, $\mathrm{R}$, is also impacted by the percentage of depression storage features. The positive correlation shows the increase in depression storage increases the Clark storage coefficient. Basin length, $\mathrm{L}_{b}$, shows a positive correlation to $t_{c}$, which would be similar to other methods of $t_{c}$ computation, where hydraulic or main channel length is an important factor. After analysis of the results from Scenario 1 and 2 the equations from the Log Model 1 - Scenario 1 were selected for validation (Table 6.6).

The performance of the developed regression equations was tested in two ways for this study. First, the regression equations (regionalized and statewide) were used to estimate average values of $t_{c}$ and $R$. The average Clark parameters for all watersheds used in regression model development were compared to the optimized average values. 
Plots of each are included in Figures 6.14-6.21. Overall there is a good agreement of calculated and observed values. The plot with the largest deviation from the 1:1 line was the average values for $\mathrm{R}$ in the southern region. This is possibly due to the small variation in the optimized average $\mathrm{R}$ values in the south, thus making it difficult to fit a regression to a set of closely grouped points. The regression equation for the entire state showed a higher deviation in optimized and calculated values as well. The regression models for the north and central regions performed well for both Clark parameters. This is especially important because estimating the watershed storage effects in the north was the focus of this study, since current SUH methods are not performing well for low slope watersheds.

Table 6.7. Regression equations selected for implementation

\begin{tabular}{|c|c|}
\hline Models & Log Model 1 - Scenario 1 \\
\hline \multicolumn{2}{|l|}{ North } \\
\hline & $\log R=1.139-0.164 \log (U L C)-0.819 \log \left(C_{f}\right)$ \\
\hline & $\log \boldsymbol{t}_{c}=-3.355+1.677 \log (\boldsymbol{C D A})+1.369 \log \left(C_{f}\right)+0.396 \log (G)$ \\
\hline \multicolumn{2}{|l|}{ Central } \\
\hline & $\log R=1.727-2.722 \log \left(R_{f}\right)-0.932 \log ($ Slope $)$ \\
\hline & $\log t_{c}=-1.944-0.927 \log \left(L_{s}\right)+0.956 \log (H)-0.125 \log (U L C)$ \\
\hline \multicolumn{2}{|l|}{ South } \\
\hline & $\log R=2.012+1.450 \log \left(L_{c a}\right)-2.361 \log (C)+1.215 \log \left(R_{f}\right)$ \\
\hline & $\log t_{c}=-3.283+0.266 \log (U L C)+2.693 \log (C N)+1.696 \log \left(R_{f}\right)-0.568 \log (H)$ \\
\hline \multicolumn{2}{|c|}{ Statewide } \\
\hline & $\log R=1.456-0.773 \log ($ Slope $)+0.382 \log ($ Sinks $)$ \\
\hline & $\log t_{c}=-2.176+0.639 \log \left(L_{b}\right)-0.307 \log \left(L_{s}\right)+0.160 \log ($ Water $)$ \\
\hline
\end{tabular}

All variables are log base 10 transformed.

Refer to Tables 3.1 and 3.2 for definitions of the independent variables 

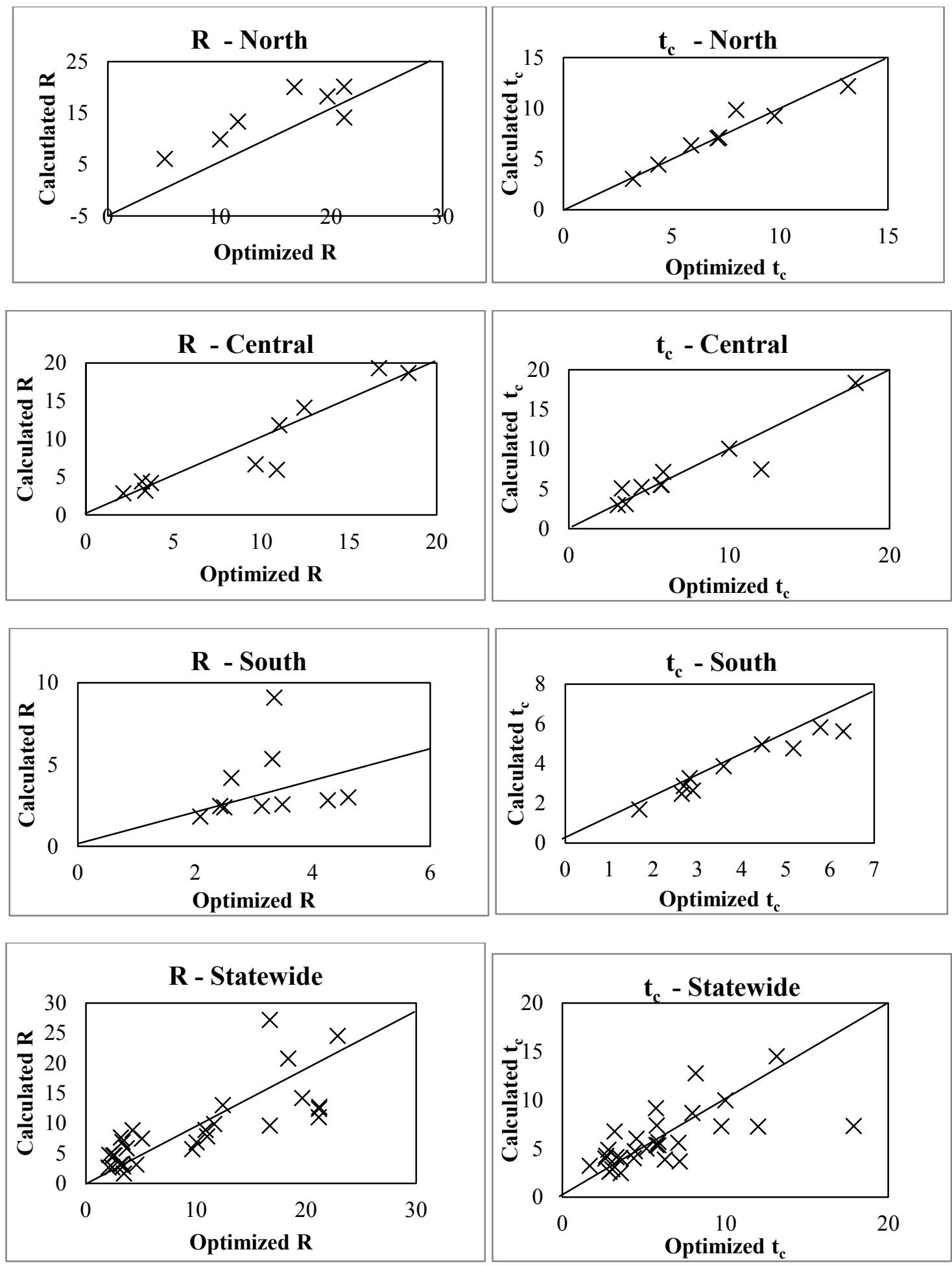

Figures $6.14-6.21$. Optimized vs Calculated $R$ and $t_{c}$ 


\subsection{Evaluation of Regression Equations}

Data for 7 of the 30 study watersheds were used for a application trial of a rainfall-runoff event that was not used in optimization. Watersheds selected for implementation included: Forker Creek, Rimmel Branch, and Iroqouis River from the northern region, Kokomo Creek and Little Buck Creek from the central region, and Hall creek and West Fork Blue River of the southern region. These were selected to best represent the geomorphological characteristics encountered throughout the state. Figure 6.22 is a map showing the location of each watershed and Table 6.7 lists some descriptive geomorphologic characteristics. Rainfall-runoff events were selected with the same criteria as discussed in Section 3.3.

Table 6.8. Study areas selected for implementation

\begin{tabular}{lccccc}
\hline Station Name & $\begin{array}{c}\text { Station } \\
\text { Number }\end{array}$ & Region & $\begin{array}{c}\text { Area } \\
\left(\mathrm{mi}^{2}\right)\end{array}$ & $\begin{array}{c}\text { Main } \\
\text { Channel } \\
\text { Length } \\
(\mathrm{mi})\end{array}$ & $\begin{array}{c}\text { Main } \\
\text { Channel } \\
\text { Slope } \\
(\mathrm{ft} / \mathrm{mi})\end{array}$ \\
\hline FORKER CREEK & & & & & \\
RIMMELL BRANCH & 4100252 & North & 19.2 & 10.95 & 9.7 \\
IROQUOIS RIVER & 4100295 & North & 10.7 & 7.32 & 12.1 \\
& 5521000 & North & 35.6 & 10.42 & 3.0 \\
KOKOMO CREEK & 3333600 & Central & 24.7 & 13.66 & 4.4 \\
LITTLE BUCK CREEK & 3353637 & Central & 17.0 & 12.29 & 14.2 \\
& & & & & \\
WEST FORK BLUE RIVER & 3302680 & South & 19.0 & 8.96 & 24.9 \\
HALL CREEK & 3375800 & South & 21.8 & 8.73 & 17.7 \\
& & & & & \\
\hline
\end{tabular}

HEC-HMS was used as in the application of the Clark parameter regression equations. The loss method selected was initial and constant loss rate and baseflow was separated before observed hydrographs were added to HEC-HMS. Initial and constant 
loss rates were calculated so precipitation excess equaled direct runoff of the observed hydrograph. This was to ensure all hydrographs computed were of the same volume for proper comparison. Application differed from optimization in that three transform methods (SUH methods) were utilized.

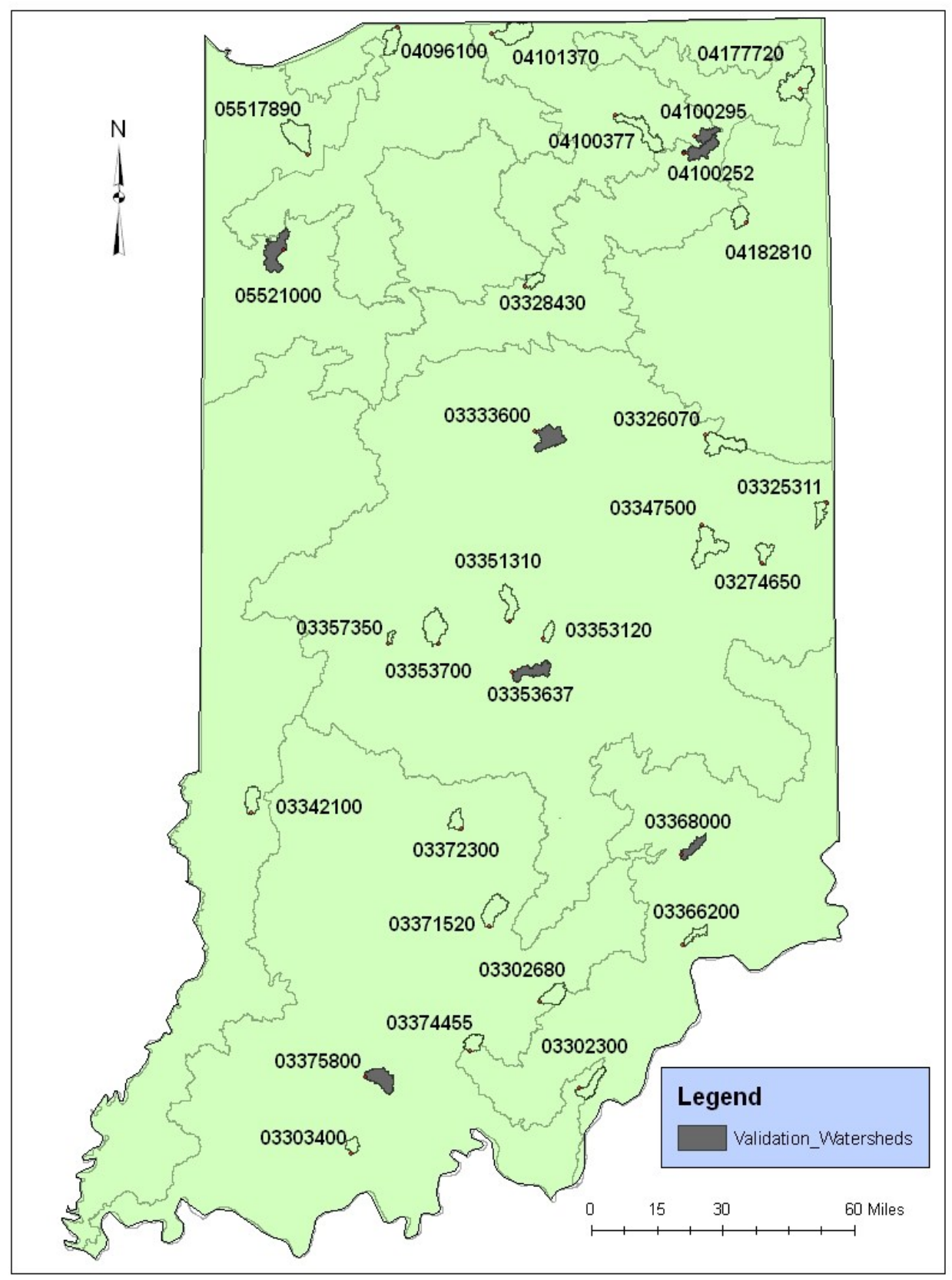

Figure 6.22. Location of validation study areas 
Run 1 was performed using the Clark SUH method, where the Clark SUH parameters were estimated using the appropriate regional equations discussed previously. The second run utilized the statewide regression equation (Clark2) to estimate the Clark SUH parameters. Run 3 was computed using the standard NRCS method, where the basin lag is calculated as:

$t_{\text {lag }}=\frac{L^{0.8}\left(S+1^{0.7}\right)}{1900 \sqrt{Y}}$

where $t_{\text {lag }}$ is the lag time in hours, $\mathrm{L}$ is the hydraulic length of the watershed in feet, $\mathrm{Y}$ is watershed slope in percent, and $\mathrm{S}$ is maximum retention storage in inches defined as:

$S=\frac{1000}{C N}-10$

where $\mathrm{CN}$ is the curve number based on the land use and soil type. The basin lag was calculated using HEC-GeoHMS to calculate the curve number grid. The NRCS method was chosen because from experience the curve number is not sufficient for estimating the detention storage or slope effects of northern watersheds.

Results from the 7 new events are in Figures 6.23-6.29, and Table 6.8 lists summary statistics comparing the observed $\mathrm{Q}_{\mathrm{p}}$ and $\mathrm{t}_{\mathrm{p}}$ to each SUH method and the relative error calculated as:

Relative Error $\left(Q_{p}\right)=\frac{Q_{p, \text { observed }}-Q_{p, \text { predicted }}}{Q_{p, \text { observed }}}$

Relative Error $\left(t_{p}\right)=\frac{t_{p, \text { observed }}-t_{p, \text { predicted }}}{t_{p, \text { observed }}}$ 
Overall the results are very revealing about the ability of the Clark SUH to account for the storage effects in northern Indiana. Specifically, the events for Rimmel Branch, Iroquois River, Kokomo Creek, and Little Buck Creek all show the ability of the Clark regression equations to predict the $\mathrm{Q}_{\mathrm{p}}$ and $\mathrm{t}_{\mathrm{p}}$. From a graphical comparison of the Forker Creek and Rimmel Branch events, it is apparent that the ability of the Clark SUH method to account for watershed storage and mirror the observed data is far superior to the NRCS method. The Forker Creek is by far the most extreme event considered from the aspect of increased storage and time of concentration. The events from the central region watersheds represent the transitional characteristics of the regions. Kokomo Creek has much lower slopes and high storage effects. Little Buck Creek is located near Indianapolis, and has geomorphology affected by urban development (45\% urban land cover). In both cases (Kokomo Creek and Little Buck Creek) peak flows were estimated within $18 \%$ and $10 \%$, and $t_{p}$ was estimated within $7 \%$ and $45 \%$ respectively. Graphically in both events the Clark SUH method matched the observed data well. A comparison of the calculated $\mathrm{R}$ and $\mathrm{t}_{\mathrm{c}} \mathrm{used}$ in the application were compared to optimized values located in Table 6.9. The optimized values were only optimized for the storm events used in the application of the regression equations. 
Table 6.9. Implementation Results

\begin{tabular}{|c|c|c|c|c|c|c|}
\hline Name & $\begin{array}{l}\text { Station } \\
\text { No. }\end{array}$ & Run & $\begin{array}{c}\mathrm{Q}_{\mathrm{p}} \\
(\mathrm{cfs})\end{array}$ & $\begin{array}{l}\text { Relative } \\
\text { Error }\end{array}$ & $\begin{array}{c}t_{\mathrm{p}} \\
(\mathrm{min})\end{array}$ & $\begin{array}{l}\text { Relative } \\
\text { Error }\end{array}$ \\
\hline $\begin{array}{l}\text { Forker Creek } \\
\text { (North) }\end{array}$ & 04100252 & $\begin{array}{l}\text { Observed } \\
\text { Clark } \\
\text { Clark2 } \\
\text { NRCS }\end{array}$ & $\begin{array}{c}71 \\
112 \\
229 \\
529\end{array}$ & $\begin{array}{l}-0.37 \\
-0.69 \\
-0.87\end{array}$ & $\begin{array}{c}2250 \\
1620 \\
1080 \\
885\end{array}$ & $\begin{array}{l}0.39 \\
1.08 \\
1.54\end{array}$ \\
\hline $\begin{array}{l}\text { Rimmel Branch } \\
\text { (North) }\end{array}$ & 04100295 & $\begin{array}{l}\text { Observed } \\
\text { Clark } \\
\text { Clark2 } \\
\text { NRCS }\end{array}$ & $\begin{array}{l}107 \\
135 \\
176 \\
515\end{array}$ & $\begin{array}{l}-0.21 \\
-0.39 \\
-0.79\end{array}$ & $\begin{array}{l}390 \\
570 \\
495 \\
315\end{array}$ & $\begin{array}{c}-0.32 \\
-0.21 \\
0.24\end{array}$ \\
\hline $\begin{array}{l}\text { Iroquois River } \\
\text { (North) }\end{array}$ & 05521000 & $\begin{array}{l}\text { Observed } \\
\text { Clark } \\
\text { Clark2 } \\
\text { NRCS }\end{array}$ & $\begin{array}{l}114 \\
119 \\
123 \\
283\end{array}$ & $\begin{array}{l}-0.04 \\
-0.07 \\
-0.60\end{array}$ & $\begin{array}{l}2190 \\
2175 \\
2055 \\
1995\end{array}$ & $\begin{array}{l}0.01 \\
0.07 \\
0.10\end{array}$ \\
\hline $\begin{array}{l}\text { Kokomo Creek } \\
\text { (Central) }\end{array}$ & 03333600 & $\begin{array}{l}\text { Observed } \\
\text { Clark } \\
\text { Clark2 } \\
\text { NRCS }\end{array}$ & $\begin{array}{l}285 \\
337 \\
315 \\
644\end{array}$ & $\begin{array}{l}-0.15 \\
-0.10 \\
-0.56\end{array}$ & $\begin{array}{l}2235 \\
2385 \\
2400 \\
2160\end{array}$ & $\begin{array}{c}-0.06 \\
-0.07 \\
0.03\end{array}$ \\
\hline $\begin{array}{l}\text { Little Buck } \\
\text { Creek } \\
\text { (Central) }\end{array}$ & 03353637 & $\begin{array}{l}\text { Observed } \\
\text { Clark } \\
\text { Clark2 } \\
\text { NRCS }\end{array}$ & $\begin{array}{c}732 \\
652 \\
701 \\
1240\end{array}$ & $\begin{array}{c}0.12 \\
0.04 \\
-0.41\end{array}$ & $\begin{array}{l}465 \\
675 \\
690 \\
540\end{array}$ & $\begin{array}{l}-0.31 \\
-0.33 \\
-0.14\end{array}$ \\
\hline $\begin{array}{l}\text { West Fork Blue } \\
\text { River } \\
\text { (South) }\end{array}$ & 03302680 & $\begin{array}{l}\text { Observed } \\
\text { Clark } \\
\text { Clark2 } \\
\text { NRCS }\end{array}$ & $\begin{array}{l}359 \\
402 \\
460 \\
430\end{array}$ & $\begin{array}{l}-0.11 \\
-0.22 \\
-0.17\end{array}$ & $\begin{array}{l}255 \\
435 \\
375 \\
285\end{array}$ & $\begin{array}{l}-0.41 \\
-0.32 \\
-0.11\end{array}$ \\
\hline $\begin{array}{l}\text { Hall Creek } \\
\text { (South) }\end{array}$ & 03375800 & $\begin{array}{l}\text { Observed } \\
\text { Clark } \\
\text { Clark2 } \\
\text { NRCS }\end{array}$ & $\begin{array}{l}831 \\
812 \\
593 \\
923\end{array}$ & $\begin{array}{c}0.02 \\
0.40 \\
-0.10\end{array}$ & $\begin{array}{l}240 \\
465 \\
555 \\
405\end{array}$ & $\begin{array}{l}-0.48 \\
-0.57 \\
-0.41\end{array}$ \\
\hline
\end{tabular}

Clark2 - Clark parameters calculated with state regression equation 
Table 6.10. Calculated and Optimized Clark values

\begin{tabular}{lcccccc}
\hline Station Name & $\begin{array}{c}\text { Station } \\
\text { Number }\end{array}$ & Region & $\begin{array}{c}\text { Calc } \\
\mathrm{R}(\mathrm{hrs})\end{array}$ & $\begin{array}{c}\text { Opt } \\
\mathrm{R}(\mathrm{hrs})\end{array}$ & $\begin{array}{c}\text { Calc } \\
\mathrm{t}_{\mathrm{c}}(\mathrm{hrs})\end{array}$ & $\begin{array}{c}\text { Opt } \\
\mathrm{t}_{\mathrm{c}} \\
(\mathrm{hrs})\end{array}$ \\
\hline FORKER CREEK & 4100252 & North & 25.9 & 29.3 & 9.2 & 8.7 \\
$\begin{array}{l}\text { RIMMELL } \\
\text { BRANCH }\end{array}$ & 4100295 & North & 13.3 & 14.6 & 6.3 & 2.5 \\
$\begin{array}{l}\text { IROQUOIS RIVER } \\
\text { KOKOMO CREEK }\end{array}$ & 5521000 & North & 20.0 & 20.3 & 16.5 & 19.0 \\
$\begin{array}{l}\text { LITTLE BUCK } \\
\text { CREEK }\end{array}$ & 3333600 & Central & 18.7 & 22.9 & 10.1 & 5.7 \\
$\begin{array}{l}\text { WEST FORK BLUE } \\
\text { RIVER }\end{array}$ & 3353637 & Central & 6.6 & 5.1 & 5.2 & 3.9 \\
HALL CREEK & 3302680 & South & 2.5 & 4.4 & 5.6 & 3.0 \\
& 3375800 & South & 2.4 & 3.1 & 3.3 & 3.8 \\
\hline
\end{tabular}

Calculated values are from equations in Table 6.6

Optimized values are results from new events only

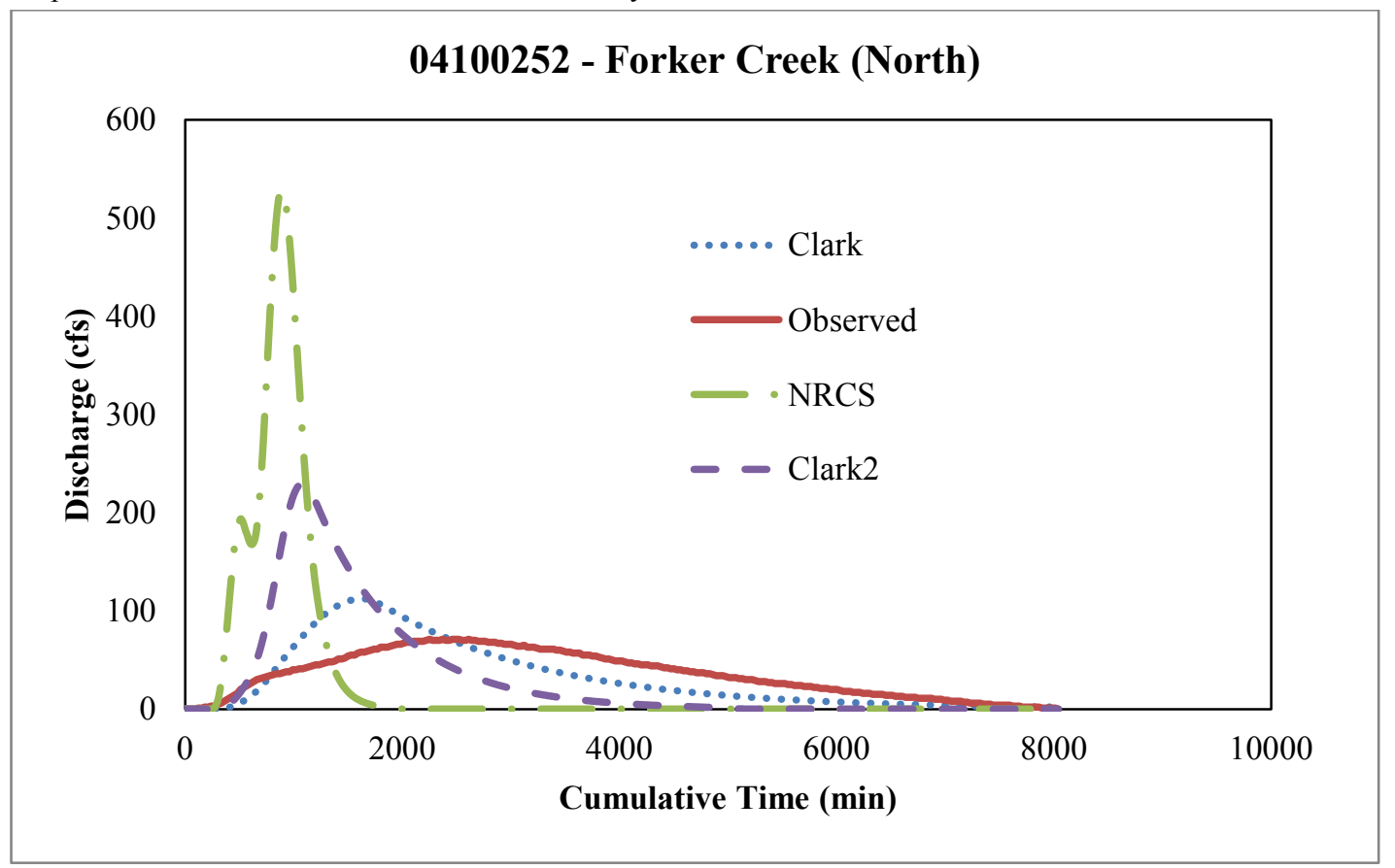

Figure 6.23. Results for 04100252 - Forker Creek 


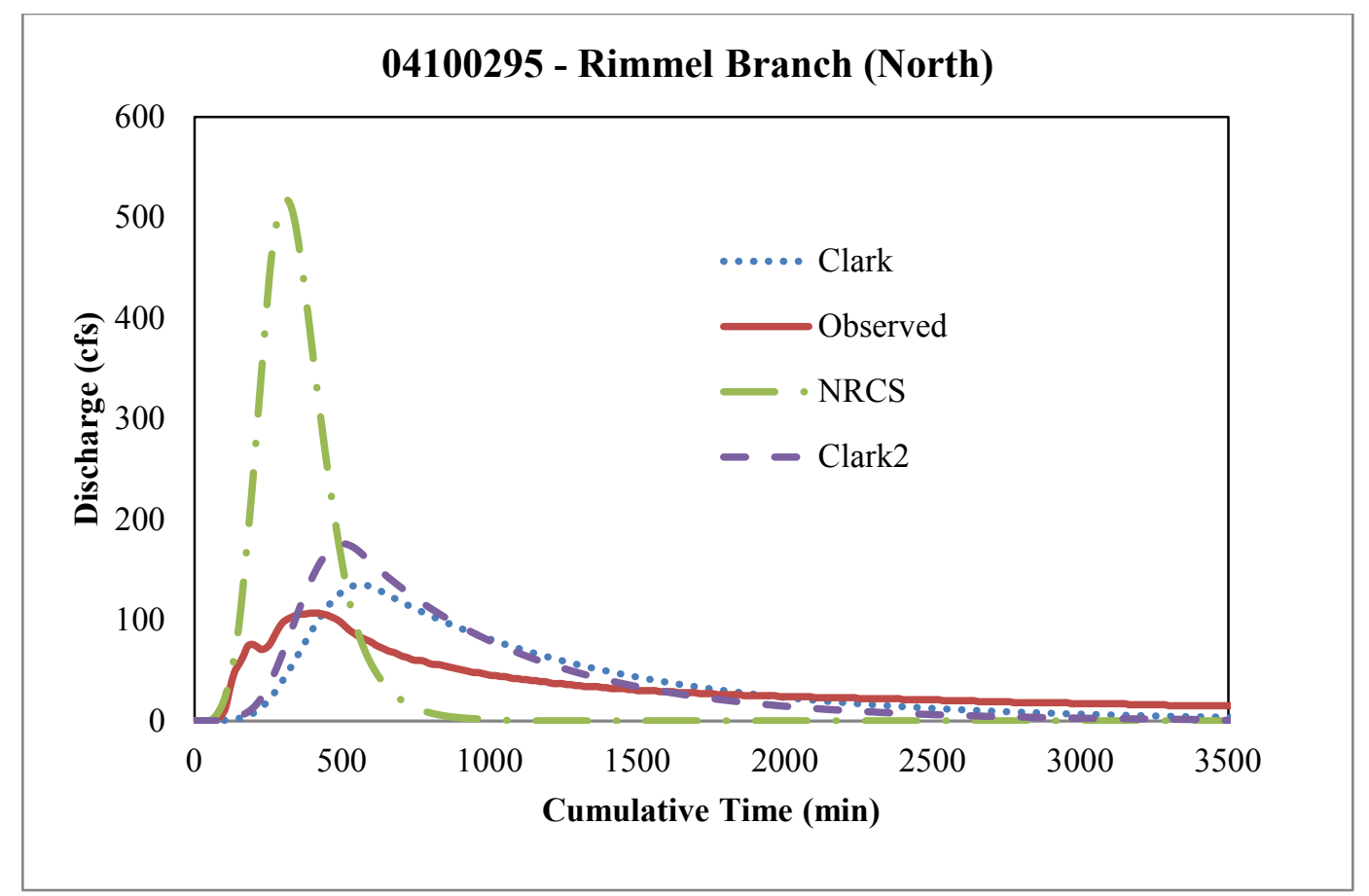

Figure 6.24. Results for 04100295 - Rimmel Branch

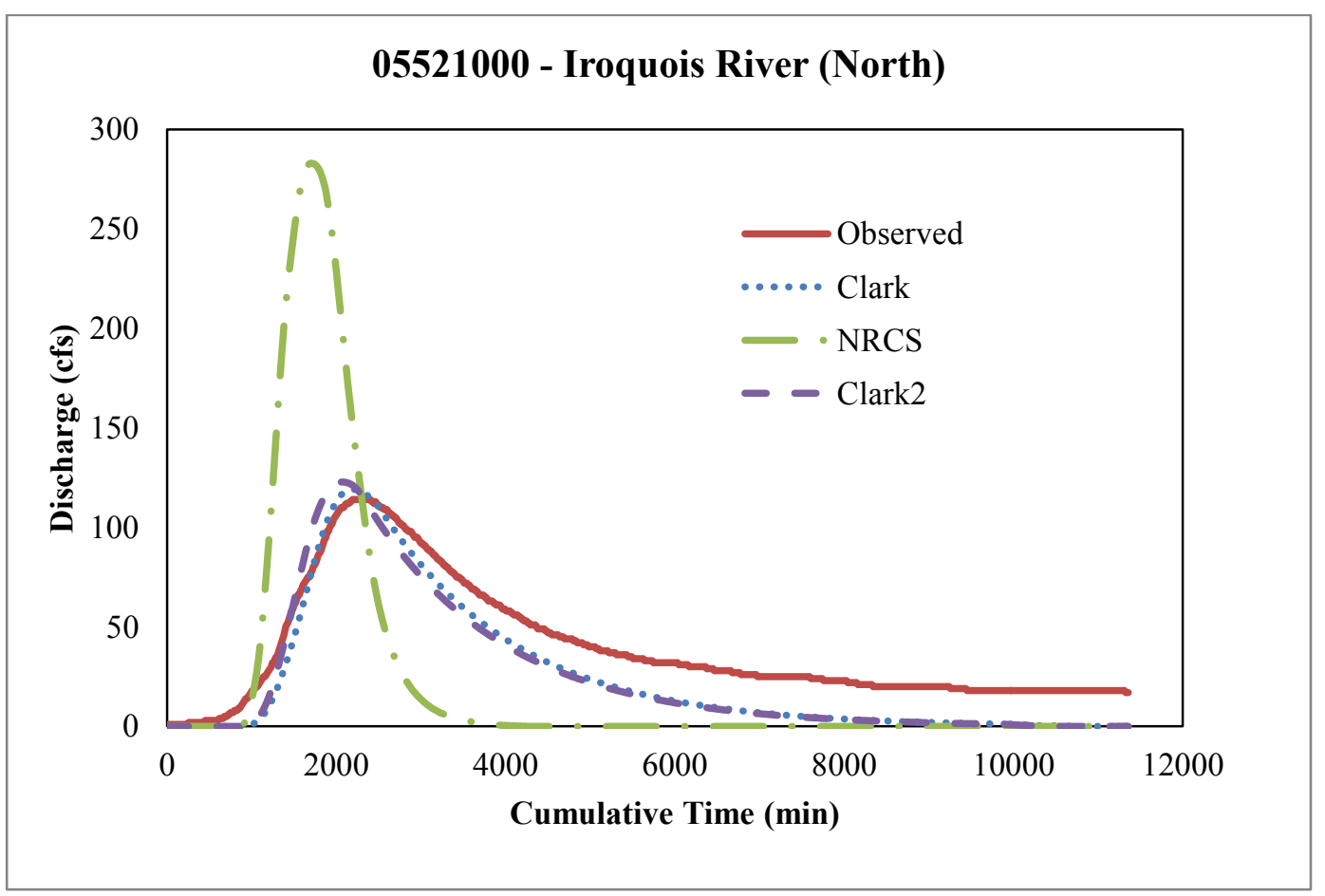

Figure 6.25. Results for 05521000 - Iroqouis River 


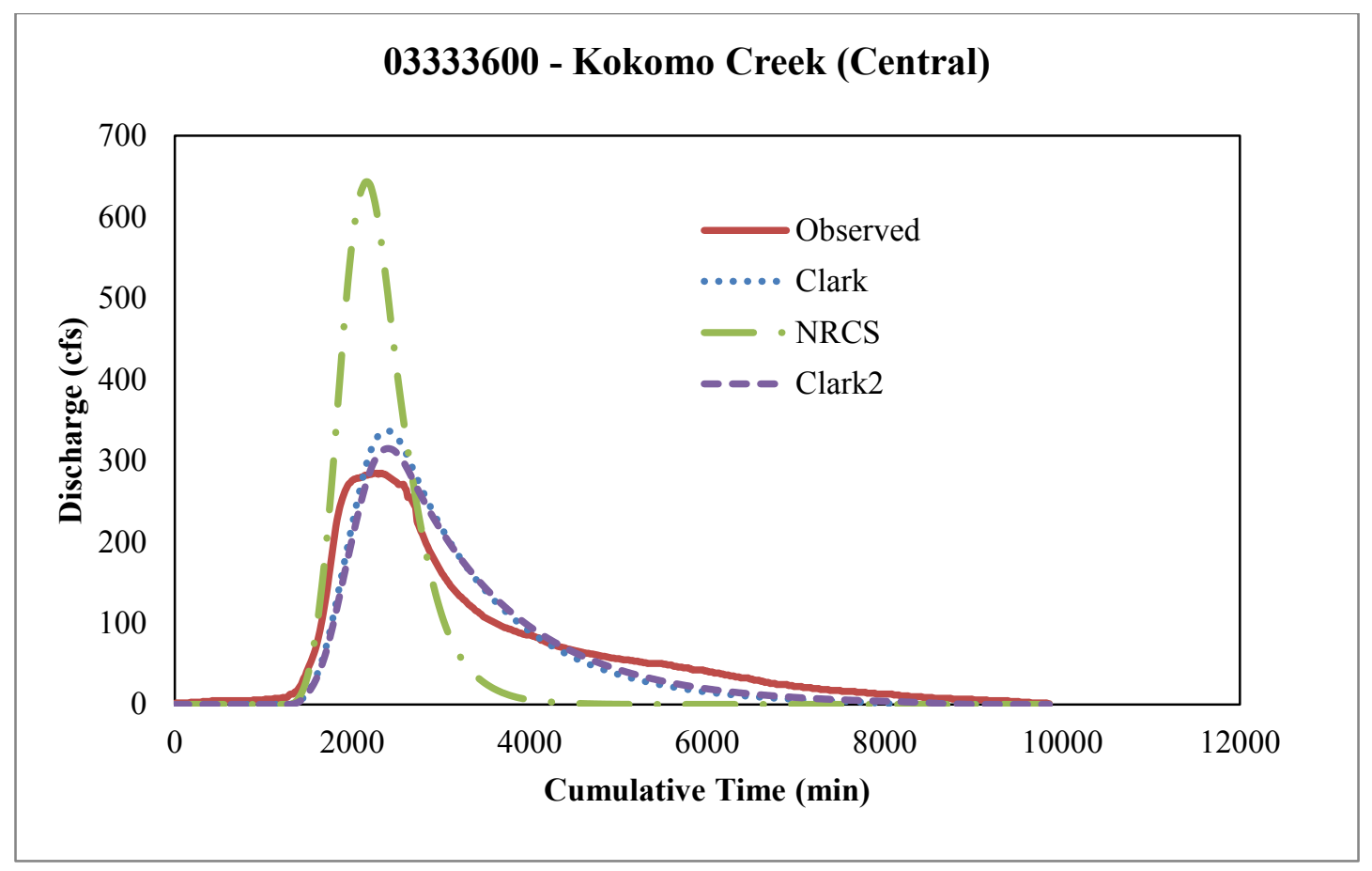

Figure 6.26. Results for 03333600 - Kokomo Creek

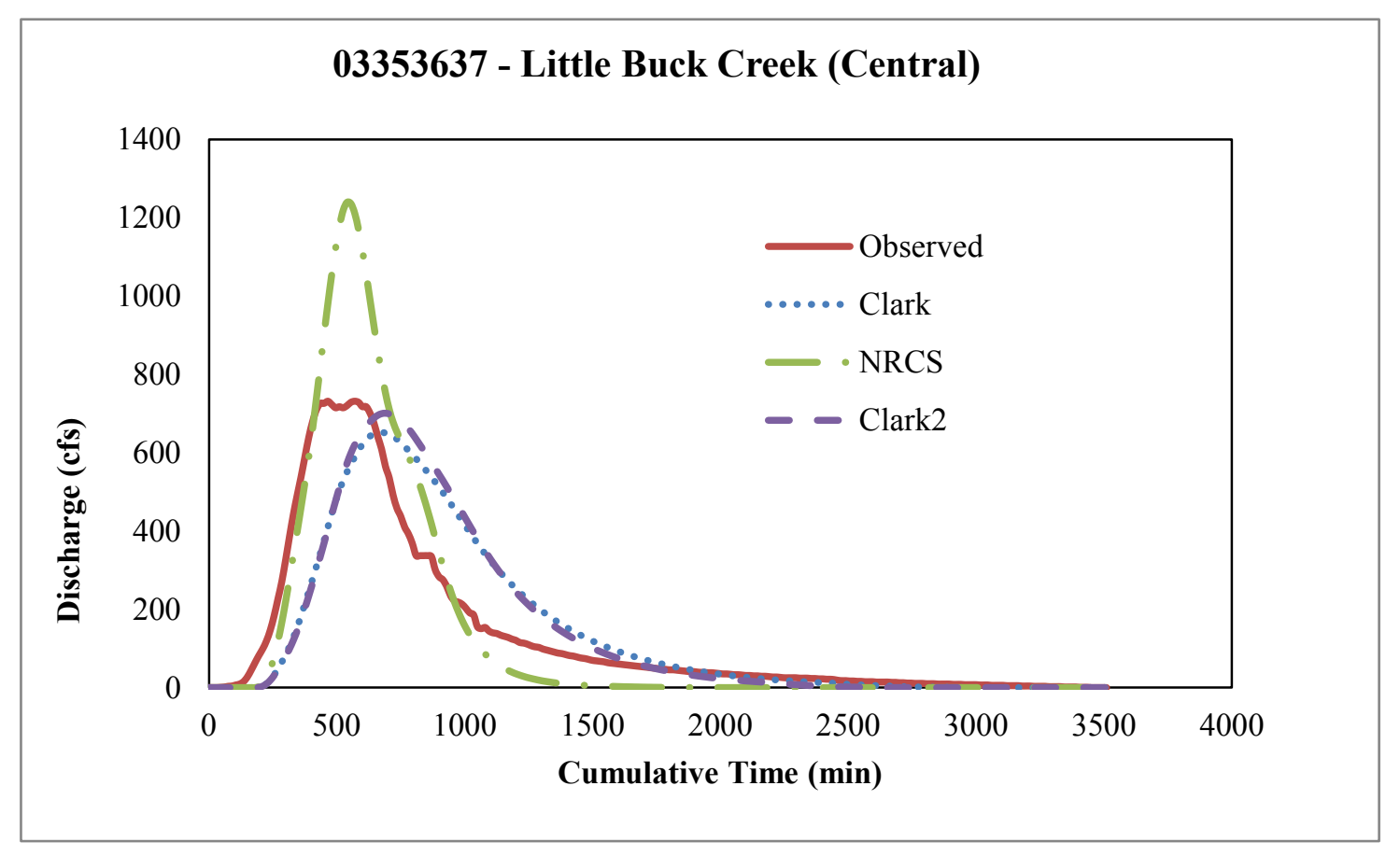

Figure 6.27. Results for 03353637 - Little Buck Creek 
For the southern region (West Fork Blue River and Hall Creek) results were more varied. Both the NRCS and Clark methods performed equally well. This supports the assumption that the NRCS method is sufficient for southern Indiana. For both events in the southern watersheds $Q_{p}$ was estimated well by the NRCS and regional Clark regressions (error $< \pm 20 \%$ ). The statewide Clark estimates performed worst for the southern region. This is due to the larger variation associated with the Clark2 regression models. Peak times were difficult for both methods to match in the southern region. Overall the regional Clark estimates performed best.

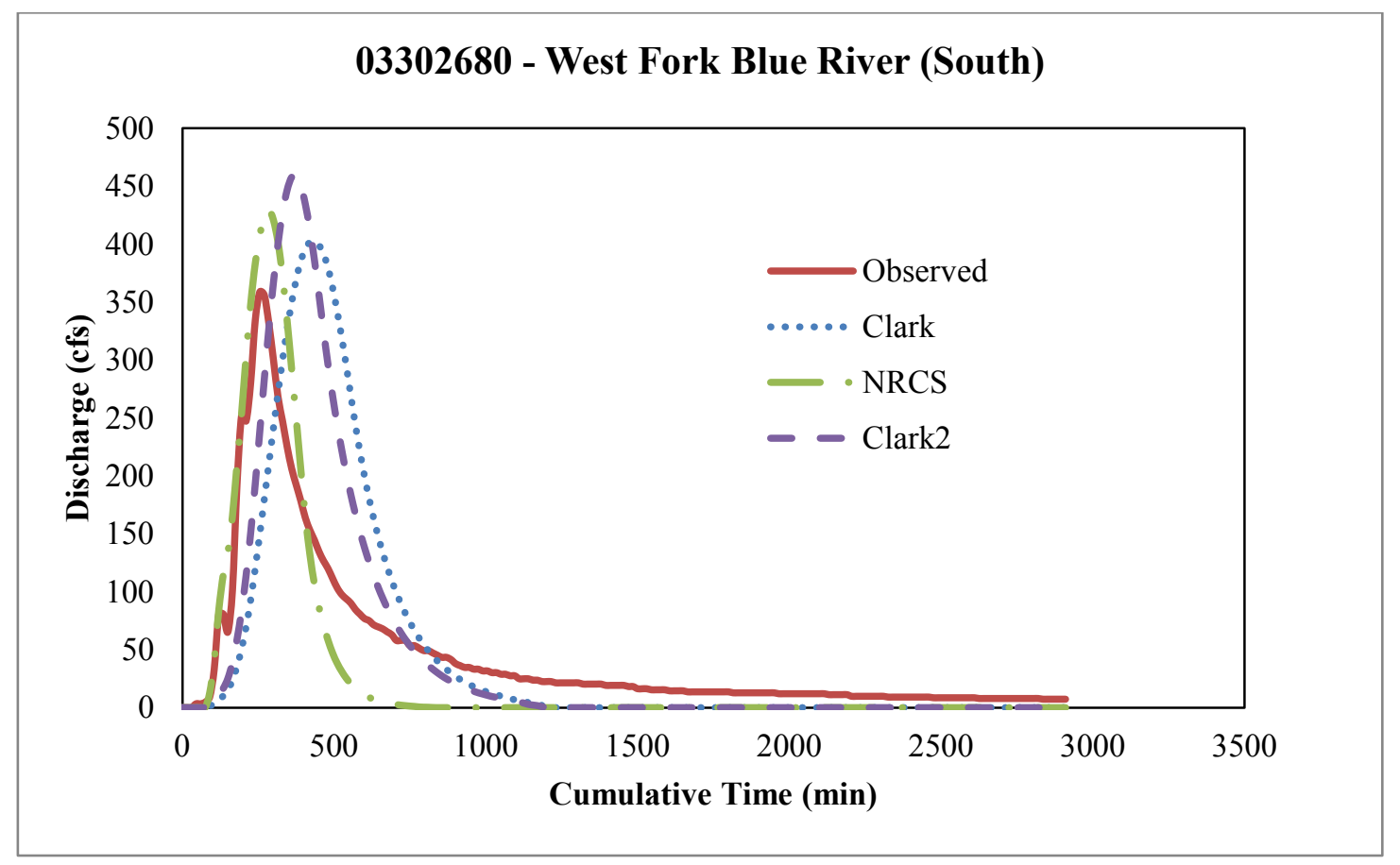

Figure 6.28. Results for 03302680 - West Fork Blue River 


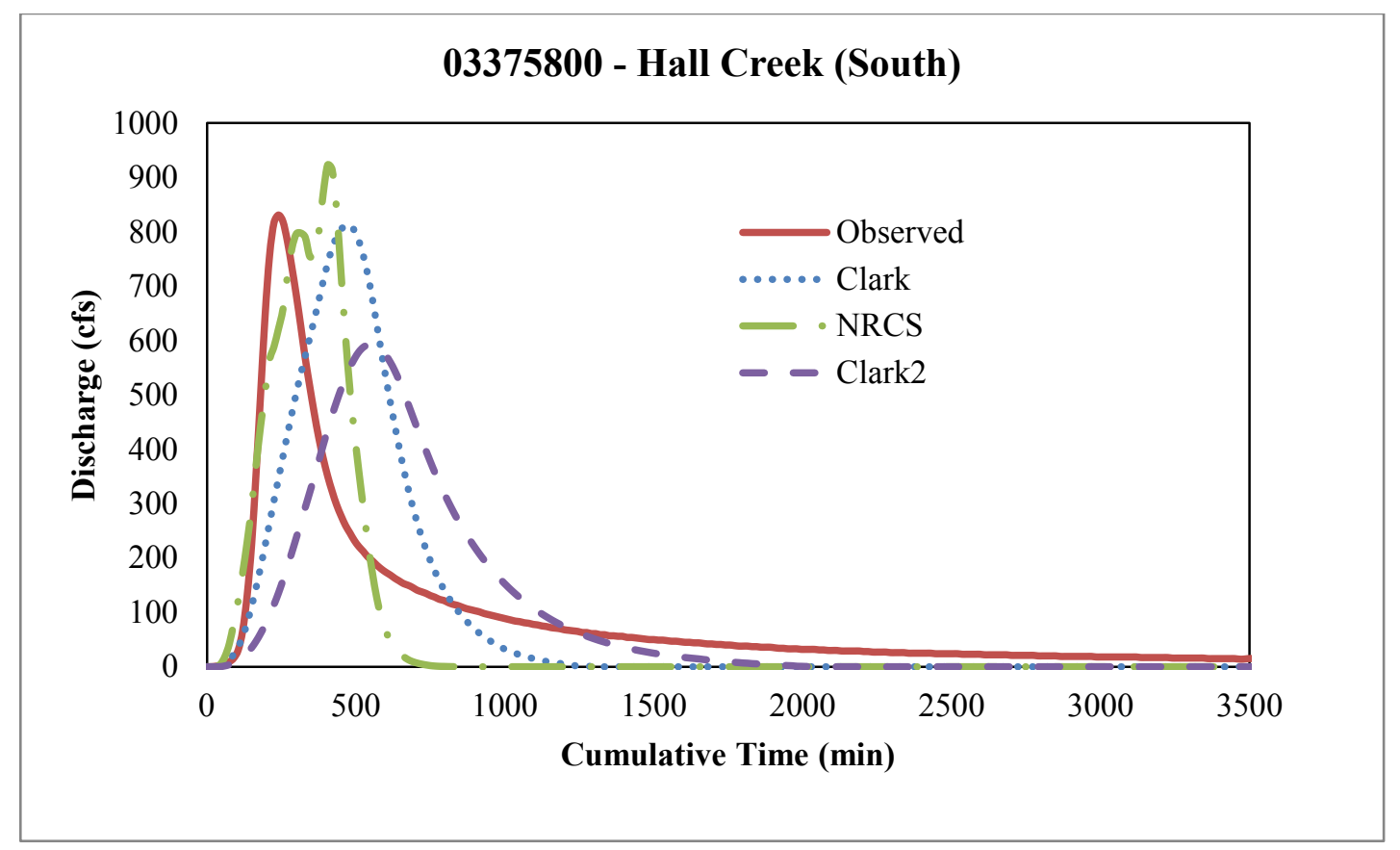

Figure 6.29. Results for 03375800 - Hall Creek 


\section{CHAPTER 7. CONCLUSIONS}

From this analysis, it can be said that northern and central Indiana are geomorphologically different from the southern region. Statistical analysis has shown a significant difference in the hydrology and geomorphology of northern Indiana compared to the sourthern region. It has been shown that watersheds in southern Indiana have statistically significantly higher slopes and peak flow rates. Also, northern Indiana's hydrology is affected by increased depression storage and lower slopes, and as a result has lower peak flows and increased times to peak. The central region appears to be a transition between the two geomorphologic extremes of the other two regions. These characteristics can be accounted for using SUH methods.

Specifically, the Clark SUH Method has been shown to account for the effects of low slopes and high depression storage using the parameters $t_{c}$ and $R$. The Clark SUH parameters can be estimated using geomorphologic parameters extracted using GIS tools. GIS techniques can improve the accuracy and ease of geomorphologic parameter extraction. Multiple linear regression can then be utilized to establish statistically significant relationships between the geomorphologic parameters and the Clark SUH parameters $t_{c}$ and R. Comparisons of the Clark and NRCS SUH methods show that the former's flexibility to incorporate varying of geomorphology and adjust the 
hydrograph's shape accordingly. In this manner the regression equations can extend the estimation of the Clark SUH parameters to ungauged watersheds of similar hydrology and geomorphology in Indiana.

The strength of these regression equations is their ease of use. Utilizing current GIS technology has become the standard in many hydrologic modeling applications. Geomorphologic parameters can be extracted accurately and quickly. Also, the regression equations can provide statistical information regarding confidence limits and measurable error of the Clark SUH parameter estimates. It is important to keep in mind, with any hydrologic method, an investigation into the results using this method is necessary before use in any design or modeling application. Comparison of this method with current established modeling methods is advised. Also, the regression equations should be applied only to watersheds with geomorphologic characteristics within the ranges used in this study 
LIST OF REFERENCES 


\section{LIST OF REFERENCES}

Abdulla, A.F., Lettenmaier, D.P., 1997. Development of regional parameter estimation equations for macroscale hydrologic model. Journal of Hydrology, 197 (1997) $230-257$

Bonnin, G., Todd, D., Lin, B., Parzybok, T., Yekta, M., and Riley, D. (2004). NOAA Atlas 14, Precipitation Frequency Atlas of the United States, Volume 1. U.S. Department of Commerce, National Oceanic and Atmospheric Administration, National Weather Service, Silver Spring, Maryland.

Chow, V.T., Maidment, D.R., Mays, L.W., 1988. Applied Hydrology. McGraw-Hill, New York.

Clark, C.O., 1945, Storage and the unit hydrograph: Transactions American Society of Civil Engineers, vol. 110, p. 1419-1488

Cleveland, T. G., Thompson, D. B., Fang, X., He, X., 2008, Synthesis of Unit Hydrograph from a Digital Elevation Model. Journal of Irrigation and Drainage Engineering, 134 (2), 212-221

Cody, R. P., Smith, J. K., 2006. Applied Statistics and the SAS Program Language. $5^{\text {th }}$ edition, Pearson Prentice Hall, New Jersey.

Davis, L. G. 1974. "Floods in Indiana: Technical Manual for Estimating Their Magnitude and Frequency”, U.S. Geological Survey Circular 710 Indianapolis, IN.

Draper, N.R., and Smith, H., 1981. Applied Regression Analysis. John Wiley, New York. 
Glatfelter, D. 1984. “Techniques for Estimating Magnitudes and Frequency of Floods of Streams in Indiana”, WRI 84-4134, USGS, Indianapolis, IN.

Gray, D.M., 1961. Synthetic unit hydrographs for small watersheds. Journal of Hydraulics Division, Proceedings of ASCE 87 (HY4), 33-54.

Gupta, V.K., Waymire, E., and Wang, C.T. 1980. “A representation of an instantaneous unit hydrograph from geomorphology." Water Resourses. Res., 16(5), 855-862

Hickok, R.B., Keppel, R.V., Rafferty, B.R., 1959 Hydrograph synthesis for small arid land watersheds. Agricultural Engineering 40 (10), 608-611

Huff, F.A., and Angel, J.R., 1992, Rainfall Frequency Atlas of the Midwest: Champaign, Ill., Midwestern Climate Center \& Illinois State Water Survey, Bulletin 71.

Jena, S.K., Tiwari, K.N., 2006 Modeling synthetic unit hydrograph parameters with geomorphologic parameters of watersheds. Journal of Hydrology 319 (2006) 1-14

Jin, C. 1992. "A deterministic gamma-type geomorphologic instantaneous unit hydrograph based on path types." Water Resour. Res., 28(2), 479-486.

Knipe D., Rao, A.R., 2005. Estimation of Peak Discharges of Indiana Streams by using Log Pearson (III) Distribution. FHWA/IN/JTRP-2005/1

Kutner, M. H., Nachtsheim, C. J., Neter, N., Li, W., 2005. Applied Linear Statistical Models. McGraw-Hill Irwin, Boston.

McCuen, Richard H., 2005. Hydrology Analysis and Design. Pearson Prentice Hall, New Jersey. 
Murphey, J.B., Wallace, D.E., Lane, L.J., 1977. Geomorphologic parameters predict hydrograph characteristics in the southwest. Water Resources Bulletin 13 (1), 25-38.

Rao, A. R., 2004. Regionalization of Indiana Watersheds for Flood Flow Predictions Phase I: Studies in Regionalization of Indiana Watersheds. FHWA/IN/JTRP$2002 / 2$

Rodriguez-Iturbe, I., Valdes, J.B., 1979. The geomorphologic structure of hydrologic response. Water Resources Research 15 (6), 1409-1420

Shamseldin, A. Y., and Nash, J. E. 1998. "The geomorphological unit hydrograph-A critical review.” Hydrology Earth Syst. Sci., 2(1), 1-8.

Sherman, L.K., 1932. Stream flow from rainfall by the unit-graph method. Engineering News Record 108, 501-505

Snyder, F.F., 1938, Synthetic unit-graphs: Transactions, American Geophysical Union, vol. 19 , p. $447-454$.

Soil Conservation Service, 1985, National engineering handbook, section 4. hydrology: Washington, D.C., U.S. Department of Agriculture, variable pagination.

Straub, T.D., Melching, C.C., Kocher, K.E., 2000. Equations for estimating Clark unithydrograph parameters for small rural watersheds in Illinois. Urbana, Il, U.S.

Geological Survey, Water Resources Investigations Report 00-4184

U.S. Army Corp of Engineers, 1990, HEC-1 flood hydrograph package, user's manual:

Davis, Calif., U.S. Army Corp of Engineers Hydrologic Engineering Center, variable pagination.

U.S. Army Corp of Engineers, 2000. Hydrologic modeling system HEC-HMS Technical Reference Manual: United States Army Corp of Engineers Hydraulics Engineering Center, Davis, California, variable pagination 
Valdes, J.B., Fiallo, Y., Rodriguez-Iturbe, I., 1979. A rainfall-runoff analysis of the geomorphologic IUH. Water Resources Research 15 (6), 1421-1

Viessman, W., Jr., Lewis, G.L., and Knapp, J.W., 1989, Introduction of hydrology, third edition: New York, Harper and Row Publishers, 780 p.

Wilcoxon, F., 1945. Individual Comparisons by Ranking Methods. International Biometric Society Vol.1, No. 6, pp. 80-83. 
APPENDICES 
Appendix A

Table A.1. Scenario 1- Log Transformed R Regression for North Region

\begin{tabular}{lr}
\hline \multicolumn{2}{c}{ Regression Statistics } \\
\hline Multiple \\
$\mathrm{R}$ & 0.93 \\
$\mathrm{R}^{2}$ & 0.86 \\
Adj R & 0.82 \\
Std Error & 0.10 \\
Obs & 10 \\
\hline
\end{tabular}

ANOVA

\begin{tabular}{|c|c|c|c|c|}
\hline & $d f$ & $S S$ & $M S$ & $F$ \\
\hline Regressio & & & & 18.757 \\
\hline $\mathrm{n}$ & 2 & 0.3427 & 0.1713 & 6 \\
\hline Residual & 7 & 0.0548 & 0.0091 & \\
\hline \multirow[t]{2}{*}{ Total } & 9 & 0.3975 & & \\
\hline & $\begin{array}{c}\text { Coefficient } \\
S\end{array}$ & $\begin{array}{c}\text { Std. } \\
\text { Error }\end{array}$ & t Stat & $\begin{array}{c}P- \\
\text { value }\end{array}$ \\
\hline Intercept & 1.139 & 0.034 & 33.759 & 0.000 \\
\hline UrbanLC & -0.164 & 0.035 & -4.701 & 0.003 \\
\hline $\mathrm{Cf}$ & -0.819 & 0.165 & -4.966 & 0.003 \\
\hline
\end{tabular}

\section{RESIDUAL OUTPUT}

\begin{tabular}{cccc}
\hline Obs & $\begin{array}{c}\text { Predicted } \\
\log (R)\end{array}$ & $\begin{array}{c}\text { Residual } \\
\text { s }\end{array}$ & $\begin{array}{c}\text { Std } \\
\text { Resid. }\end{array}$ \\
\hline 1 & 1.149 & 0.177 & 2.140 \\
2 & 0.992 & 0.011 & 0.136 \\
3 & 1.415 & -0.088 & -1.059 \\
4 & 1.125 & -0.057 & -0.688 \\
5 & 1.421 & -0.061 & -0.735 \\
6 & 1.303 & 0.023 & 0.278 \\
7 & 0.785 & -0.076 & -0.913 \\
8 & 1.259 & 0.035 & 0.424 \\
9 & 1.301 & 0.034 & 0.417 \\
\hline
\end{tabular}

Sig. F

0.0026

(1)

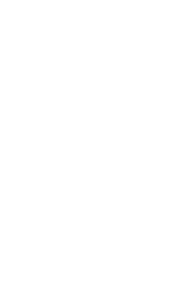

PROBABILITY

OUTPUT

\begin{tabular}{ccc}
\hline $\begin{array}{c}\text { Percentil } \\
e\end{array}$ & $\begin{array}{c}\log (R \\
)\end{array}$ & $R$ \\
\hline 5.56 & 0.71 & 5.12 \\
16.67 & 1.00 & 10.0 \\
27.78 & 1.07 & 11.6 \\
38.89 & 1.29 & 19.6 \\
50.00 & 1.33 & 21.1 \\
61.11 & 1.33 & 21.2 \\
72.22 & 1.33 & 21.2 \\
83.33 & 1.34 & 21.6 \\
94.44 & 1.36 & 22.9 \\
\hline
\end{tabular}


Table A.2. Linear Model - Scenerio 2 R Regression for North Region

\begin{tabular}{lr}
\hline \multicolumn{2}{c}{ Regression Statistics } \\
\hline Multiple R & 0.94 \\
$\mathrm{R}^{2}$ & 0.88 \\
Adj $^{2}$ & 0.84 \\
Std Error & 2.58 \\
Obs & 9 \\
\hline
\end{tabular}

\begin{tabular}{|c|c|c|c|c|c|}
\hline & $d f$ & $S S$ & $M S$ & $F$ & $\operatorname{Sig} F$ \\
\hline Regression & 2 & 293.665 & 146.832 & 21.987 & 0.002 \\
\hline Residual & 6 & 40.068 & 6.678 & & \\
\hline \multirow[t]{2}{*}{ Total } & 8 & 333.733 & & & \\
\hline & Coefficients & Std Error & $t$ Stat & $P$-value & \\
\hline Intercept & 27.009 & 1.802 & 14.993 & 0.000 & \\
\hline Slope & -1.665 & 0.268 & -6.205 & 0.001 & \\
\hline Water & 1.506 & 0.403 & 3.741 & 0.010 & \\
\hline
\end{tabular}

RESIDUAL

OUTPUT

\begin{tabular}{cccc}
\hline Obs & Predicted $R$ & Residuals & StdResid \\
\hline 1 & 17.16 & 4.04 & 1.80 \\
2 & 9.97 & 0.11 & 0.05 \\
3 & 21.74 & -0.51 & -0.23 \\
4 & 14.47 & -2.78 & -1.24 \\
5 & 23.73 & -0.83 & -0.37 \\
6 & 18.35 & 2.83 & 1.26 \\
7 & 6.26 & -1.14 & -0.51 \\
8 & 19.09 & 0.60 & 0.27 \\
9 & 23.99 & -2.32 & -1.04 \\
\hline
\end{tabular}

PROBABILITY

OUTPUT

\begin{tabular}{cc}
\hline Percentile & $R$ \\
\hline 5.56 & 5.12 \\
16.67 & 10.08 \\
27.78 & 11.69 \\
38.89 & 19.69 \\
50.00 & 21.18 \\
61.11 & 21.2 \\
72.22 & 21.23 \\
83.33 & 21.67 \\
94.44 & 22.9 \\
\hline
\end{tabular}


Table A.3. Log Model 1 - Scenerio $1 t_{c}$ Regression for North Region

\begin{tabular}{lr}
\hline \multicolumn{2}{c}{ Regression Statistics } \\
\hline Multiple \\
$\mathrm{R}$ & 0.98 \\
$\mathrm{R}^{2}$ & 0.97 \\
Adj $^{2}$ & 0.95 \\
Std Error & 0.05 \\
Obs. & 9 \\
\hline
\end{tabular}

\begin{tabular}{|c|c|c|c|c|c|}
\hline & $d f$ & $S S$ & $M S$ & $F$ & $\operatorname{Sig} F$ \\
\hline Regressio & & & & 53.12 & \\
\hline $\mathrm{n}$ & 3 & 0.398 & 0.133 & 6 & 0.0003 \\
\hline Residual & 5 & 0.012 & 0.002 & & \\
\hline Total & 8 & 0.411 & & & \\
\hline & $\begin{array}{c}\text { Coefficient } \\
s \\
\end{array}$ & $\begin{array}{c}\text { Std } \\
\text { Error }\end{array}$ & $t$ Stat & $\begin{array}{c}P- \\
\text { value }\end{array}$ & \\
\hline Intercept & -3.355 & 0.468 & 7.169 & 0.001 & \\
\hline ContDA & 1.677 & 0.184 & 9.109 & 0.000 & \\
\hline $\mathrm{Cf}$ & 1.369 & 0.223 & 6.152 & 0.002 & \\
\hline Gray & 0.396 & 0.069 & 5.740 & 0.002 & \\
\hline
\end{tabular}

RESIDUAL OUTPUT

\begin{tabular}{cccc}
\hline Obs. & $\begin{array}{c}\text { Pred } \\
\log (\mathrm{Tc})\end{array}$ & $\begin{array}{c}\text { Residual } \\
\text { s }\end{array}$ & $\begin{array}{c}\text { Std } \\
\text { Resid }\end{array}$ \\
\hline 1 & 0.480 & 0.028 & 0.706 \\
2 & 0.851 & 0.007 & 0.171 \\
3 & 0.966 & 0.024 & 0.600 \\
& & & - \\
4 & 0.802 & -0.031 & 0.782 \\
5 & 1.086 & 0.034 & 0.849 \\
6 & 0.847 & 0.007 & 0.174 \\
& & & - \\
7 & 0.648 & -0.005 & 0.126 \\
& & & - \\
8 & 0.993 & -0.091 & 2.291 \\
9 & 1.218 & 0.028 & 0.697 \\
\hline
\end{tabular}

PROBABILITY OUTPUT

\begin{tabular}{ccc}
\hline $\begin{array}{c}\text { Percentil } \\
e\end{array}$ & $\log (T c)$ & $T c$ \\
\hline 5.556 & 0.508 & 3.22 \\
16.667 & 0.643 & 4.40 \\
27.778 & 0.772 & 5.91 \\
& & \\
38.889 & 0.854 & 7.14 \\
50.000 & 0.858 & 7.21 \\
61.111 & 0.903 & 7.99 \\
72.222 & 0.990 & 9.77 \\
83.333 & 1.120 & 13.1 \\
94.444 & 1.246 & 17.6 \\
\hline
\end{tabular}


Table A.4. Log Model 1 - Scenerio 2 tc Regression for North Region

\begin{tabular}{lr}
\hline \multicolumn{2}{c}{ Regression Statistics } \\
\hline Multiple \\
$\mathrm{R}$ & 0.88 \\
$\mathrm{R}^{2}$ & 0.78 \\
Adj $\mathrm{R}^{2}$ & 0.71 \\
Std Error & 0.12 \\
Obs & 9 \\
\hline
\end{tabular}

\begin{tabular}{|c|c|c|c|c|c|}
\hline & $d f$ & $S S$ & $M S$ & $F$ & $\operatorname{Sig} F$ \\
\hline Regressio & & & & 10.62 & \\
\hline $\mathrm{n}$ & 2 & 0.320 & 0.160 & 0 & 0.011 \\
\hline Residual & 6 & 0.091 & 0.015 & & \\
\hline \multirow[t]{2}{*}{ Total } & 8 & 0.411 & & & \\
\hline & $\begin{array}{c}\text { Coefficient } \\
s \\
\end{array}$ & $\begin{array}{c}\text { Std } \\
\text { Error } \\
\end{array}$ & $t$ Stat & $\begin{array}{c}P- \\
\text { value }\end{array}$ & \\
\hline Intercept & -0.254 & 0.251 & $1 . \overline{-}$ & 0.351 & \\
\hline ContDA & 0.841 & 0.186 & $\begin{array}{c}4.522 \\
-\end{array}$ & 0.004 & \\
\hline UrbanLC & -0.079 & 0.044 & 1.778 & 0.126 & \\
\hline
\end{tabular}

\section{RESIDUAL OUTPUT}

\begin{tabular}{cccc}
\hline Obs & $\begin{array}{c}\text { Predicted } \\
\text { Log }(T c)\end{array}$ & $\begin{array}{c}\text { Residual } \\
\text { s }\end{array}$ & $\begin{array}{c}\text { Std } \\
\text { Resid }\end{array}$ \\
\hline 1 & 0.622 & -0.114 & - \\
2 & 0.776 & 0.082 & 0.766 \\
3 & 0.976 & 0.013 & 0.126 \\
4 & 0.731 & 0.040 & 0.380 \\
5 & 1.073 & 0.046 & 0.436 \\
& & & - \\
6 & 1.050 & -0.197 & 1.850 \\
7 & 0.586 & 0.057 & 0.539 \\
8 & & & - \\
9 & 0.973 & -0.070 & 0.660 \\
& 1.104 & 0.142 & 1.332 \\
\hline
\end{tabular}

PROBABILITY

OUTPUT

\begin{tabular}{ccc}
\hline $\begin{array}{c}\text { Percentil } \\
e\end{array}$ & $\log (\mathrm{Tc})$ & $T c$ \\
\hline & & \\
5.56 & 0.51 & 3.22 \\
16.67 & 0.64 & 4.40 \\
27.78 & 0.77 & 5.91 \\
38.89 & 0.85 & 7.14 \\
50.00 & 0.86 & 7.21 \\
& & \\
61.11 & 0.90 & 7.99 \\
72.22 & 0.99 & 9.77 \\
& & \\
83.33 & 1.12 & 13.1 \\
94.44 & 1.25 & 17.6 \\
\hline
\end{tabular}


Table A.5. Log Model 1 - Scenerio 1 R Regression for Central Region

\begin{tabular}{lr}
\hline \multicolumn{2}{c}{ Regression Statistics } \\
\hline Multiple \\
$\mathrm{R}$ & 0.93 \\
$\mathrm{R}^{2}$ & 0.86 \\
Adj $\mathrm{R}^{2}$ & 0.82 \\
Std Error & 0.14 \\
Obs & 10 \\
\hline
\end{tabular}

\begin{tabular}{|c|c|c|c|c|}
\hline & $d f$ & $S S$ & $M S$ & $F$ \\
\hline Regressio & & & & 21.93 \\
\hline $\mathrm{n}$ & 2 & 0.884 & 0.442 & 2 \\
\hline Residual & 7 & 0.141 & 0.020 & \\
\hline \multirow[t]{2}{*}{ Total } & 9 & 1.025 & & \\
\hline & $\begin{array}{c}\text { Coefficient } \\
s \\
\end{array}$ & $\begin{array}{c}\text { Standard } \\
\text { Error }\end{array}$ & $t$ Stat & $\begin{array}{c}P- \\
\text { value }\end{array}$ \\
\hline Intercept & 1.727 & 0.266 & 6.505 & 0.000 \\
\hline $\mathrm{Rf}$ & -2.722 & 0.792 & -3.437 & 0.011 \\
\hline Slope & -0.932 & 0.244 & -3.819 & 0.007 \\
\hline
\end{tabular}

\section{RESIDUAL OUTPUT}

\begin{tabular}{cccc}
\hline Obs & $\begin{array}{c}\text { Predicted } \\
\log (R)\end{array}$ & $\begin{array}{c}\text { Residual } \\
\text { S }\end{array}$ & $\begin{array}{c}\text { Std } \\
\text { Resid }\end{array}$ \\
\hline 1 & 0.645 & -0.137 & -1.092 \\
2 & 1.285 & -0.062 & -0.493 \\
3 & 1.150 & -0.054 & -0.429 \\
4 & 1.271 & -0.006 & -0.051 \\
5 & 1.072 & -0.029 & -0.231 \\
6 & 0.621 & -0.049 & -0.395 \\
7 & 0.454 & -0.122 & -0.973 \\
8 & 0.822 & 0.164 & 1.308 \\
9 & 0.773 & 0.264 & 2.109 \\
10 & 0.502 & 0.031 & 0.247 \\
\hline
\end{tabular}

PROBABILITY

OUTPUT

\begin{tabular}{ccc}
\hline $\begin{array}{c}\text { Percentil } \\
e\end{array}$ & $\log (R)$ & $\mathrm{R}$ \\
\hline 5 & 0.332 & 2.15 \\
15 & 0.508 & 3.22 \\
25 & 0.533 & 3.41 \\
35 & 0.572 & 3.73 \\
45 & 0.986 & 9.68 \\
55 & 1.037 & 10.9 \\
65 & 1.043 & 11.0 \\
75 & 1.096 & 12.4 \\
85 & 1.223 & 16.7 \\
95 & 1.265 & 18.4 \\
\hline
\end{tabular}


Table A.6. Square Root Model 1 - Scenerio 2 R Regression for Central Region

\begin{tabular}{|c|c|c|c|c|c|}
\hline \multicolumn{2}{|c|}{ Regression Statistics } & & & & \\
\hline \multicolumn{2}{|c|}{ Multiple } & & & & \\
\hline $\mathrm{R}$ & 0.83 & & & & \\
\hline $\mathrm{R}^{2}$ & 0.69 & & & & \\
\hline $\operatorname{Adj} R^{2}$ & 0.60 & & & & \\
\hline Std Error & 0.65 & & & & \\
\hline Obs & 10 & & & & \\
\hline \multicolumn{6}{|l|}{ ANOVA } \\
\hline & $d f$ & $S S$ & $M S$ & $F$ & $\operatorname{Sig} F$ \\
\hline \multicolumn{6}{|l|}{ Regressio } \\
\hline $\mathrm{n}$ & 2 & 6.477 & 3.238 & 7.629 & 0.017 \\
\hline Residual & 7 & 2.971 & 0.424 & & \\
\hline \multirow[t]{2}{*}{ Total } & 9 & 9.448 & & & \\
\hline & $\begin{array}{c}\text { Coefficient } \\
s \\
\end{array}$ & $\begin{array}{c}\text { Standard } \\
\text { Error }\end{array}$ & $t$ Stat & $\begin{array}{c}P- \\
\text { value }\end{array}$ & \\
\hline Intercept & 6.189 & 0.990 & 6.250 & 0.000 & \\
\hline Slope & -0.949 & 0.319 & -2.975 & 0.021 & \\
\hline UrbanLC & -0.048 & 0.077 & -0.631 & 0.548 & \\
\hline
\end{tabular}

RESIDUAL OUTPUT

\begin{tabular}{cccc}
\hline Obs & $\begin{array}{c}\text { Predicted } \\
\text { VR }\end{array}$ & $\begin{array}{c}\text { Residual } \\
S\end{array}$ & Std Resid \\
\hline 1 & 3.020 & -1.225 & -2.133 \\
2 & 3.409 & 0.681 & 1.185 \\
3 & 3.704 & -0.172 & -0.300 \\
4 & 4.166 & 0.123 & 0.215 \\
5 & 3.218 & 0.106 & 0.185 \\
6 & 2.124 & -0.193 & -0.335 \\
7 & 1.880 & -0.414 & -0.720 \\
& & & \\
8 & 2.288 & 0.824 & 1.434 \\
9 & 3.281 & 0.020 & 0.035 \\
10 & 1.596 & 0.250 & 0.435 \\
\hline
\end{tabular}

PROBABILITY OUTPUT

\begin{tabular}{ccc}
\hline $\begin{array}{c}\text { Percentil } \\
e\end{array}$ & $\mathrm{~V} R$ & $\mathrm{R}$ \\
\hline 5 & 1.46 & 2.15 \\
15 & 1.79 & 3.22 \\
25 & 1.84 & 3.41 \\
35 & 1.93 & 3.73 \\
45 & 3.11 & 9.68 \\
55 & 3.30 & 10.9 \\
65 & 3.32 & 11.0 \\
& & 12.4 \\
75 & 3.53 & 7 \\
& & 16.7 \\
85 & 4.09 & 3 \\
95 & 4.29 & 18.4 \\
\hline
\end{tabular}


Table A.7. Log Model $1-$ Scenerio $1 t_{c}$ Regression for Central Region

\begin{tabular}{lr}
\hline \multicolumn{2}{c}{ Regression Statistics } \\
\hline Multiple \\
$\mathrm{R}$ & 0.92 \\
$\mathrm{R}^{2}$ & 0.84 \\
Adj $\mathrm{R}^{2}$ & 0.76 \\
Std Error & 0.12 \\
Obs & 10 \\
\hline
\end{tabular}

\begin{tabular}{|c|c|c|c|c|}
\hline & $d f$ & $S S$ & $M S$ & $F$ \\
\hline Regressio & & & & 10.67 \\
\hline $\mathrm{n}$ & 3 & 0.489 & 0.163 & 4 \\
\hline Residual & 6 & 0.092 & 0.015 & \\
\hline Total & 9 & 0.581 & & \\
\hline & $\begin{array}{c}\text { Coefficient } \\
s \\
\end{array}$ & $\begin{array}{l}\text { Standar } \\
d \text { Error }\end{array}$ & $t$ Stat & $\begin{array}{c}P- \\
\text { value }\end{array}$ \\
\hline Intercept & -1.944 & 0.685 & -2.840 & 0.030 \\
\hline Ls & -0.927 & 0.192 & -4.831 & 0.003 \\
\hline $\mathrm{H}$ & 0.956 & 0.304 & 3.139 & 0.020 \\
\hline UrbanLC & -0.125 & 0.045 & -2.775 & 0.032 \\
\hline
\end{tabular}

\section{RESIDUAL OUTPUT}

\begin{tabular}{cccc}
\hline Obs & $\begin{array}{c}\text { Predicted } \\
\text { Log }(T c)\end{array}$ & $\begin{array}{c}\text { Residual } \\
s\end{array}$ & $\begin{array}{c}\text { Std } \\
\text { Resid }\end{array}$ \\
\hline 1 & 0.703 & -0.180 & -1.788 \\
2 & 1.263 & -0.010 & -0.097 \\
3 & 0.740 & 0.020 & 0.200 \\
4 & 1.003 & -0.002 & -0.019 \\
5 & 0.739 & 0.025 & 0.248 \\
6 & 0.853 & -0.082 & -0.812 \\
7 & 0.490 & 0.062 & 0.612 \\
8 & 0.719 & -0.060 & -0.593 \\
9 & 0.871 & 0.209 & 2.067 \\
10 & 0.470 & 0.018 & 0.183 \\
\hline
\end{tabular}

PROBABILITY

OUTPUT

\begin{tabular}{ccc}
\hline $\begin{array}{c}\text { Percentil } \\
e\end{array}$ & $\log (T c)$ & $T c$ \\
\hline 5 & 0.489 & 3.08 \\
15 & 0.522 & 3.33 \\
25 & 0.551 & 3.56 \\
35 & 0.659 & 4.56 \\
45 & 0.760 & 5.76 \\
55 & 0.764 & 5.81 \\
65 & 0.771 & 5.9 \\
75 & 1.001 & 10.0 \\
85 & 1.080 & 12.0 \\
95 & 1.253 & 17.9 \\
\hline
\end{tabular}


Table A.8. Log Model 1 - Scenerio $2 t_{c}$ Regression for Central Region

\begin{tabular}{|c|c|c|c|c|c|}
\hline \multicolumn{2}{|c|}{ Regression Statistics } & & & & \\
\hline Multiple & & & & & \\
\hline $\mathrm{R}$ & 0.64 & & & & \\
\hline $\mathrm{R}^{2}$ & 0.41 & & & & \\
\hline $\operatorname{Adj} R^{2}$ & 0.34 & & & & \\
\hline Std Error & 0.21 & & & & \\
\hline Obs & 10 & & & & \\
\hline \multicolumn{6}{|l|}{ ANOVA } \\
\hline & $d f$ & SS & $M S$ & $F$ & $\operatorname{Sig} F$ \\
\hline & & & & 5.56 & \\
\hline Regression & 1 & 0.238 & 0.238 & 3 & 0.046 \\
\hline Residual & 8 & 0.343 & 0.043 & & \\
\hline \multirow[t]{2}{*}{ Total } & 9 & 0.581 & & & \\
\hline & $\begin{array}{c}\text { Coefficient } \\
s \\
\end{array}$ & $\begin{array}{c}\text { Standard } \\
\text { Error }\end{array}$ & $t$ Stat & $\begin{array}{c}P- \\
\text { value }\end{array}$ & \\
\hline Intercept & 1.574 & 0.341 & 4.617 & $\begin{array}{c}0.00 \\
2 \\
0.04\end{array}$ & \\
\hline Slope & -0.769 & 0.326 & -2.359 & 6 & \\
\hline
\end{tabular}

RESIDUAL OUTPUT

\begin{tabular}{cccc}
\hline Obs & $\begin{array}{c}\text { Predicted } \\
\text { Log }(T c)\end{array}$ & $\begin{array}{c}\text { Residual } \\
\text { s }\end{array}$ & $\begin{array}{c}\text { Std } \\
\text { Resid }\end{array}$ \\
\hline 1 & 0.776 & -0.254 & -1.301 \\
2 & 0.861 & 0.392 & 2.011 \\
3 & 0.950 & -0.190 & -0.972 \\
4 & 1.083 & -0.082 & -0.422 \\
5 & 0.823 & -0.059 & -0.301 \\
6 & 0.663 & 0.108 & 0.553 \\
7 & 0.636 & -0.084 & -0.432 \\
8 & 0.688 & -0.029 & -0.148 \\
9 & 0.841 & 0.239 & 1.222 \\
10 & 0.530 & -0.041 & -0.211 \\
\hline
\end{tabular}

PROBABILITY

OUTPUT

\begin{tabular}{ccc}
\hline Percentile & $\log (T c)$ & $T c$ \\
\hline 5 & 0.489 & 3.08 \\
15 & 0.522 & 3.33 \\
25 & 0.551 & 3.56 \\
35 & 0.659 & 4.56 \\
45 & 0.760 & 5.76 \\
55 & 0.764 & 5.81 \\
65 & 0.771 & 5.9 \\
75 & 1.001 & 10.0 \\
85 & 1.080 & 12.0 \\
95 & 1.253 & 17.9 \\
\hline
\end{tabular}


Table A.9. Log Model 1 - Scenario 1 R Regression for South Region

\begin{tabular}{|c|c|c|c|c|c|c|c|}
\hline \multicolumn{2}{|c|}{ Regression Statistics } & & & & & & \\
\hline \multicolumn{2}{|c|}{ Multiple } & & & & & & \\
\hline $\mathrm{R}$ & 0.94 & & & & & & \\
\hline $\mathrm{R}^{2}$ & 0.88 & & & & & & \\
\hline Adj $R^{2}$ & 0.82 & & & & & & \\
\hline Std Error & 0.05 & & & & & & \\
\hline Obs & 10 & & & & & & \\
\hline \multicolumn{8}{|l|}{ ANOVA } \\
\hline & $d f$ & $S S$ & $M S$ & $F$ & $\operatorname{Sig} F$ & & \\
\hline & & & & 14.94 & & & \\
\hline Regression & 3 & 0.095 & 0.032 & 1 & 0.003 & & \\
\hline Residual & 6 & 0.013 & 0.002 & & & & \\
\hline \multirow[t]{2}{*}{ Total } & 9 & 0.108 & & & & & \\
\hline & Coefs & $\begin{array}{l}\text { Stand } \\
\text { Error }\end{array}$ & $t$ Stat & $\begin{array}{c}P- \\
\text { value }\end{array}$ & & & \\
\hline Intercept & 2.012 & 0.612 & 3.287 & 0.017 & & & \\
\hline Lca & 1.450 & 0.235 & 6.180 & 0.001 & & & \\
\hline $\mathrm{C}$ & -2.361 & 0.370 & -6.373 & 0.001 & & & \\
\hline $\mathrm{Rf}$ & 1.215 & 0.242 & 5.015 & 0.002 & & & \\
\hline \multicolumn{2}{|l|}{$\begin{array}{l}\text { RESIDUAL } \\
\text { OUTPUT }\end{array}$} & & & & $\begin{array}{l}\text { PROBABILITY } \\
\text { OUTPUT }\end{array}$ & & \\
\hline Obs & $\begin{array}{c}\text { Pred } \\
\log (R)\end{array}$ & Resid & $\begin{array}{c}\text { Std } \\
\text { Resid }\end{array}$ & & Percentile & $\begin{array}{c}\log ( \\
R\end{array}$ & $R$ \\
\hline 1 & 0.399 & 0.019 & 0.50 & & 5 & 0.320 & 2.0 \\
\hline 2 & 0.435 & -0.050 & -1.32 & & 15 & 0.386 & 2.4 \\
\hline 3 & 0.438 & 0.059 & 1.57 & & 25 & 0.398 & 2.5 \\
\hline 4 & 0.594 & 0.035 & 0.93 & & 35 & 0.418 & 2.6 \\
\hline 5 & 0.522 & 0.003 & 0.08 & & 45 & 0.497 & $\begin{array}{l}3.1 \\
3.3\end{array}$ \\
\hline 6 & 0.556 & -0.035 & -0.92 & & 55 & 0.521 & $\begin{array}{c}2 \\
3.3\end{array}$ \\
\hline 7 & 0.634 & 0.030 & 0.78 & & 65 & 0.525 & $\begin{array}{c}5 \\
3.4\end{array}$ \\
\hline 8 & 0.595 & -0.052 & -1.385 & & 75 & 0.543 & $\begin{array}{c}9 \\
4.2\end{array}$ \\
\hline 9 & 0.338 & -0.017 & -0.462 & & 85 & 0.629 & $\begin{array}{c}6 \\
4.6\end{array}$ \\
\hline 10 & 0.390 & 0.008 & 0.214 & & 95 & 0.664 & 1 \\
\hline
\end{tabular}


Table A.10. Log Model 1 - Scenario $1 t_{c}$ Regression for South Region

\begin{tabular}{lr}
\hline \multicolumn{2}{c}{ Regression Statistics } \\
\hline Multiple \\
$\mathrm{R}$ & 0.98 \\
$\mathrm{R}^{2}$ & 0.95 \\
Adj R $^{2}$ & 0.91 \\
Std Error & 0.05 \\
Obs & 10 \\
\hline
\end{tabular}

\begin{tabular}{|c|c|c|c|c|c|}
\hline & $d f$ & $S S$ & $M S$ & $F$ & $\operatorname{Sig} F$ \\
\hline Regressio & & & & 25.19 & \\
\hline $\mathrm{n}$ & 4 & 0.282 & 0.071 & 8 & 0.002 \\
\hline Residual & 5 & 0.014 & 0.003 & & \\
\hline \multirow[t]{2}{*}{ Total } & 9 & 0.296 & & & \\
\hline & $\begin{array}{c}\text { Coefficient } \\
s\end{array}$ & $\begin{array}{l}\text { Standar } \\
d \text { Error }\end{array}$ & $t$ Stat & $\begin{array}{c}P- \\
\text { value }\end{array}$ & \\
\hline Intercept & -3.283 & 1.437 & -2.284 & 0.071 & \\
\hline UrbanLC & 0.266 & 0.028 & 9.381 & 0.000 & \\
\hline $\mathrm{CN}$ & 2.693 & 0.673 & 4.000 & 0.010 & \\
\hline $\mathrm{Rf}$ & 1.696 & 0.322 & 5.274 & 0.003 & \\
\hline $\mathrm{H}$ & -0.568 & 0.200 & -2.841 & 0.036 & \\
\hline
\end{tabular}

\section{RESIDUAL OUTPUT}

\begin{tabular}{cccc}
\hline Obs & $\begin{array}{c}\text { Predicted } \\
\log (T c)\end{array}$ & $\begin{array}{c}\text { Residual } \\
\text { S }\end{array}$ & $\begin{array}{c}\text { Std } \\
\text { Resid }\end{array}$ \\
\hline 1 & 0.677 & 0.037 & 0.948 \\
2 & 0.749 & 0.051 & 1.290 \\
3 & 0.421 & 0.041 & 1.042 \\
4 & 0.765 & -0.002 & -0.060 \\
5 & 0.696 & -0.045 & -1.149 \\
6 & 0.392 & 0.031 & 0.784 \\
7 & 0.456 & -0.025 & -0.634 \\
8 & 0.586 & -0.030 & -0.748 \\
9 & 0.224 & 0.004 & 0.090 \\
10 & 0.513 & -0.062 & -1.563 \\
\hline
\end{tabular}

PROBABILITY OUTPUT

\begin{tabular}{ccc}
\hline $\begin{array}{c}\text { Percentil } \\
e\end{array}$ & $\log (T c$ & $T c$ \\
\hline 5 & 0.228 & 1.69 \\
15 & 0.423 & 2.65 \\
25 & 0.431 & 2.7 \\
35 & 0.452 & 2.83 \\
45 & 0.462 & 2.9 \\
55 & 0.556 & 3.6 \\
65 & 0.650 & 4.47 \\
75 & 0.714 & 5.18 \\
85 & 0.763 & 5.79 \\
95 & 0.800 & 6.31 \\
\hline
\end{tabular}


Table A.11. Log Model 1 - Scenario 2 R Regression for South Region

\begin{tabular}{|c|c|c|c|c|c|c|c|}
\hline \multicolumn{2}{|c|}{ Regression Statistics } & & & & & & \\
\hline \multicolumn{2}{|c|}{ Multiple } & & & & & & \\
\hline $\mathrm{R}$ & 0.83 & & & & & & \\
\hline $\mathrm{R}^{2}$ & 0.69 & & & & & & \\
\hline Adj $R^{2}$ & 0.60 & & & & & & \\
\hline Std Error & 0.11 & & & & & & \\
\hline Obs & 10 & & & & & & \\
\hline \multicolumn{8}{|l|}{ ANOVA } \\
\hline & $d f$ & $S S$ & $M S$ & $F$ & $\operatorname{Sig} F$ & & \\
\hline Regressio & & & & 7.75 & & & \\
\hline $\mathrm{n}$ & 2 & 0.204 & 0.102 & 1 & 0.017 & & \\
\hline Residual & 7 & 0.092 & 0.013 & & & & \\
\hline \multirow[t]{2}{*}{ Total } & 9 & 0.296 & & & & & \\
\hline & Coeff & $\begin{array}{l}\text { Stand } \\
\text { Error }\end{array}$ & $t$ Stat & $\begin{array}{c}P- \\
\text { value }\end{array}$ & & & \\
\hline Intercept & -3.503 & 2.291 & -1.529 & $\begin{array}{c}0.17 \\
0 \\
0.00\end{array}$ & & & \\
\hline UrbanLC & 0.179 & 0.049 & 3.677 & $\begin{array}{c}8 \\
0.11\end{array}$ & & & \\
\hline $\mathrm{CN}$ & 2.205 & 1.231 & 1.791 & 6 & & & \\
\hline $\begin{array}{l}\text { RESI } \\
\text { OUTPUT }\end{array}$ & & & & \multicolumn{4}{|c|}{$\begin{array}{l}\text { PROBABILITY } \\
\text { OUTPUT }\end{array}$} \\
\hline Obs & $\begin{array}{c}\text { Predicte } \\
d \\
\log (T c)\end{array}$ & Residuals & $\begin{array}{c}\text { Std } \\
\text { Resid }\end{array}$ & & $\begin{array}{c}\text { Percentil } \\
e \\
\end{array}$ & $\log (T c)$ & $T c$ \\
\hline 1 & 0.738 & -0.024 & -0.238 & & 5 & 0.228 & 1.69 \\
\hline 2 & 0.701 & 0.099 & 0.982 & & 15 & 0.423 & 2.65 \\
\hline 3 & 0.413 & 0.049 & 0.488 & & 25 & 0.431 & 2.70 \\
\hline 4 & 0.569 & 0.194 & 1.915 & & 35 & 0.452 & 2.83 \\
\hline 5 & 0.776 & -0.126 & -1.245 & & 45 & 0.462 & 2.90 \\
\hline 6 & 0.481 & -0.058 & -0.574 & & 55 & 0.556 & 3.60 \\
\hline 7 & 0.440 & -0.009 & -0.085 & & 65 & 0.650 & 4.47 \\
\hline 8 & 0.492 & 0.064 & 0.637 & & 75 & 0.714 & 5.18 \\
\hline 9 & 0.315 & -0.087 & -0.861 & & 85 & 0.763 & 5.79 \\
\hline 10 & 0.555 & -0.103 & -1.020 & & 95 & 0.800 & 6.31 \\
\hline
\end{tabular}


Table A.12. Log Model 1 - Scenario 2 R Regression for State

\begin{tabular}{lr}
\multicolumn{2}{l}{$\begin{array}{l}\text { SUMMARY } \\
\text { OUTPUT }\end{array}$} \\
\hline \multicolumn{2}{c}{ Regression Statistics } \\
\hline Multiple R & 0.84 \\
$\mathrm{R}^{2}$ & 0.70 \\
Adj R $^{2}$ & 0.68 \\
Std Error & 0.21 \\
Obs & 29 \\
\hline
\end{tabular}

ANOVA

\begin{tabular}{lccccc}
\hline & $d f$ & $S S$ & $M S$ & $F$ & Sig $F$ \\
\hline Regression & 2 & 2.725 & 1.363 & 30.452 & 0.00000 \\
Residual & 26 & 1.163 & 0.045 & & \\
Total & 28 & 3.889 & & & \\
\hline
\end{tabular}

\begin{tabular}{|c|c|c|c|c|}
\hline & & Standara & & $P_{-}$ \\
\hline & Coefficients & Error & $t$ Stat & value \\
\hline Intercept & 1.456 & 0.270 & $\begin{array}{c}5.401 \\
-\end{array}$ & 0.0000 \\
\hline Slope & -0.773 & 0.178 & 4.348 & 0.0002 \\
\hline Sinks & 0.382 & 0.153 & 2.490 & 0.0195 \\
\hline
\end{tabular}


Table A.12. Log Model 1 - Scenario 2 Regression for State

\begin{tabular}{|c|c|c|c|}
\hline Obs & $\begin{array}{c}\text { Pred } \\
\log (R)\end{array}$ & Resid & $\begin{array}{c}\text { Std } \\
\text { Resid }\end{array}$ \\
\hline 1 & 1.237 & 0.089 & 0.437 \\
\hline 2 & 0.742 & 0.262 & 1.284 \\
\hline 3 & 1.108 & 0.219 & 1.073 \\
\hline 4 & 1.042 & 0.026 & 0.127 \\
\hline 5 & 1.416 & -0.056 & -0.275 \\
\hline 6 & 1.088 & 0.238 & 1.166 \\
\hline 7 & 0.855 & -0.146 & -0.716 \\
\hline 8 & 1.070 & 0.225 & 1.102 \\
\hline 9 & 1.520 & -0.184 & -0.903 \\
\hline 10 & 0.870 & -0.363 & -1.779 \\
\hline 11 & 0.893 & 0.331 & 1.623 \\
\hline 12 & 1.165 & -0.069 & -0.340 \\
\hline 13 & 1.089 & 0.176 & 0.862 \\
\hline 14 & 0.983 & 0.060 & 0.296 \\
\hline 15 & 0.731 & -0.159 & -0.781 \\
\hline 16 & 0.782 & -0.449 & -2.203 \\
\hline 17 & 0.781 & 0.205 & 1.004 \\
\hline 18 & 0.951 & 0.087 & 0.426 \\
\hline 19 & 0.459 & 0.074 & 0.364 \\
\hline 20 & 0.653 & -0.234 & -1.149 \\
\hline 21 & 0.514 & -0.128 & -0.630 \\
\hline 22 & 0.410 & 0.087 & 0.427 \\
\hline 23 & 0.851 & -0.222 & -1.087 \\
\hline 24 & 0.753 & -0.228 & -1.120 \\
\hline 25 & 0.489 & 0.032 & 0.157 \\
\hline 26 & 0.600 & 0.064 & 0.315 \\
\hline 27 & 0.257 & 0.285 & 1.400 \\
\hline 28 & 0.330 & -0.010 & -0.048 \\
\hline 29 & 0.608 & -0.210 & -1.032 \\
\hline
\end{tabular}

\begin{tabular}{|c|c|c|}
\hline Percentile & $\log (R)$ & $R$ \\
\hline 1.724 & 0.320 & 2.09 \\
\hline 5.172 & 0.332 & 2.15 \\
\hline 8.621 & 0.386 & 2.43 \\
\hline 12.069 & 0.398 & 2.5 \\
\hline 15.517 & 0.418 & 2.62 \\
\hline 18.966 & 0.497 & 3.14 \\
\hline 22.414 & 0.508 & 3.22 \\
\hline 25.862 & 0.521 & 3.32 \\
\hline 29.310 & 0.525 & 3.35 \\
\hline 32.759 & 0.533 & 3.41 \\
\hline 36.207 & 0.543 & 3.49 \\
\hline 39.655 & 0.572 & 3.73 \\
\hline 43.103 & 0.629 & 4.26 \\
\hline 46.552 & 0.664 & 4.61 \\
\hline 50.000 & 0.709 & 5.12 \\
\hline 53.448 & 0.986 & 9.68 \\
\hline 56.897 & 1.003 & 10.08 \\
\hline 60.345 & 1.037 & 10.9 \\
\hline 63.793 & 1.043 & 11.05 \\
\hline 67.241 & 1.068 & 11.69 \\
\hline 70.690 & 1.096 & 12.47 \\
\hline 74.138 & 1.223 & 16.73 \\
\hline 77.586 & 1.265 & 18.4 \\
\hline 81.034 & 1.294 & 19.69 \\
\hline 84.483 & 1.326 & 21.18 \\
\hline 87.931 & 1.326 & 21.2 \\
\hline 91.379 & 1.327 & 21.23 \\
\hline 94.828 & 1.336 & 21.67 \\
\hline 98.276 & 1.360 & 22.9 \\
\hline
\end{tabular}


Table A.13. Log Model 1 - Scenario 2 tc Regression for State

\begin{tabular}{lr}
\hline \multicolumn{2}{c}{ Regression Statistics } \\
\hline Multiple R & 0.79 \\
$\mathrm{R}^{2}$ & 0.62 \\
Adj R & 0.58 \\
Std Error & 0.17 \\
Obs & 29 \\
\hline
\end{tabular}

ANOVA

\begin{tabular}{|c|c|c|c|c|}
\hline & $d f$ & $S S$ & $M S$ & $F$ \\
\hline Regression & 3 & 1.147 & 0.382 & 13.732 \\
\hline Residual & 25 & 0.696 & 0.028 & \\
\hline \multirow[t]{3}{*}{ Total } & 28 & 1.843 & & \\
\hline & & Standara & & \\
\hline & Coefficients & Error & $t$ Stat & P-value \\
\hline & & & - & \\
\hline Intercept & -2.176 & 0.859 & 2.533 & 0.018 \\
\hline $\mathrm{Lb}$ & 0.639 & 0.214 & 2.984 & 0.006 \\
\hline Ls & -0.307 & 0.092 & $3 . \overline{325}$ & 0.003 \\
\hline Water & 0.106 & 0.053 & 2.021 & 0.054 \\
\hline
\end{tabular}


Table A.13. Log Model 1 - Scenario 2 Regression for State

RESID

OUTPUT

\begin{tabular}{|c|c|c|c|}
\hline Obs & $\begin{array}{c}\text { Pred } \\
\log (T c)\end{array}$ & Resid & Std Resid \\
\hline 1 & 0.669 & -0.161 & -1.023 \\
\hline 2 & 0.738 & 0.120 & 0.762 \\
\hline 3 & 0.877 & 0.113 & 0.715 \\
\hline 4 & 0.797 & -0.025 & -0.161 \\
\hline 5 & 1.037 & 0.082 & 0.523 \\
\hline 6 & 0.801 & 0.053 & 0.337 \\
\hline 7 & 0.696 & -0.052 & -0.332 \\
\hline 8 & 0.932 & -0.029 & -0.185 \\
\hline 9 & 0.933 & 0.312 & 1.979 \\
\hline 10 & 0.532 & -0.009 & -0.058 \\
\hline 11 & 1.004 & 0.249 & 1.579 \\
\hline 12 & 0.954 & -0.193 & -1.225 \\
\hline 13 & 1.042 & -0.041 & -0.259 \\
\hline 14 & 0.779 & -0.015 & -0.093 \\
\hline 15 & 0.925 & -0.154 & -0.976 \\
\hline 16 & 0.700 & -0.149 & -0.944 \\
\hline 17 & 0.841 & -0.182 & -1.152 \\
\hline 18 & 0.829 & 0.251 & 1.594 \\
\hline 19 & 0.407 & 0.081 & 0.515 \\
\hline 20 & 0.651 & 0.064 & 0.404 \\
\hline 21 & 0.520 & 0.280 & 1.773 \\
\hline 22 & 0.420 & 0.042 & 0.267 \\
\hline 23 & 0.765 & -0.003 & -0.017 \\
\hline 24 & 0.864 & -0.213 & -1.353 \\
\hline 25 & 0.669 & -0.246 & -1.559 \\
\hline 26 & 0.575 & -0.144 & -0.910 \\
\hline 27 & 0.349 & 0.207 & 1.312 \\
\hline 28 & 0.355 & -0.127 & -0.807 \\
\hline 29 & 0.564 & -0.112 & -0.709 \\
\hline
\end{tabular}

PROBABILITY

OUTPUT

\begin{tabular}{|c|c|c|}
\hline Percentile & $\log (T c)$ & $T c$ \\
\hline 1.724 & 0.228 & 1.69 \\
\hline 5.172 & 0.423 & 2.65 \\
\hline 8.621 & 0.431 & 2.7 \\
\hline 12.069 & 0.452 & 2.83 \\
\hline 15.517 & 0.462 & 2.9 \\
\hline 18.966 & 0.489 & 3.08 \\
\hline 22.414 & 0.508 & 3.22 \\
\hline 25.862 & 0.522 & 3.33 \\
\hline 29.310 & 0.551 & 3.56 \\
\hline 32.759 & 0.556 & 3.6 \\
\hline 36.207 & 0.643 & 4.4 \\
\hline 39.655 & 0.650 & 4.47 \\
\hline 43.103 & 0.659 & 4.56 \\
\hline 46.552 & 0.714 & 5.18 \\
\hline 50.000 & 0.760 & 5.76 \\
\hline 53.448 & 0.763 & 5.79 \\
\hline 56.897 & 0.764 & 5.81 \\
\hline 60.345 & 0.771 & 5.9 \\
\hline 63.793 & 0.772 & 5.91 \\
\hline 67.241 & 0.800 & 6.31 \\
\hline 70.690 & 0.854 & 7.14 \\
\hline 74.138 & 0.858 & 7.21 \\
\hline 77.586 & 0.903 & 7.99 \\
\hline 81.034 & 0.990 & 9.77 \\
\hline 84.483 & 1.001 & 10.02 \\
\hline 87.931 & 1.080 & 12.02 \\
\hline 91.379 & 1.120 & 13.17 \\
\hline 94.828 & 1.246 & 17.6 \\
\hline 98.276 & 1.253 & 17.9 \\
\hline
\end{tabular}


Appendix B

The entries in Table B.1 are the extracted geomorphologic parameters 
Table B.1. Extracted Geomorphologic Parameters

\begin{tabular}{|c|c|c|c|c|c|c|c|c|c|c|}
\hline Station Name & $\begin{array}{c}\text { Station } \\
\text { No. }\end{array}$ & Region & $\begin{array}{l}\text { Lp } \\
(\mathrm{m})\end{array}$ & $\begin{array}{l}\mathrm{Lb} \\
(\mathrm{m})\end{array}$ & $\begin{array}{l}\text { Lca } \\
(\mathrm{m})\end{array}$ & $\begin{array}{c}\text { Rff } \\
\left(\mathrm{m}^{2} / \mathrm{m}^{2}\right)\end{array}$ & $\begin{array}{l}\text { Ap } \\
\text { (m) }\end{array}$ & $\begin{array}{c}\mathrm{Rc} \\
\left(\mathrm{m}^{2} / \mathrm{m}^{2}\right) \\
\end{array}$ & $\begin{array}{c}\mathrm{Re} \\
(\mathrm{m} / \mathrm{m})\end{array}$ & $\begin{array}{c}\mathrm{Sb} \\
\left(\mathrm{m}^{2} / \mathrm{m}^{2}\right)\end{array}$ \\
\hline WEESAU CREEK & 03328430 & $\mathrm{~N}$ & 37440 & 8974 & 4483 & 0.328 & 111548101 & 0.236 & 0.646 & 1.44 \\
\hline GALENA RIVER & 04096100 & $\mathrm{~N}$ & 36420 & 9413 & 4776 & 0.300 & 105552952 & 0.252 & 0.618 & 1.39 \\
\hline FORKER CREEK & 04100252 & $\mathrm{~N}$ & 71820 & 16365 & 7971 & 0.186 & 410469889 & 0.121 & 0.486 & 3.63 \\
\hline RIMMELL BRANCH & 04100295 & $\mathrm{~N}$ & 45120 & 10790 & 4834 & 0.238 & 162005099 & 0.171 & 0.550 & 3.18 \\
\hline SOLOMON CREEK & 04100377 & $\mathrm{~N}$ & 91260 & 23155 & 13790 & 0.131 & 662752587 & 0.106 & 0.408 & 5.86 \\
\hline FISH CREEK & 04177720 & $\mathrm{~N}$ & 86580 & 10999 & 2568 & 0.796 & 596520902 & 0.162 & 1.007 & 0.73 \\
\hline SPY RUN CREEK & 04182810 & $\mathrm{~N}$ & 34620 & 7216 & 3434 & 0.681 & 95377213 & 0.372 & 0.931 & 1.26 \\
\hline COBB DITCH & 05517890 & $\mathrm{~N}$ & 59220 & 16801 & 8814 & 0.289 & 279079097 & 0.293 & 0.607 & 2.73 \\
\hline IROQUOIS RIVER & 05521000 & $\mathrm{~N}$ & 83760 & 14577 & 4654 & 0.359 & 558295131 & 0.137 & 0.676 & 0.65 \\
\hline JUDAY CREEK & 04101370 & $\mathrm{~N}$ & 61260 & 16906 & 9195 & 0.260 & 298637601 & 0.249 & 0.576 & 2.76 \\
\hline WHITEWATER RIVER & $\begin{array}{l}03274650 \\
03325311\end{array}$ & $\begin{array}{l}\mathrm{C} \\
\mathrm{C}\end{array}$ & $\begin{array}{l}37320 \\
42180\end{array}$ & $\begin{array}{c}5520 \\
14125\end{array}$ & $\begin{array}{l}4203 \\
4514\end{array}$ & $\begin{array}{l}0.967 \\
0.125\end{array}$ & $\begin{array}{l}110834195 \\
141580569\end{array}$ & $\begin{array}{l}0.266 \\
0.177\end{array}$ & $\begin{array}{l}1.110 \\
0.400\end{array}$ & $\begin{array}{l}0.62 \\
4.24\end{array}$ \\
\hline BIG LICK CREEK & 03326070 & $\mathrm{C}$ & 72120 & 16996 & 7684 & 0.246 & 413906207 & 0.172 & 0.560 & 3.46 \\
\hline KOKOMO CREEK & 03333600 & $\mathrm{C}$ & 57960 & 13021 & 5932 & 0.385 & 267329728 & 0.244 & 0.700 & 0.66 \\
\hline BUCK CREEK & 03347500 & $\mathrm{C}$ & 81540 & 16305 & 8135 & 0.332 & 529092880 & 0.167 & 0.650 & 1.85 \\
\hline CROOKED CREEK & 03351310 & $\mathrm{C}$ & 56520 & 15897 & 8410 & 0.181 & 254211275 & 0.180 & 0.480 & 4.11 \\
\hline PLEASANT RUN & 03353120 & $\mathrm{C}$ & 29340 & 8451 & 3916 & 0.280 & 68503178 & 0.292 & 0.597 & 2.42 \\
\hline LITTLE BUCK CREEK & 03353637 & $\mathrm{C}$ & 65280 & 16573 & 8535 & 0.190 & 339117963 & 0.153 & 0.491 & 3.60 \\
\hline WEST FRK LICK CRK & 03353700 & $\mathrm{C}$ & 57900 & 14867 & 7123 & 0.336 & 266776537 & 0.278 & 0.654 & 2.41 \\
\hline PLUM CREEK & 03357350 & $\mathrm{C}$ & 19140 & 5780 & 2716 & 0.232 & 29152404 & 0.266 & 0.543 & 2.57 \\
\hline LITTLE INDIAN CRK & 03302300 & $\mathrm{~S}$ & 54960 & 15505 & 6664 & 0.179 & 240372041 & 0.179 & 0.478 & 3.24 \\
\hline $\begin{array}{l}\text { WEST FORK BLUE RIV } \\
\text { CROOKED CREEK }\end{array}$ & $\begin{array}{l}03302680 \\
03303400\end{array}$ & $\begin{array}{l}\mathrm{S} \\
\mathrm{S}\end{array}$ & $\begin{array}{l}44280 \\
28560\end{array}$ & $\begin{array}{c}12159 \\
6593\end{array}$ & $\begin{array}{l}6584 \\
3283\end{array}$ & $\begin{array}{l}0.329 \\
0.472\end{array}$ & $\begin{array}{c}156029144 \\
64909298\end{array}$ & $\begin{array}{l}0.311 \\
0.316\end{array}$ & $\begin{array}{l}0.647 \\
0.775\end{array}$ & $\begin{array}{l}2.55 \\
1.77\end{array}$ \\
\hline BUSSERON CREEK & 03342100 & $\mathrm{~S}$ & 42060 & 11146 & 5626 & 0.335 & 140776136 & 0.296 & 0.653 & 2.22 \\
\hline HARBERTS CREEK & 03366200 & $\mathrm{~S}$ & 44460 & 13021 & 6672 & 0.134 & 157300252 & 0.144 & 0.413 & 5.86 \\
\hline BRUSH CREEK & 03368000 & $\mathrm{~S}$ & 45120 & 13154 & 5695 & 0.171 & 162005099 & 0.183 & 0.467 & 4.87 \\
\hline BACK CREEK & 03371520 & $\mathrm{~S}$ & 54240 & 14200 & 7462 & 0.310 & 234115337 & 0.267 & 0.628 & 2.07 \\
\hline STEPHENS CREEK & 03372300 & $\mathrm{~S}$ & 34200 & 8979 & 3786 & 0.349 & 93077072 & 0.302 & 0.666 & 2.02 \\
\hline PATOKA RIVER & 03374455 & $\mathrm{~S}$ & 34800 & 8586 & 4028 & 0.442 & 96371583 & 0.338 & 0.750 & 1.49 \\
\hline HALL CREEK & 03375800 & $\mathrm{~S}$ & 50160 & 13516 & 6803 & 0.308 & 200219125 & 0.281 & 0.626 & 2.07 \\
\hline
\end{tabular}


Table B.1 Extracted Geomorphologic Parameters (Continued)

\begin{tabular}{|c|c|c|c|c|c|c|c|c|c|c|}
\hline Station Name & $\begin{array}{l}\text { Station } \\
\text { No. }\end{array}$ & Region & $\mathrm{Ru}$ & $\begin{array}{r}\mathrm{H} \\
(\mathrm{m}) \\
\end{array}$ & $\begin{array}{l}\mathrm{Rh} \\
(\mathrm{m})\end{array}$ & $\begin{array}{c}\mathrm{Rp} \\
(\mathrm{m} / \mathrm{m}) \\
\end{array}$ & $\begin{array}{c}\mathrm{D} \\
\left(\mathrm{m} / \mathrm{m}^{2}\right) \\
\end{array}$ & $\begin{array}{c}\mathrm{Rn} \\
\left(\mathrm{m}^{2} / \mathrm{m}^{2}\right) \\
\end{array}$ & $\begin{array}{c}\mathrm{C} \\
\text { (m) } \\
\end{array}$ & $\begin{array}{l}\mathrm{Rf} \\
(\mathrm{m} / \mathrm{m}) \\
\end{array}$ \\
\hline WEESAU CREEK & 03328430 & $\mathrm{~N}$ & 1.75 & 32.71 & 0.0036 & 0.0009 & 0.0013 & 0.044 & 743.9 & 0.947 \\
\hline GALENA RIVER & 04096100 & $\mathrm{~N}$ & 1.83 & 103.03 & 0.0109 & 0.0028 & 0.0015 & 0.153 & 675.5 & 1.080 \\
\hline FORKER CREEK & 04100252 & $\mathrm{~N}$ & 2.32 & 49.53 & 0.0030 & 0.0007 & 0.0011 & 0.053 & 938.0 & 0.738 \\
\hline RIMMELL BRANCH & 04100295 & $\mathrm{~N}$ & 2.05 & 35.79 & 0.0033 & 0.0008 & 0.0014 & 0.049 & 725.5 & 0.845 \\
\hline SOLOMON CREEK & 04100377 & $\mathrm{~N}$ & 2.76 & 46.75 & 0.0020 & 0.0005 & 0.0008 & 0.040 & 1181.3 & 0.651 \\
\hline FISH CREEK & 04177720 & $\mathrm{~N}$ & 1.12 & 56.32 & 0.0051 & 0.0007 & 0.0009 & 0.052 & 1083.3 & 1.027 \\
\hline SPY RUN CREEK & 04182810 & $\mathrm{~N}$ & 1.21 & 37.51 & 0.0052 & 0.0011 & 0.0013 & 0.050 & 756.9 & 1.353 \\
\hline COBB DITCH & 05517890 & $\mathrm{~N}$ & 1.86 & 45.68 & 0.0027 & 0.0008 & 0.0008 & 0.039 & 1180.7 & 1.169 \\
\hline IROQUOIS RIVER & 05521000 & $\mathrm{~N}$ & 1.67 & 22.77 & 0.0016 & 0.0003 & 0.0008 & 0.019 & 1192.2 & 0.764 \\
\hline JUDAY CREEK & 04101370 & $\mathrm{~N}$ & 1.96 & 54.04 & 0.0032 & 0.0009 & 0.0009 & 0.047 & 1139.2 & 1.066 \\
\hline WHITEWATER RIVER & 03274650 & $\mathrm{C}$ & 1.02 & 43.68 & 0.0079 & 0.0012 & 0.0014 & 0.061 & 715.7 & 1.103 \\
\hline LITTLE MISS RIVER & 03325311 & $\mathrm{C}$ & 2.82 & 30.50 & 0.0022 & 0.0007 & 0.0012 & 0.036 & 847.8 & 0.699 \\
\hline BIG LICK CREEK & 03326070 & $\mathrm{C}$ & 2.02 & 30.52 & 0.0018 & 0.0004 & 0.0009 & 0.027 & 1147.0 & 0.860 \\
\hline KOKOMO CREEK & 03333600 & $\mathrm{C}$ & 1.61 & 19.88 & 0.0015 & 0.0003 & 0.0008 & 0.016 & 1265.2 & 0.889 \\
\hline BUCK CREEK & 03347500 & $\mathrm{C}$ & 1.74 & 61.88 & 0.0038 & 0.0008 & 0.0007 & 0.046 & 1341.2 & 0.806 \\
\hline CROOKED CREEK & 03351310 & $\mathrm{C}$ & 2.35 & 59.30 & 0.0037 & 0.0010 & 0.0012 & 0.073 & 809.3 & 1.002 \\
\hline PLEASANT RUN & 03353120 & $\mathrm{C}$ & 1.89 & 27.77 & 0.0033 & 0.0009 & 0.0016 & 0.046 & 607.8 & 1.122 \\
\hline LITTLE BUCK CREEK & 03353637 & $\mathrm{C}$ & 2.30 & 69.43 & 0.0042 & 0.0011 & 0.0011 & 0.076 & 919.6 & 0.867 \\
\hline WEST FRK LICK CRK & 03353700 & $\mathrm{C}$ & 1.73 & 63.33 & 0.0043 & 0.0011 & 0.0008 & 0.052 & 1212.8 & 1.057 \\
\hline PLUM CREEK & 03357350 & $\mathrm{C}$ & 2.08 & 36.80 & 0.0064 & 0.0019 & 0.0024 & 0.088 & 418.9 & 0.967 \\
\hline $\begin{array}{l}\text { LITTLE INDIAN CREEK } \\
\text { WEST FORK BLUE }\end{array}$ & 03302300 & $\mathrm{~S}$ & 2.36 & 89.38 & 0.0058 & 0.0016 & 0.0010 & 0.093 & 966.2 & 0.811 \\
\hline RIVER & 03302680 & $\mathrm{~S}$ & 1.74 & 105.39 & 0.0087 & 0.0024 & 0.0009 & 0.100 & 1053.1 & 1.042 \\
\hline CROOKED CREEK & 03303400 & $\mathrm{~S}$ & 1.46 & 73.25 & 0.0111 & 0.0026 & 0.0015 & 0.107 & 686.7 & 1.047 \\
\hline BUSSERON CREEK & 03342100 & $\mathrm{~S}$ & 1.73 & 58.55 & 0.0053 & 0.0014 & 0.0012 & 0.068 & 861.5 & 1.150 \\
\hline HARBERTS CREEK & 03366200 & $\mathrm{~S}$ & 2.73 & 53.14 & 0.0041 & 0.0012 & 0.0013 & 0.069 & 772.4 & 0.662 \\
\hline BRUSH CREEK & 03368000 & $\mathrm{~S}$ & 2.42 & 64.67 & 0.0049 & 0.0014 & 0.0013 & 0.084 & 771.7 & 0.851 \\
\hline BACK CREEK & 03371520 & $\mathrm{~S}$ & 1.80 & 102.50 & 0.0072 & 0.0019 & 0.0010 & 0.103 & 991.3 & 1.162 \\
\hline STEPHENS CREEK & 03372300 & $\mathrm{~S}$ & 1.69 & 105.48 & 0.0117 & 0.0031 & 0.0015 & 0.153 & 688.2 & 1.194 \\
\hline PATOKA RIVER & 03374455 & $\mathrm{~S}$ & 1.50 & 109.34 & 0.0127 & 0.0031 & 0.0011 & 0.126 & 870.9 & 1.076 \\
\hline HALL CREEK & 03375800 & $\mathrm{~S}$ & 1.80 & 100.40 & 0.0074 & 0.0020 & 0.0009 & 0.091 & 1107.0 & 1.013 \\
\hline
\end{tabular}


Table B.1. Extracted Geomorphologic Parameters (Continued)

\begin{tabular}{|c|c|c|c|c|c|c|c|c|c|c|}
\hline Station Name & $\begin{array}{c}\text { Station } \\
\text { No. }\end{array}$ & Region & $\begin{array}{c}\mathrm{Cf} \\
\left(\# \text { stream } / \mathrm{km}^{2}\right) \\
\end{array}$ & $\begin{array}{c}\text { Ls } \\
(\mathrm{m} / \mathrm{m}) \\
\end{array}$ & $\begin{array}{c}\text { Cs } \\
(\mathrm{m} / \mathrm{m}) \\
\end{array}$ & HKR & Gray & Murphey & $\begin{array}{l}\text { Area } \\
\left(\mathrm{mi}^{2}\right) \\
\end{array}$ & $\begin{array}{l}\text { Slope } \\
(\mathrm{ft} / \mathrm{mi})\end{array}$ \\
\hline WEESAU CREEK & 03328430 & $\mathrm{~N}$ & 1.40 & 0.0797 & 0.0013 & 537497 & 122528 & 0.0547 & 9.3 & 6.54 \\
\hline GALENA RIVER & 04096100 & $\mathrm{~N}$ & 1.54 & 0.1451 & 0.0056 & 122647 & 63645 & 0.0521 & 17.9 & 22.00 \\
\hline FORKER CREEK & 04100252 & $\mathrm{~N}$ & 1.11 & 0.1315 & 0.0014 & 1062599 & 210546 & 0.0729 & 19.3 & 9.69 \\
\hline RIMMELL BRANCH & 04100295 & $\mathrm{~N}$ & 1.99 & 0.0892 & 0.0017 & 435886 & 116916 & 0.1149 & 11.0 & 12.10 \\
\hline SOLOMON CREEK & 04100377 & $\mathrm{~N}$ & 0.50 & 0.0501 & 0.0009 & 2703877 & 461578 & 0.0835 & 36.2 & 3.56 \\
\hline FISH CREEK & 04177720 & $\mathrm{~N}$ & 0.61 & 0.0999 & 0.0020 & 1570751 & 57148 & 0.0076 & 37.4 & 11.30 \\
\hline SPY RUN CREEK & 04182810 & $\mathrm{~N}$ & 1.33 & 0.0634 & 0.0024 & 405275 & 70007 & 0.0356 & 13.9 & 14.60 \\
\hline COBB DITCH & 05517890 & $\mathrm{~N}$ & 0.62 & 0.0651 & 0.0012 & 2283199 & 251328 & 0.0334 & 30.6 & 7.14 \\
\hline IROQUOIS RIVER & 05521000 & $\mathrm{~N}$ & 0.75 & 0.0376 & 0.0006 & 4731264 & 197203 & 0.0085 & 38.1 & 3.00 \\
\hline JUDAY CREEK & 04101370 & $\mathrm{~N}$ & 0.74 & 0.0421 & 0.0011 & 2239535 & 274632 & 0.0372 & 37.3 & 7.46 \\
\hline WHITEWATER RIVER & 03274650 & $\mathrm{C}$ & 2.00 & 0.0747 & 0.0024 & 335124 & 86660 & 0.0211 & 10.4 & 10.90 \\
\hline LITTLE MISS RIVER & 03325311 & $\mathrm{C}$ & 1.32 & 0.0156 & 0.0016 & 465812 & 114169 & 0.1697 & 9.8 & 8.47 \\
\hline BIG LICK CREEK & 03326070 & $\mathrm{C}$ & 0.77 & 0.0392 & 0.0012 & 1968810 & 219686 & 0.0487 & 29.0 & 6.48 \\
\hline KOKOMO CREEK & 03333600 & $\mathrm{C}$ & 0.57 & 0.0149 & 0.0008 & 3042327 & 214859 & 0.0102 & 25.3 & 4.35 \\
\hline BUCK CREEK & 03347500 & $\mathrm{C}$ & 0.62 & 0.0898 & 0.0035 & 917363 & 137144 & 0.0210 & 35.1 & 9.48 \\
\hline CROOKED CREEK & 03351310 & $\mathrm{C}$ & 1.03 & 0.0379 & 0.0032 & 413484 & 149795 & 0.0897 & 17.9 & 15.30 \\
\hline PLEASANT RUN & 03353120 & $\mathrm{C}$ & 2.50 & 0.0402 & 0.0026 & 189329 & 76727 & 0.1211 & 8.2 & 16.60 \\
\hline LITTLE BUCK CREEK & 03353637 & $\mathrm{C}$ & 0.94 & 0.0636 & 0.0027 & 584256 & 164202 & 0.0692 & 17.1 & 14.20 \\
\hline WEST FORK LICK CRK & 03353700 & $\mathrm{C}$ & 0.71 & 0.0612 & 0.0019 & 1363031 & 163532 & 0.0325 & 28.9 & 8.97 \\
\hline PLUM CREEK & 03357350 & $\mathrm{C}$ & 6.58 & 0.0967 & 0.0049 & 32102 & 38636 & 0.3313 & 3.0 & 22.80 \\
\hline $\begin{array}{l}\text { LITTLE INDIAN CREEK } \\
\text { WEST FORK BLUE }\end{array}$ & 03302300 & $\mathrm{~S}$ & 1.60 & 0.2573 & 0.0040 & 331831 & 104908 & 0.0751 & 17.1 & 18.90 \\
\hline RIVER & 03302680 & $\mathrm{~S}$ & 1.15 & 0.2080 & 0.0053 & 299473 & 90741 & 0.0525 & 19.1 & 24.90 \\
\hline CROOKED CREEK & 03303400 & S & 2.48 & 0.2613 & 0.0060 & 89751 & 42403 & 0.0862 & 8.0 & 30.80 \\
\hline BUSSERON CREEK & 03342100 & $\mathrm{~S}$ & 1.25 & 0.0990 & 0.0032 & 387783 & 100183 & 0.0532 & 16.9 & 12.40 \\
\hline HARBERTS CREEK & 03366200 & $\mathrm{~S}$ & 2.07 & 0.0772 & 0.0027 & 230432 & 127468 & 0.2580 & 9.3 & 18.00 \\
\hline BRUSH CREEK & 03368000 & $\mathrm{~S}$ & 1.52 & 0.1293 & 0.0047 & 176310 & 83362 & 0.1644 & 11.3 & 25.60 \\
\hline BACK CREEK & 03371520 & $\mathrm{~S}$ & 1.04 & 0.2418 & 0.0048 & 408086 & 107458 & 0.0331 & 24.1 & 23.80 \\
\hline STEPHENS CREEK & 03372300 & $\mathrm{~S}$ & 1.74 & 0.4110 & 0.0079 & 92956 & 42513 & 0.0718 & 10.8 & 44.60 \\
\hline PATOKA RIVER & 03374455 & $\mathrm{~S}$ & 1.81 & 0.3592 & 0.0057 & 169077 & 53393 & 0.0457 & 12.6 & 26.00 \\
\hline HALL CREEK & 03375800 & $\mathrm{~S}$ & 0.98 & 0.3226 & 0.0035 & 540448 & 115631 & 0.0368 & 21.7 & 17.70 \\
\hline
\end{tabular}


B.1. Extracted Geomorphologic Parameters (Continued)

\begin{tabular}{|c|c|c|c|c|c|c|c|c|c|c|}
\hline Station Name & $\begin{array}{c}\text { Station } \\
\text { No. }\end{array}$ & Region & $\begin{array}{l}\mathrm{CDA} \\
\left(\mathrm{mi}^{2}\right) \\
\end{array}$ & $\begin{array}{c}\% \text { ULC } \\
(\%) \\
\end{array}$ & $\begin{array}{c}\text { Water } \\
(\%) \\
\end{array}$ & $\mathrm{CN}$ & $\begin{array}{c}\mathrm{MCh} \\
(\mathrm{mi})\end{array}$ & $\begin{array}{c}\text { Sinks } \\
(\%) \\
\end{array}$ & $\begin{array}{c}\mathrm{t}_{\mathrm{c}} \\
(\mathrm{hrs}) \\
\end{array}$ & $\begin{array}{c}\mathrm{R} \\
(\mathrm{hrs}) \\
\end{array}$ \\
\hline WEESAU CREEK & 03328430 & $\mathrm{~N}$ & 9.3 & 0.16 & 0.69 & 77 & 7.4 & 11.9 & 3.2 & 21.2 \\
\hline GALENA RIVER & 04096100 & $\mathrm{~N}$ & 16.6 & 0.90 & 13.00 & 62 & 8.4 & 7.02 & 7.2 & 10.1 \\
\hline $\begin{array}{l}\text { FORKER CREEK } \\
\text { RIMMELL }\end{array}$ & 04100252 & $\mathrm{~N}$ & 19.3 & 0.01 & 7.21 & 77 & 10.9 & 12.2 & 9.8 & 21.2 \\
\hline BRANCH & 04100295 & $\mathrm{~N}$ & 11.0 & 0.04 & 5.05 & 78 & 7.3 & 12.8 & 5.9 & 11.7 \\
\hline SOLOMON CREEK & 04100377 & $\mathrm{~N}$ & 36.2 & 0.62 & 1.76 & 77 & 16.9 & 10.3 & 13.2 & 22.9 \\
\hline FISH CREEK & 04177720 & $\mathrm{~N}$ & 36.1 & 1.16 & 6.74 & 84 & 9.8 & 14.7 & 7.1 & 21.2 \\
\hline SPY RUN CREEK & 04182810 & $\mathrm{~N}$ & 13.9 & 35.40 & 2.36 & 80 & 6.5 & 6.1 & 4.4 & 5.1 \\
\hline COBB DITCH & 05517890 & $\mathrm{~N}$ & 30.6 & 1.95 & 2.63 & 78 & 12.7 & 5.2 & 7.9 & 19.7 \\
\hline IROQUOIS RIVER & 05521000 & $\mathrm{~N}$ & 38.1 & 0.44 & 1.31 & 71 & 10.4 & 13.6 & 8.2 & 16.8 \\
\hline JUDAY CREEK & 04101370 & $\mathrm{~N}$ & 33.3 & 16.60 & 0.67 & 79 & 13.1 & & & \\
\hline WHITEWATER RIV & 03274650 & $\mathrm{C}$ & 10.4 & 0.52 & 0.54 & 79 & 7.3 & 3.7 & 3.3 & 3.2 \\
\hline LITTLE MISS RIV & 03325311 & $\mathrm{C}$ & 9.8 & 0.12 & 0.58 & 80 & 8.9 & 2.5 & 17.9 & 16.7 \\
\hline BIG LICK CREEK & 03326070 & $\mathrm{C}$ & 29.0 & 2.02 & 0.91 & 82 & 12.0 & 7.6 & 5.8 & 12.5 \\
\hline KOKOMO CREEK & 03333600 & $\mathrm{C}$ & 25.3 & 0.78 & 1.87 & 79 & 13.7 & 2.2 & 10.0 & 18.4 \\
\hline BUCK CREEK & 03347500 & $\mathrm{C}$ & 35.1 & 0.98 & 0.29 & 78 & 12.3 & 5.5 & 5.8 & 11.1 \\
\hline CROOKED CREEK & 03351310 & $\mathrm{C}$ & 17.9 & 52.80 & 0.66 & 77 & 11.1 & 3.2 & 5.9 & 3.7 \\
\hline PLEASANT RUN & 03353120 & $\mathrm{C}$ & 8.2 & 83.00 & 0.27 & 79 & 5.4 & 5.1 & 3.6 & 2.2 \\
\hline LITTLE BUCK CRK & 03353637 & $\mathrm{C}$ & 17.1 & 44.80 & 0.37 & 76 & 12.3 & 3.7 & 4.6 & 9.7 \\
\hline WEST FRK LCK CRK & 03353700 & $\mathrm{C}$ & 28.9 & 1.77 & 0.49 & 78 & 12.4 & 4.0 & 12.0 & 10.9 \\
\hline PLUM CREEK & 03357350 & $\mathrm{C}$ & 3.0 & 1.52 & 0.06 & 78 & 4.2 & 1.4 & 3.1 & 3.4 \\
\hline LITTLE INDIAN CRK & 03302300 & $\mathrm{~S}$ & 17.1 & 7.96 & 0.51 & 71 & 10.0 & 3.0 & 5.2 & 2.6 \\
\hline WEST FRK BLU RI & 03302680 & $\mathrm{~S}$ & 19.1 & 2.30 & 0.07 & 75 & 8.9 & 2.3 & 6.3 & 2.4 \\
\hline CROOKED CREEK & 03303400 & $\mathrm{~S}$ & 8.0 & 0.08 & 0.62 & 74 & 4.3 & 1.9 & 2.9 & 3.1 \\
\hline BUSSERON CRK & 03342100 & $\mathrm{~S}$ & 16.9 & 0.31 & 2.83 & 77 & 6.4 & 4.3 & 5.8 & 4.3 \\
\hline HARBERTS CRK & 03366200 & $\mathrm{~S}$ & 9.3 & 6.06 & 4.55 & 75 & 8.4 & 5.0 & 4.5 & 3.4 \\
\hline BRUSH CREEK & 03368000 & $\mathrm{~S}$ & 11.3 & 0.12 & 0.28 & 76 & 7.8 & 2.1 & 2.7 & 3.3 \\
\hline BACK CREEK & 03371520 & $\mathrm{~S}$ & 24.1 & 0.11 & 0.14 & 73 & 9.9 & 3.5 & 2.7 & 4.6 \\
\hline STEPHENS CREEK & 03372300 & $\mathrm{~S}$ & 10.8 & 1.51 & 0.08 & 63 & 5.2 & 1.6 & 3.6 & 3.5 \\
\hline PATOKA RIVER & 03374455 & $\mathrm{~S}$ & 12.6 & 0.08 & 0.08 & 66 & 6.2 & 0.8 & 1.7 & 2.1 \\
\hline HALL CREEK & 03375800 & $\mathrm{~S}$ & 21.7 & 0.21 & 0.34 & 79 & 8.7 & 2.0 & 2.8 & 2.5 \\
\hline
\end{tabular}




\section{Appendix C}

The entries in Tables C. 1 - C.6 are the summary of the stepwise selection technique for all transform models and scenarios. 
Table C.1. Stepwise selection results for Linear Model R

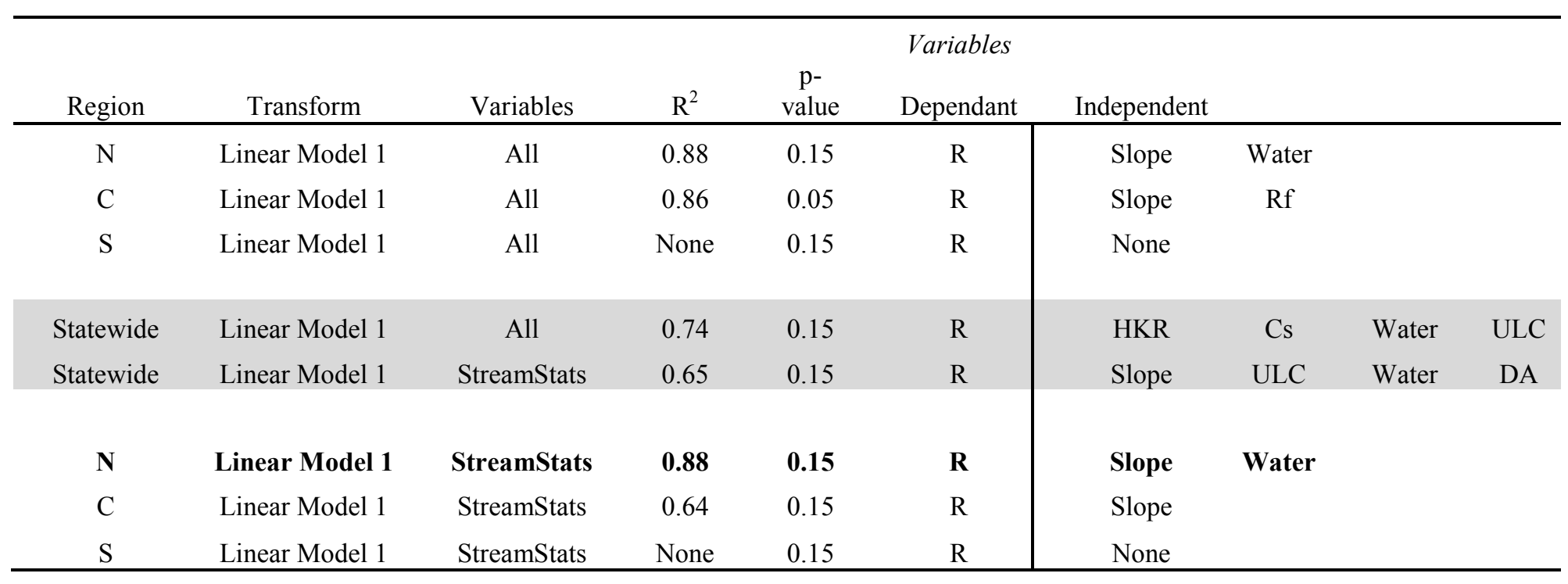


Table C.2. Stepwise selection results for Logarithmic Model R

\begin{tabular}{|c|c|c|c|c|c|c|c|c|c|}
\hline Region & Transform & Variables & $\mathrm{R}^{2}$ & $\begin{array}{c}\mathrm{p}- \\
\text { value }\end{array}$ & $\begin{array}{l}\text { Variables } \\
\text { Dependant }\end{array}$ & Independent & & & \\
\hline $\mathrm{N}$ & Log Model 2 & All & 0.59 & 0.05 & $\mathrm{R}$ & $\mathrm{Lp}$ & & & \\
\hline $\mathrm{C}$ & Log Model 2 & All & 0.91 & 0.05 & $\mathrm{R}$ & Slope & $\mathrm{Rf}$ & & \\
\hline S & Log Model 2 & All & None & 0.05 & $\mathrm{R}$ & None & & & \\
\hline $\mathbf{N}$ & Log Model 1 & All & 0.86 & 0.05 & $\mathbf{R}$ & ULC & Cf & & \\
\hline C & Log Model 1 & All & 0.86 & 0.05 & $\mathbf{R}$ & $\mathbf{R f}$ & Slope & & \\
\hline $\mathbf{S}$ & Log Model 1 & All & 0.88 & 0.05 & $\mathbf{R}$ & Lea & C & $\mathbf{R f}$ & \\
\hline Statewide & Log Model 1 & All & 0.79 & 0.05 & $\mathrm{R}$ & Slope & ULC & $\mathrm{Cf}$ & $\mathrm{C}$ \\
\hline Statewide & Log Model 2 & All & 0.75 & 0.05 & $\mathrm{R}$ & Slope & ULC & Water & \\
\hline Statewide & Log Model 1 & StreamStats & 0.72 & 0.05 & $\mathrm{R}$ & Slope & ULC & Water & \\
\hline Statewide & Log Model 2 & StreamStats & 0.75 & 0.05 & $\mathrm{R}$ & Slope & ULC & Water & \\
\hline $\mathrm{N}$ & Log Model 2 & StreamStats & 0.54 & 0.05 & $\mathrm{R}$ & Slope & & & \\
\hline $\mathrm{C}$ & Log Model 2 & StreamStats & 0.71 & 0.05 & $\mathrm{R}$ & Slope & & & \\
\hline $\mathrm{S}$ & Log Model 2 & StreamStats & & 0.05 & $\mathrm{R}$ & None & & & \\
\hline $\mathrm{N}$ & Log Model 1 & StreamStats & 0.47 & 0.05 & $\mathrm{R}$ & $\mathrm{MCh}$ & & & \\
\hline $\mathrm{C}$ & Log Model 1 & StreamStats & 0.63 & 0.05 & $\mathrm{R}$ & Slope & & & \\
\hline $\mathrm{S}$ & Log Model 1 & StreamStats & None & 0.05 & $\mathrm{R}$ & None & & & \\
\hline
\end{tabular}


Table C.3. Stepwise selection results for Square Root Model R

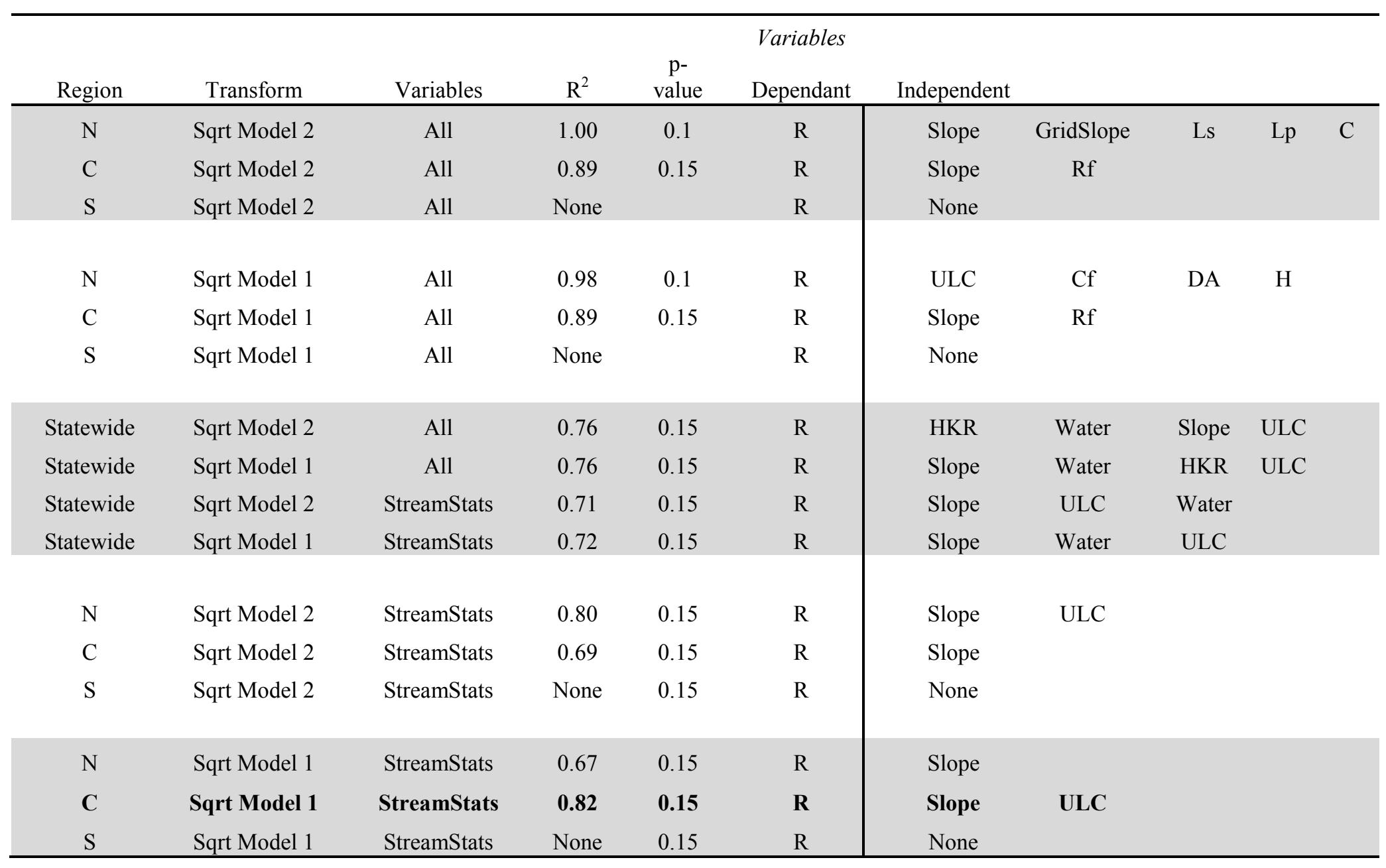


Table C.4. Stepwise selection results for Linear Model $t_{c}$

\begin{tabular}{|c|c|c|c|c|c|c|c|c|c|c|}
\hline Region & Transform & Variables & $\mathrm{R}^{2}$ & $\begin{array}{c}\mathrm{p}- \\
\text { value }\end{array}$ & $\begin{array}{l}\text { Variables } \\
\text { Dependant }\end{array}$ & Independent & & & & \\
\hline $\mathrm{N}$ & Linear Model 1 & All & 0.95 & 0.15 & $t_{c}$ & HKR & Water & M & & \\
\hline $\mathrm{C}$ & Linear Model 1 & All & 0.97 & 0.15 & $t_{c}$ & GridSlope & ULC & Water & $\mathrm{CN}$ & $\mathrm{Rn}$ \\
\hline S & Linear Model 1 & All & 0.26 & 0.15 & $t_{c}$ & ULC & & & & \\
\hline All & Linear Model 1 & All & 0.72 & 0.15 & $t_{c}$ & HKR & $\mathrm{Ru}$ & $\mathrm{Sb}$ & $\mathrm{Re}$ & Rff \\
\hline All & Linear Model 1 & StreamStats & 0.43 & 0.15 & $t_{c}$ & Slope & $\mathrm{CN}$ & & & \\
\hline $\mathrm{N}$ & Linear Model 1 & StreamStats & 0.58 & 0.15 & $t_{c}$ & CDA & & & & \\
\hline $\mathrm{C}$ & Linear Model 1 & StreamStats & 0.30 & 0.15 & $t_{c}$ & Slope & & & & \\
\hline $\mathrm{S}$ & Linear Model 1 & StreamStats & 0.26 & 0.15 & $t_{c}$ & ULC & & & & \\
\hline
\end{tabular}


Table C.5. Stepwise selection results for Log Model $t_{c}$

\begin{tabular}{|c|c|c|c|c|c|c|c|c|c|c|c|}
\hline Region & Transform & Variables & $\mathrm{R}^{2}$ & $\begin{array}{c}\mathrm{p}- \\
\text { value }\end{array}$ & $\begin{array}{l}\text { Variables } \\
\text { Dependant }\end{array}$ & Independent & & & & & \\
\hline $\mathrm{N}$ & Log Model 2 & All & 0.78 & 0.05 & $t_{c}$ & CDA & $\mathrm{Rf}$ & & & & \\
\hline $\mathrm{C}$ & Log Model 2 & All & 0.83 & 0.05 & $t_{c}$ & Ls & ULC & $\mathrm{H}$ & & & \\
\hline S & Log Model 2 & All & 0.50 & 0.05 & $t_{c}$ & ULC & & & & & \\
\hline $\mathbf{N}$ & Log Model 1 & All & 0.97 & 0.05 & $\mathbf{t}_{\mathrm{c}}$ & CDA & Cf & $\mathbf{G}$ & & & \\
\hline $\mathbf{C}$ & Log Model 1 & All & 0.84 & 0.05 & $\mathbf{t}_{\mathrm{c}}$ & Ls & $\mathbf{H}$ & ULC & & & \\
\hline $\mathbf{S}$ & Log Model 1 & All & 0.95 & 0.05 & $\mathbf{t}_{\mathrm{c}}$ & ULC & $\mathbf{C N}$ & Rf & $\mathbf{H}$ & & \\
\hline All & Log Model 1 & All & 0.62 & 0.05 & $t_{c}$ & Slope & $\mathrm{Lb}$ & Lca & & & \\
\hline All & Log Model 2 & All & 0.80 & 0.05 & $t_{c}$ & Slope & $\mathrm{Ru}$ & $\operatorname{Re}$ & Lca & CDA & $\mathrm{Rp}$ \\
\hline All & Log Model 1 & StreamStats & 0.54 & 0.05 & $t_{c}$ & Slope & Water & & & & \\
\hline All & Log Model 2 & StreamStats & 0.54 & 0.05 & $t_{c}$ & Slope & $\mathrm{CN}$ & & & & \\
\hline $\mathrm{N}$ & Log Model 2 & StreamStats & 0.84 & 0.1 & $t_{c}$ & CDA & Slope & $\mathrm{CN}$ & & & \\
\hline $\mathrm{C}$ & Log Model 2 & StreamStats & 0.30 & 0.05 & $t_{c}$ & ULC & & & & & \\
\hline $\mathrm{S}$ & Log Model 2 & StreamStats & 0.50 & 0.05 & $t_{c}$ & ULC & & & & & \\
\hline $\mathbf{N}$ & Log Model 1 & StreamStats & 0.78 & 0.05 & $\mathbf{t}_{\mathrm{c}}$ & CDA & ULC & & & & \\
\hline $\mathbf{C}$ & Log Model 1 & StreamStats & 0.41 & 0.05 & $\mathbf{t}_{\mathrm{c}}$ & Slope & & & & & \\
\hline $\mathbf{S}$ & Log Model 1 & StreamStats & 0.69 & 0.05 & $\mathbf{t}_{\mathrm{c}}$ & ULC & $\mathbf{C N}$ & & & & \\
\hline
\end{tabular}


Table C.6. Stepwise selection results for Sqrt Model $t_{c}$

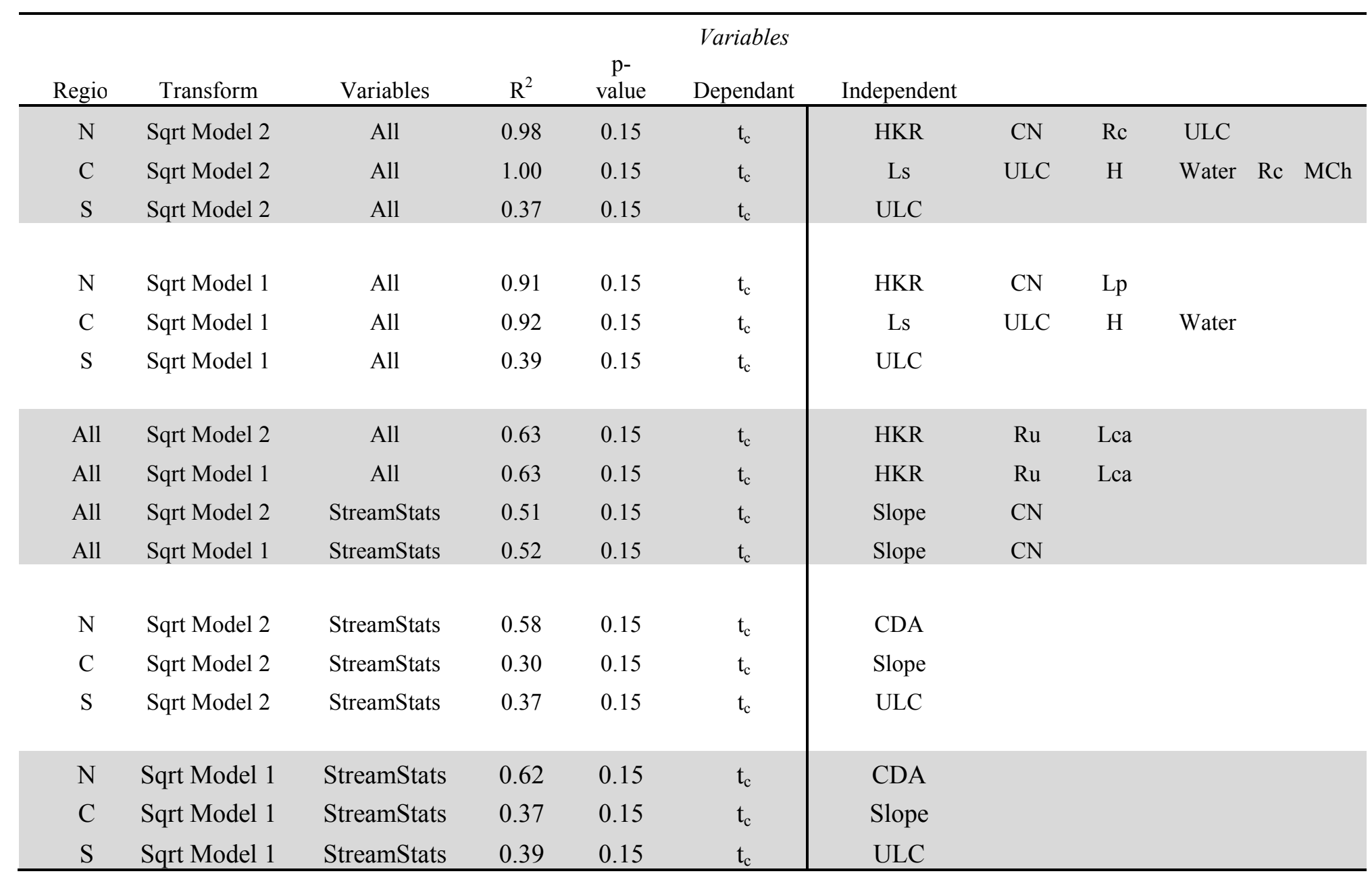




\section{Appendix D}

Correlation tables for all variables in Tables D.1. - D.3. 
Table D.1. Correlation Matrix for North Region Variables

\begin{tabular}{|c|c|c|c|c|c|c|c|c|c|c|c|c|c|c|}
\hline & $A w$ & $L p$ & $L b$ & $L c a$ & Rff & $A p$ & $R c$ & $R e$ & $S b$ & $R u$ & $T c$ & $R$ & $Q p$ & $t p$ \\
\hline$A w$ & 1.00 & & & & & & & & & & & & & \\
\hline$L p$ & 0.84 & 1.00 & & & & & & & & & & & & \\
\hline$L b$ & 0.53 & 0.74 & 1.00 & & & & & & & & & & & \\
\hline$L c a$ & 0.23 & 0.44 & 0.92 & 1.00 & & & & & & & & & & \\
\hline$R f f$ & 0.27 & -0.04 & -0.59 & -0.70 & 1.00 & & & & & & & & & \\
\hline$A p$ & 0.82 & 0.99 & 0.72 & 0.43 & -0.01 & 1.00 & & & & & & & & \\
\hline$R c$ & -0.34 & -0.75 & -0.60 & -0.38 & 0.41 & -0.75 & 1.00 & & & & & & & \\
\hline$R e$ & 0.23 & -0.12 & -0.65 & -0.76 & 0.99 & -0.09 & 0.47 & 1.00 & & & & & & \\
\hline$S b$ & 0.02 & 0.32 & 0.78 & 0.91 & -0.69 & 0.31 & -0.43 & -0.77 & 1.00 & & & & & \\
\hline$R u$ & -0.11 & 0.28 & 0.77 & 0.87 & -0.91 & 0.27 & -0.56 & -0.96 & 0.90 & 1.00 & & & & \\
\hline$T c$ & 0.54 & 0.76 & 0.68 & 0.42 & -0.32 & 0.75 & -0.63 & -0.34 & 0.21 & 0.37 & 1.00 & & & \\
\hline$R$ & 0.62 & 0.75 & 0.66 & 0.44 & -0.29 & 0.73 & -0.70 & -0.32 & 0.27 & 0.37 & 0.51 & 1.00 & & \\
\hline$Q p$ & 0.47 & 0.10 & -0.07 & -0.12 & 0.67 & 0.10 & 0.51 & 0.64 & -0.18 & -0.52 & -0.11 & -0.27 & 1.00 & \\
\hline$t p$ & 0.78 & 0.84 & 0.58 & 0.25 & -0.09 & 0.82 & -0.60 & -0.10 & 0.00 & 0.14 & 0.87 & 0.65 & -0.01 & 1.00 \\
\hline
\end{tabular}

\begin{tabular}{|c|c|c|c|c|c|c|c|c|c|c|c|c|c|c|}
\hline & $H$ & $R h$ & $R p$ & $D$ & $R n$ & $C$ & $R f$ & $C f$ & Ls & Cs & $T c$ & $R$ & $Q p$ & $t p$ \\
\hline$H$ & 1.00 & & & & & & & & & & & & & \\
\hline$R h$ & 0.88 & 1.00 & & & & & & & & & & & & \\
\hline$R p$ & 0.88 & 0.96 & 1.00 & & & & & & & & & & & \\
\hline$D$ & 0.36 & 0.65 & 0.69 & 1.00 & & & & & & & & & & \\
\hline$R n$ & 0.95 & 0.95 & 0.97 & 0.62 & 1.00 & & & & & & & & & \\
\hline$C$ & -0.32 & -0.62 & -0.64 & -0.99 & -0.58 & 1.00 & & & & & & & & \\
\hline$R f$ & 0.22 & 0.49 & 0.42 & 0.36 & 0.28 & -0.35 & 1.00 & & & & & & & \\
\hline$C f$ & 0.14 & 0.41 & 0.47 & 0.92 & 0.42 & -0.92 & 0.17 & 1.00 & & & & & & \\
\hline Ls & 0.76 & 0.70 & 0.67 & 0.53 & 0.77 & -0.55 & 0.07 & 0.44 & 1.00 & & & & & \\
\hline Cs & 0.90 & 0.99 & 0.98 & 0.67 & 0.97 & -0.63 & 0.45 & 0.45 & 0.71 & 1.00 & & & & \\
\hline$T c$ & -0.19 & -0.43 & -0.38 & -0.70 & -0.31 & 0.73 & -0.63 & -0.57 & -0.40 & -0.39 & 1.00 & & & \\
\hline$R$ & -0.29 & -0.59 & -0.59 & -0.73 & -0.49 & 0.72 & -0.66 & -0.67 & -0.23 & -0.63 & 0.51 & 1.00 & & \\
\hline$Q p$ & -0.18 & -0.10 & -0.23 & -0.34 & -0.30 & 0.32 & 0.64 & -0.40 & -0.35 & -0.13 & -0.11 & -0.27 & 1.00 & \\
\hline$t p$ & 0.01 & -0.27 & -0.30 & -0.79 & -0.19 & 0.81 & -0.47 & -0.73 & -0.18 & -0.27 & 0.87 & 0.65 & -0.01 & 1.00 \\
\hline
\end{tabular}


Table D.1. Correlation Matrix for North Region Variables (Continued)

\begin{tabular}{|c|c|c|c|c|c|c|c|c|c|c|c|c|c|c|c|}
\hline & $D A$ & Slope & $C D A$ & $U L C$ & Water & Sinks & $C N$ & $M C h$ & $H K R$ & $G$ & $M$ & $T c$ & $R$ & $Q p$ & $t p$ \\
\hline$D A$ & 1.00 & & & & & & & & & & & & & & \\
\hline Slope & -0.49 & 1.00 & & & & & & & & & & & & & \\
\hline$C D A$ & 1.00 & -0.52 & 1.00 & & & & & & & & & & & & \\
\hline$U L C$ & -0.28 & 0.29 & -0.28 & 1.00 & & & & & & & & & & & \\
\hline Water & -0.15 & 0.82 & -0.18 & -0.20 & 1.00 & & & & & & & & & & \\
\hline Sinks & 0.21 & -0.38 & 0.20 & -0.50 & -0.09 & 1.00 & & & & & & & & & \\
\hline$C N$ & 0.09 & -0.36 & 0.10 & 0.27 & -0.49 & 0.26 & 1.00 & & & & & & & & \\
\hline$M C h$ & 0.71 & -0.57 & 0.73 & -0.39 & -0.21 & -0.03 & 0.04 & 1.00 & & & & & & & \\
\hline$H K R$ & 0.82 & -0.75 & 0.84 & -0.27 & -0.47 & 0.26 & -0.04 & 0.59 & 1.00 & & & & & & \\
\hline$G$ & 0.48 & -0.68 & 0.51 & -0.29 & -0.42 & -0.06 & 0.03 & 0.92 & 0.54 & 1.00 & & & & & \\
\hline$M$ & -0.52 & 0.08 & -0.51 & -0.20 & 0.09 & 0.02 & -0.04 & 0.07 & -0.43 & 0.29 & 1.00 & & & & \\
\hline$T c$ & 0.75 & -0.54 & 0.76 & -0.34 & -0.17 & 0.28 & -0.28 & 0.63 & 0.90 & 0.58 & -0.21 & 1.00 & & & \\
\hline$R$ & 0.59 & -0.77 & 0.60 & -0.70 & -0.33 & 0.52 & 0.18 & 0.65 & 0.61 & 0.57 & -0.16 & 0.51 & 1.00 & & \\
\hline$Q p$ & 0.31 & 0.03 & 0.31 & 0.69 & -0.23 & -0.39 & 0.56 & 0.02 & 0.10 & -0.09 & -0.49 & -0.11 & -0.27 & 1.00 & \\
\hline$t p$ & 0.89 & -0.43 & 0.89 & -0.49 & 0.04 & 0.34 & -0.19 & 0.60 & 0.84 & 0.39 & -0.47 & 0.87 & 0.65 & -0.01 & 1 \\
\hline
\end{tabular}


Table D.2. Correlation Matrix for Central Region Variables

\begin{tabular}{|c|c|c|c|c|c|c|c|c|c|c|c|c|c|c|}
\hline & $A w$ & $L p$ & $L b$ & $L c a$ & $R f f$ & $A p$ & $R c$ & $R e$ & $S b$ & $R u$ & $T c$ & $R$ & $Q p$ & $t p$ \\
\hline$A w$ & 1.00 & & & & & & & & & & & & & \\
\hline$L p$ & 0.94 & 1.00 & & & & & & & & & & & & \\
\hline$L b$ & 0.75 & 0.87 & 1.00 & & & & & & & & & & & \\
\hline Lca & 0.81 & 0.91 & 0.89 & 1.00 & & & & & & & & & & \\
\hline$R f f$ & -0.05 & -0.16 & -0.55 & -0.27 & 1.00 & & & & & & & & & \\
\hline$A p$ & 0.92 & 0.98 & 0.82 & 0.87 & -0.18 & 1.00 & & & & & & & & \\
\hline$R c$ & -0.40 & -0.68 & -0.76 & -0.68 & 0.44 & -0.68 & 1.00 & & & & & & & \\
\hline$R e$ & 0.03 & -0.12 & -0.53 & -0.24 & 0.99 & -0.13 & 0.48 & 1.00 & & & & & & \\
\hline$S b$ & -0.14 & 0.09 & 0.50 & 0.30 & -0.77 & 0.07 & -0.57 & -0.84 & 1.00 & & & & & \\
\hline$R u$ & -0.21 & 0.01 & 0.45 & 0.14 & -0.87 & -0.01 & -0.55 & -0.94 & 0.91 & 1.00 & & & & \\
\hline$T c$ & 0.15 & 0.12 & 0.38 & 0.02 & -0.31 & 0.03 & -0.16 & -0.35 & 0.27 & 0.45 & 1.00 & & & \\
\hline$R$ & 0.52 & 0.52 & 0.57 & 0.28 & -0.27 & 0.46 & -0.40 & -0.26 & 0.02 & 0.24 & 0.74 & 1.00 & & \\
\hline$Q p$ & 0.38 & 0.32 & 0.29 & 0.54 & 0.09 & 0.26 & 0.11 & 0.13 & 0.07 & -0.25 & -0.28 & -0.41 & 1.00 & \\
\hline$t p$ & 0.29 & 0.37 & 0.39 & 0.12 & -0.19 & 0.35 & -0.50 & -0.21 & 0.02 & 0.30 & 0.65 & 0.77 & -0.56 & 1.00 \\
\hline
\end{tabular}

\begin{tabular}{|c|c|c|c|c|c|c|c|c|c|c|c|c|c|c|}
\hline & $H$ & $R h$ & $R p$ & $D$ & $R n$ & $C$ & $R f$ & $C f$ & $L s$ & $C s$ & $T c$ & $R$ & $Q p$ & $t p$ \\
\hline$H$ & 1.00 & & & & & & & & & & & & & \\
\hline$R h$ & 0.34 & 1.00 & & & & & & & & & & & & \\
\hline$R p$ & 0.30 & 0.79 & 1.00 & & & & & & & & & & & \\
\hline$D$ & -0.24 & 0.55 & 0.82 & 1.00 & & & & & & & & & & \\
\hline$R n$ & 0.58 & 0.73 & 0.90 & 0.64 & 1.00 & & & & & & & & & \\
\hline$C$ & 0.20 & -0.54 & -0.73 & -0.94 & -0.63 & 1.00 & & & & & & & & \\
\hline$R f$ & 0.06 & 0.55 & 0.42 & 0.36 & 0.34 & -0.40 & 1.00 & & & & & & & \\
\hline$C f$ & -0.24 & 0.54 & 0.82 & 0.96 & 0.58 & -0.80 & 0.26 & 1.00 & & & & & & \\
\hline Ls & 0.51 & 0.76 & 0.70 & 0.38 & 0.66 & -0.21 & 0.25 & 0.50 & 1.00 & & & & & \\
\hline$C s$ & 0.38 & 0.61 & 0.84 & 0.69 & 0.83 & -0.56 & 0.20 & 0.72 & 0.78 & 1.00 & & & & \\
\hline$T c$ & -0.16 & -0.52 & -0.41 & -0.42 & -0.49 & 0.37 & -0.54 & -0.39 & -0.59 & -0.55 & 1.00 & & & \\
\hline$R$ & -0.23 & -0.71 & -0.71 & -0.68 & -0.73 & 0.72 & -0.75 & -0.55 & -0.53 & -0.68 & 0.74 & 1.00 & & \\
\hline$Q p$ & 0.54 & 0.08 & -0.02 & -0.30 & 0.16 & 0.20 & 0.60 & -0.40 & 0.07 & -0.02 & -0.28 & -0.41 & 1.00 & \\
\hline$t p$ & -0.26 & -0.55 & -0.60 & -0.48 & -0.59 & 0.49 & -0.82 & -0.41 & -0.43 & -0.38 & 0.65 & 0.77 & -0.56 & 1.00 \\
\hline
\end{tabular}


Table D.2. Correlation Matirix for Central Region (Continued)

\begin{tabular}{|c|c|c|c|c|c|c|c|c|c|c|c|c|c|c|c|}
\hline & $D A$ & Slope & $C D A$ & $U L C$ & Water & Sinks & $C N$ & $M C h$ & $H K R$ & $G$ & $M$ & $T c$ & $R$ & $Q p$ & $t p$ \\
\hline$D A$ & 1.00 & & & & & & & & & & & & & & \\
\hline Slope & -0.69 & 1.00 & & & & & & & & & & & & & \\
\hline$C D A$ & 1.00 & -0.69 & 1.00 & & & & & & & & & & & & \\
\hline$U L C$ & -0.31 & 0.47 & -0.31 & 1.00 & & & & & & & & & & & \\
\hline Water & 0.38 & -0.72 & 0.38 & -0.26 & 1.00 & & & & & & & & & & \\
\hline Sinks & 0.55 & -0.35 & 0.55 & 0.11 & -0.07 & 1.00 & & & & & & & & & \\
\hline$C N$ & 0.14 & -0.46 & 0.14 & -0.49 & 0.27 & 0.46 & 1.00 & & & & & & & & \\
\hline$M C h$ & 0.86 & -0.74 & 0.86 & -0.24 & 0.58 & 0.28 & -0.08 & 1.00 & & & & & & & \\
\hline$H K R$ & 0.67 & -0.78 & 0.67 & -0.40 & 0.88 & 0.18 & 0.35 & 0.72 & 1.00 & & & & & & \\
\hline$G$ & 0.78 & -0.77 & 0.78 & -0.18 & 0.73 & 0.40 & 0.17 & 0.92 & 0.84 & 1.00 & & & & & \\
\hline$M$ & -0.73 & 0.76 & -0.73 & 0.05 & -0.49 & -0.50 & -0.03 & -0.74 & -0.56 & -0.69 & 1.00 & & & & \\
\hline$T c$ & 0.16 & -0.55 & 0.16 & -0.38 & 0.33 & -0.23 & 0.21 & 0.34 & 0.29 & 0.29 & -0.07 & 1.00 & & & \\
\hline$R$ & 0.52 & -0.80 & 0.52 & -0.53 & 0.65 & 0.01 & 0.32 & 0.68 & 0.74 & 0.68 & -0.33 & 0.74 & 1.00 & & \\
\hline$Q p$ & 0.38 & 0.01 & 0.38 & 0.45 & -0.11 & 0.44 & -0.31 & 0.28 & -0.03 & 0.25 & -0.49 & -0.28 & -0.41 & 1.00 & \\
\hline$t p$ & 0.31 & -0.60 & 0.31 & -0.44 & 0.45 & -0.11 & 0.28 & 0.40 & 0.37 & 0.31 & -0.18 & 0.65 & 0.77 & -0.56 & 1.00 \\
\hline
\end{tabular}


Table D.3. Correlation Matrix for South Region

\begin{tabular}{|c|c|c|c|c|c|c|c|c|c|c|c|c|c|c|}
\hline & $A w$ & $L p$ & $L b$ & $L c a$ & Rff & $A p$ & $R c$ & $R e$ & $S b$ & $R u$ & $T c$ & $R$ & $Q p$ & $t p$ \\
\hline$A w$ & 1.00 & & & & & & & & & & & & & \\
\hline$L p$ & 0.74 & 1.00 & & & & & & & & & & & & \\
\hline$L b$ & 0.60 & 0.98 & 1.00 & & & & & & & & & & & \\
\hline$L c a$ & 0.71 & 0.94 & 0.93 & 1.00 & & & & & & & & & & \\
\hline$R f f$ & -0.03 & -0.67 & -0.80 & -0.66 & 1.00 & & & & & & & & & \\
\hline$A p$ & 0.74 & 1.00 & 0.96 & 0.91 & -0.64 & 1.00 & & & & & & & & \\
\hline$R c$ & 0.16 & -0.54 & -0.67 & -0.51 & 0.95 & -0.53 & 1.00 & & & & & & & \\
\hline$R e$ & 0.04 & -0.62 & -0.76 & -0.62 & 1.00 & -0.59 & 0.97 & 1.00 & & & & & & \\
\hline$S b$ & -0.35 & 0.29 & 0.47 & 0.38 & -0.87 & 0.25 & -0.91 & -0.90 & 1.00 & & & & & \\
\hline$R u$ & -0.17 & 0.52 & 0.67 & 0.53 & -0.97 & 0.49 & -0.98 & -0.99 & 0.95 & 1.00 & & & & \\
\hline$T c$ & 0.12 & 0.24 & 0.30 & 0.35 & -0.30 & 0.21 & -0.16 & -0.28 & 0.19 & 0.23 & 1.00 & & & \\
\hline$R$ & 0.15 & 0.16 & 0.12 & 0.19 & -0.12 & 0.16 & -0.13 & -0.10 & 0.08 & 0.06 & 0.07 & 1.00 & & \\
\hline$Q p$ & 0.85 & 0.68 & 0.56 & 0.58 & -0.04 & 0.68 & 0.08 & 0.01 & -0.28 & -0.10 & -0.26 & -0.12 & 1.00 & \\
\hline$t p$ & 0.32 & 0.41 & 0.33 & 0.37 & -0.18 & 0.44 & -0.24 & -0.17 & -0.01 & 0.14 & 0.02 & 0.68 & 0.16 & 1.00 \\
\hline
\end{tabular}

\begin{tabular}{|c|c|c|c|c|c|c|c|c|c|c|c|c|c|c|}
\hline & $H$ & $R h$ & $R p$ & $D$ & $R n$ & $C$ & $R f$ & $C f$ & $L s$ & Cs & $T c$ & $R$ & $Q p$ & $t p$ \\
\hline$H$ & 1.00 & & & & & & & & & & & & & \\
\hline$R h$ & 0.66 & 1.00 & & & & & & & & & & & & \\
\hline$R p$ & 0.73 & 0.99 & 1.00 & & & & & & & & & & & \\
\hline$D$ & -0.42 & 0.26 & 0.21 & 1.00 & & & & & & & & & & \\
\hline$R n$ & 0.74 & 0.87 & 0.91 & 0.30 & 1.00 & & & & & & & & & \\
\hline$C$ & 0.47 & -0.21 & -0.15 & -0.99 & -0.24 & 1.00 & & & & & & & & \\
\hline$R f$ & 0.54 & 0.61 & 0.61 & -0.03 & 0.57 & 0.06 & 1.00 & & & & & & & \\
\hline$C f$ & -0.37 & 0.31 & 0.23 & 0.80 & 0.18 & -0.80 & -0.31 & 1.00 & & & & & & \\
\hline Ls & 0.84 & 0.82 & 0.86 & 0.01 & 0.89 & 0.06 & 0.52 & 0.02 & 1.00 & & & & & \\
\hline$C s$ & 0.56 & 0.83 & 0.85 & 0.47 & 0.93 & -0.42 & 0.56 & 0.29 & 0.72 & 1.00 & & & & \\
\hline$T c$ & -0.24 & -0.42 & -0.38 & -0.24 & -0.40 & 0.22 & -0.14 & -0.22 & -0.46 & -0.31 & 1.00 & & & \\
\hline$R$ & -0.38 & -0.37 & -0.40 & 0.22 & -0.21 & -0.25 & 0.28 & -0.16 & -0.39 & -0.10 & 0.07 & 1.00 & & \\
\hline$Q p$ & 0.53 & -0.09 & -0.06 & -0.85 & -0.07 & 0.83 & 0.15 & -0.74 & 0.21 & -0.27 & -0.26 & -0.12 & 1.00 & \\
\hline$t p$ & -0.25 & -0.39 & -0.44 & -0.11 & -0.30 & 0.08 & 0.06 & -0.16 & -0.18 & -0.43 & 0.02 & 0.68 & 0.16 & 1.00 \\
\hline
\end{tabular}


Table D.3. Correlation Matrix for South Region (Continued)

\begin{tabular}{|c|c|c|c|c|c|c|c|c|c|c|c|c|c|c|c|}
\hline & $D A$ & Slope & $C D A$ & $U L C$ & Water & Sinks & $C N$ & $M C h$ & $H K R$ & $G$ & $M$ & $T c$ & $R$ & $Q p$ & $t p$ \\
\hline$D A$ & 1.00 & & & & & & & & & & & & & & \\
\hline Slope & -0.42 & 1.00 & & & & & & & & & & & & & \\
\hline$C D A$ & 1.00 & -0.42 & 1.00 & & & & & & & & & & & & \\
\hline$U L C$ & -0.11 & -0.23 & -0.11 & 1.00 & & & & & & & & & & & \\
\hline Water & -0.30 & -0.50 & -0.30 & 0.39 & 1.00 & & & & & & & & & & \\
\hline Sinks & 0.13 & -0.61 & 0.13 & 0.46 & 0.83 & 1.00 & & & & & & & & & \\
\hline$C N$ & 0.34 & -0.75 & 0.34 & -0.08 & 0.35 & 0.49 & 1.00 & & & & & & & & \\
\hline$M C h$ & 0.70 & -0.53 & 0.70 & 0.46 & -0.01 & 0.40 & 0.39 & 1.00 & & & & & & & \\
\hline$H K R$ & 0.87 & -0.71 & 0.87 & 0.02 & 0.06 & 0.36 & 0.60 & 0.68 & 1.00 & & & & & & \\
\hline$G$ & 0.54 & -0.80 & 0.54 & 0.43 & 0.50 & 0.75 & 0.67 & 0.81 & 0.77 & 1.00 & & & & & \\
\hline$M$ & -0.62 & -0.10 & -0.62 & 0.45 & 0.69 & 0.48 & 0.18 & 0.02 & -0.36 & 0.28 & 1.00 & & & & \\
\hline$T c$ & 0.17 & -0.34 & 0.17 & 0.51 & 0.38 & 0.53 & 0.28 & 0.27 & 0.23 & 0.38 & 0.06 & 1.00 & & & \\
\hline$R$ & 0.16 & -0.05 & 0.16 & -0.21 & 0.31 & 0.58 & 0.17 & 0.00 & 0.12 & 0.19 & 0.06 & 0.07 & 1.00 & & \\
\hline$Q p$ & 0.83 & -0.39 & 0.83 & -0.17 & -0.44 & -0.15 & 0.21 & 0.67 & 0.72 & 0.41 & -0.53 & -0.26 & -0.12 & 1.00 & \\
\hline$t p$ & 0.34 & -0.39 & 0.34 & 0.15 & 0.44 & 0.66 & 0.16 & 0.23 & 0.48 & 0.48 & -0.02 & 0.02 & 0.68 & 0.16 & 1.00 \\
\hline
\end{tabular}




\section{Appendix E}

Table E.1. Ranges of geomorphologic parameters for use in regression equations

\begin{tabular}{|c|c|c|c|c|c|}
\hline & & & & Range & \\
\hline Region & Dependent & Independent & Units & Min & Max \\
\hline \multirow[t]{7}{*}{ North } & $\mathrm{R}$ & & & & \\
\hline & & ULC & $\%$ & 0.01 & 35.4 \\
\hline & & $\mathrm{C}_{\mathrm{f}}$ & \#streams $/ \mathrm{km}^{2}$ & 0.5 & 1.99 \\
\hline & $t_{c}$ & & & & \\
\hline & & CDA & $\mathrm{mi}^{2}$ & 9.3 & 38.1 \\
\hline & & $\mathrm{C}_{\mathrm{f}}$ & \#streams $/ \mathrm{km}^{2}$ & 0.5 & 1.99 \\
\hline & & G & & 122647 & 461578 \\
\hline \multirow[t]{7}{*}{ Central } & $\mathrm{R}$ & & & & \\
\hline & & $\mathrm{R}_{\mathrm{f}}$ & $\mathrm{m} / \mathrm{m}$ & 0.699 & 1.12 \\
\hline & & Slope & $\mathrm{ft} / \mathrm{mi}$ & 4.35 & 22.8 \\
\hline & $t_{c}$ & & & & \\
\hline & & $\mathrm{L}_{\mathrm{s}}$ & $\mathrm{m} / \mathrm{m}$ & 0.0149 & 0.0967 \\
\hline & & $\mathrm{H}$ & $\mathrm{m}$ & 19.88 & 69.43 \\
\hline & & ULC & $\%$ & 0.12 & 83 \\
\hline
\end{tabular}

\begin{tabular}{|c|c|c|c|c|c|}
\hline \multirow[t]{9}{*}{ South } & $\mathrm{R}$ & & & & \\
\hline & & $\mathrm{L}_{\mathrm{ca}}$ & $\mathrm{m}$ & 3283 & 7462 \\
\hline & & $\mathrm{C}$ & $\mathrm{m}$ & 686.7 & 1107 \\
\hline & & $\mathrm{Rf}$ & $\mathrm{m} / \mathrm{m}$ & 0.662 & 1.194 \\
\hline & $t_{c}$ & & & & \\
\hline & & ULC & $\%$ & 0.08 & 7.96 \\
\hline & & $\mathrm{CN}$ & & 63 & 79 \\
\hline & & $\mathrm{R}_{\mathrm{f}}$ & $\mathrm{m} / \mathrm{m}$ & 0.662 & 1.194 \\
\hline & & $\mathrm{H}$ & $\mathrm{m}$ & 53.14 & 109.34 \\
\hline \multirow[t]{7}{*}{ Statewide } & $\mathrm{R}$ & & & & \\
\hline & & Slope & $\mathrm{ft} / \mathrm{mi}$ & 3 & 44.6 \\
\hline & & Sinks & $\%$ & 0.82 & 14.72 \\
\hline & $t_{c}$ & & & & \\
\hline & & $\mathrm{L}_{\mathrm{b}}$ & $\mathrm{m}$ & 5520 & 23155 \\
\hline & & $\mathrm{L}_{\mathrm{s}}$ & $\mathrm{m} / \mathrm{m}$ & 0.0149 & 0.411 \\
\hline & & Water & $\%$ & 0.06 & 13 \\
\hline
\end{tabular}




\section{Appendix F}

Table F.1. Precipitation Depth and Duration

\begin{tabular}{|c|c|c|c|c|c|c|}
\hline Station Name & $\begin{array}{l}\text { Station } \\
\text { No. }\end{array}$ & Region & $\begin{array}{c}\mathrm{P} \\
\text { (in) }\end{array}$ & Start & End & $\begin{array}{l}\text { Duration } \\
\text { (hrs:min) }\end{array}$ \\
\hline \multirow[t]{3}{*}{ WEESAU CREEK } & 3328430 & North & 0.6 & $00: 15$ & 1:00 & $12: 45$ \\
\hline & & & 4.9 & $5: 00$ & $7: 45$ & $2: 45$ \\
\hline & & & 1.5 & $15: 15$ & $3: 30$ & $12: 15$ \\
\hline \multirow[t]{3}{*}{ GALENA RIVER } & 4096100 & North & 1.1 & 14:00 & $17: 45$ & $3: 45$ \\
\hline & & & 2.5 & $12: 45$ & $13: 30$ & $12: 45$ \\
\hline & & & 1.6 & $10: 15$ & $24: 00$ & $1: 45$ \\
\hline \multirow[t]{3}{*}{ FORKER CREEK } & 4100252 & North & 1.0 & $00: 30$ & $19: 45$ & $7: 15$ \\
\hline & & & 1.4 & $15: 45$ & $4: 15$ & $8: 30$ \\
\hline & & & 1.6 & $10: 15$ & $24: 00$ & $1: 45$ \\
\hline \multirow[t]{3}{*}{ RIMMELL BRANCH } & 4100295 & North & 1.2 & $00: 15$ & $7: 30$ & $7: 15$ \\
\hline & & & 1.6 & $00: 15$ & $14: 45$ & $2: 30$ \\
\hline & & & 1.4 & $6: 00$ & $12: 45$ & $6: 45$ \\
\hline \multirow[t]{3}{*}{ SOLOMON CREEK } & 4100377 & North & 3.1 & $13: 45$ & $7: 15$ & $12: 30$ \\
\hline & & & 1.2 & $21: 15$ & 4:00 & $6: 45$ \\
\hline & & & 1.9 & $4: 15$ & $17: 45$ & $1: 30$ \\
\hline \multirow[t]{3}{*}{ FISH CREEK } & 4177720 & North & 1.1 & $00: 15$ & 8:00 & $7: 45$ \\
\hline & & & 1.6 & $14: 45$ & $00: 15$ & $9: 30$ \\
\hline & & & 2.9 & $00: 45$ & $8: 00$ & $7: 15$ \\
\hline \multirow[t]{3}{*}{ SPY RUN CREEK } & 4182810 & North & 0.9 & $14: 00$ & 24:00 & $10: 00$ \\
\hline & & & 1.3 & $16: 45$ & 22:00 & $5: 15$ \\
\hline & & & 1.6 & $1: 15$ & $12: 45$ & $11: 30$ \\
\hline \multirow[t]{3}{*}{ COBB DITCH } & 5517890 & North & 1.4 & 4:00 & $6: 45$ & $2: 45$ \\
\hline & & & 1.9 & $10: 15$ & 24:00 & $1: 45$ \\
\hline & & & 1.0 & $6: 30$ & $15: 45$ & $9: 15$ \\
\hline \multirow[t]{3}{*}{ IROQUOIS RIVER } & 5521000 & North & 2.0 & $3: 15$ & 19:00 & $3: 45$ \\
\hline & & & 0.8 & $00: 45$ & $19: 45$ & 7:00 \\
\hline & & & 1.0 & $6: 30$ & $22: 45$ & 4:15 \\
\hline \multirow[t]{3}{*}{ WHITEWATER RIVER } & 3274650 & Central & 0.9 & $21: 45$ & $23: 45$ & $2: 00$ \\
\hline & & & 0.6 & $1: 30$ & $2: 45$ & $1: 15$ \\
\hline & & & 0.7 & $22: 00$ & $22: 45$ & $12: 45$ \\
\hline \multirow[t]{3}{*}{ LITTLE MISSISSINEWA RIVER } & 3325311 & Central & 1.1 & $10: 30$ & $4: 15$ & $5: 45$ \\
\hline & & & 2.2 & $2: 30$ & 22:00 & $7: 30$ \\
\hline & & & 0.9 & $00: 45$ & $4: 30$ & $3: 45$ \\
\hline \multirow[t]{3}{*}{ BIG LICK CREEK } & 3326070 & Central & 2.0 & $9: 15$ & $12: 45$ & $3: 30$ \\
\hline & & & 1.3 & $6: 00$ & $15: 45$ & $9: 45$ \\
\hline & & & 0.8 & $7: 45$ & 2:00 & $6: 15$ \\
\hline \multirow[t]{3}{*}{ KOKOMO CREEK } & 3333600 & Central & 1.2 & $1: 15$ & 23:00 & $9: 45$ \\
\hline & & & 1.1 & $12: 15$ & $14: 30$ & $2: 15$ \\
\hline & & & 1.3 & 23:15 & $3: 45$ & 4:30 \\
\hline \multirow[t]{3}{*}{ BUCK CREEK } & 3347500 & Central & 0.8 & $16: 15$ & $22: 30$ & 6:15:00 AM \\
\hline & & & 2.3 & $8: 15$ & $24: 00$ & $3: 45: 00 \mathrm{PM}$ \\
\hline & & & 1.0 & $23: 45$ & $2: 45$ & 3:00:00 AM \\
\hline
\end{tabular}


Table F.1. Precipitation Depth and Duration (Continued)

\begin{tabular}{|c|c|c|c|c|c|c|}
\hline Station Name & Station No. & Region & $\mathrm{P}$ (in) & Start & End & Duration (hrs:min) \\
\hline \multirow[t]{3}{*}{ CROOKED CREEK } & 3351310 & Central & 1.5 & $12: 15$ & 19:30 & $7: 15$ \\
\hline & & & 0.4 & $15: 30$ & $18: 15$ & $2: 45$ \\
\hline & & & 1.1 & $00: 30$ & $5: 00$ & $4: 30$ \\
\hline \multirow[t]{3}{*}{ PLEASANT RUN } & 3353120 & Central & 0.5 & $1: 45$ & $5: 45$ & 4:00 \\
\hline & & & 1.7 & $1: 15$ & $2: 15$ & 1:00 \\
\hline & & & 1.4 & $00: 45$ & $1: 45$ & 1:00 \\
\hline \multirow[t]{3}{*}{ LITTLE BUCK CREEK } & 3353637 & Central & 0.9 & $17: 30$ & $23: 45$ & $6: 15$ \\
\hline & & & 0.8 & $21: 30$ & $1: 15$ & $3: 45$ \\
\hline & & & 0.5 & $00: 15$ & $3: 15$ & 3:00 \\
\hline \multirow[t]{3}{*}{ WEST FORK WHITE LICK CRK } & 3353700 & Central & 0.9 & $17: 30$ & $23: 45$ & $6: 15$ \\
\hline & & & 1.5 & $1: 00$ & $3: 30$ & $2: 30$ \\
\hline & & & 1.8 & $5: 45$ & 19:30 & $1: 45$ \\
\hline \multirow[t]{3}{*}{ PLUM CREEK } & 3357350 & Central & 1.2 & $15: 45$ & $23: 15$ & $7: 30$ \\
\hline & & & 1.0 & $6: 15$ & $7: 45$ & $1: 30$ \\
\hline & & & 0.8 & 18:00 & $18: 45$ & $12: 45$ \\
\hline \multirow[t]{3}{*}{ LITTLE INDIAN CREEK } & 3302300 & South & 1.3 & $5: 30$ & 14:00 & $8: 30$ \\
\hline & & & 1.6 & 19:30 & $4: 30$ & 9:00 \\
\hline & & & 2.0 & $00: 15$ & 14:30 & $2: 15$ \\
\hline \multirow[t]{3}{*}{ WEST FORK BLUE RIVER } & 3302680 & South & 1.2 & 11:00 & $3: 00$ & 4:00 \\
\hline & & & 1.0 & $5: 15$ & 10:45 & $5: 30$ \\
\hline & & & 0.6 & $17: 15$ & $1: 00$ & $7: 15$ \\
\hline \multirow[t]{3}{*}{ CROOKED CREEK } & 3303400 & South & 0.7 & 23:00 & $3: 00$ & 4:00 \\
\hline & & & 1.0 & $5: 15$ & $11: 30$ & $6: 15$ \\
\hline & & & 1.1 & 19:30 & 10:00 & $2: 30$ \\
\hline \multirow[t]{3}{*}{ BUSSERON CREEK } & 3342100 & South & 1.8 & $9: 45$ & 19:00 & $9: 15$ \\
\hline & & & 2.1 & $3: 15$ & $20: 15$ & 5:00 \\
\hline & & & 1.6 & $18: 15$ & $23: 15$ & $5: 00$ \\
\hline \multirow[t]{3}{*}{ HARBERTS CREEK } & 3366200 & South & 1.3 & $3: 00$ & 16:00 & 1:00 \\
\hline & & & 1.0 & $5: 15$ & 13:00 & $7: 45$ \\
\hline & & & 0.7 & $4: 00$ & 12:00 & 8:00 \\
\hline \multirow[t]{3}{*}{ BRUSH CREEK } & 3368000 & South & 0.5 & $15: 30$ & $23: 45$ & $8: 15$ \\
\hline & & & 1.0 & $7: 00$ & $13: 30$ & $6: 30$ \\
\hline & & & 1.3 & $6: 30$ & $5: 30$ & 11:00 \\
\hline \multirow[t]{3}{*}{ BACK CREEK } & 3371520 & South & 0.6 & $20: 00$ & $23: 45$ & $3: 45$ \\
\hline & & & 1.2 & $7: 00$ & $12: 15$ & $5: 15$ \\
\hline & & & 1.6 & 1:00 & $4: 45$ & $3: 45$ \\
\hline \multirow[t]{3}{*}{ STEPHENS CREEK } & 3372300 & South & 1.0 & $4: 15$ & 14:45 & $10: 30$ \\
\hline & & & 1.6 & $13: 15$ & $23: 00$ & $9: 45$ \\
\hline & & & 1.9 & $2: 15$ & $18: 15$ & 4:00 \\
\hline \multirow[t]{3}{*}{ PATOKA RIVER } & 3374455 & South & 2.2 & 23:00 & $14: 30$ & $3: 00$ \\
\hline & & & 1.3 & $21: 15$ & $10: 45$ & $12: 30$ \\
\hline & & & 1.4 & $24: 00$ & $21: 15$ & $9: 15$ \\
\hline \multirow[t]{3}{*}{ HALL CREEK } & 3375800 & South & 0.9 & $20: 15$ & $23: 15$ & $3: 00$ \\
\hline & & & 2.0 & 12:00 & $18: 15$ & $6: 15$ \\
\hline & & & 1.1 & $20: 45$ & $8: 15$ & $11: 30$ \\
\hline
\end{tabular}


Appendix G: Link to Tutorials for Measuring Geomorphologic Parameters

The tutorial for extracting geomorphic parameters using GIS is available at the link below:

$\underline{\mathrm{ftp}: / / \mathrm{ftp} . e c n . p u r d u e . e d u / v m e r w a d e / t u t o r i a l / g e o m o r p h . p d f}$ 